\title{
Learning a trade in New Zealand: On and off the job learning in engineering trades
}

\author{
James Cannan BEd, MEd \\ Student Number: 30062828 \\ This thesis is submitted in partial fulfilment \\ of the requirements of the degree of \\ Doctor of Education (EdD)
}

School of Education

Federation University

PO Box 663

University Drive, Mount Helen

Ballarat Victoria 3353

Australia

Submitted in August 2017 


\section{Table of Contents}

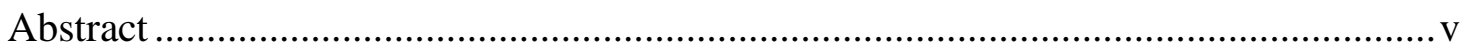

Statement of Authorship and Originality .............................................................. vi

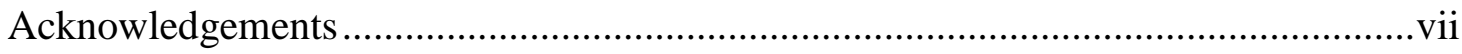

Professional Editorial Assistance...................................................................................

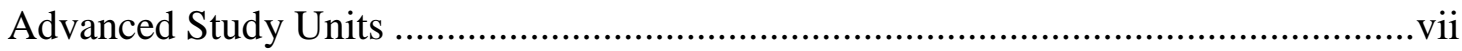

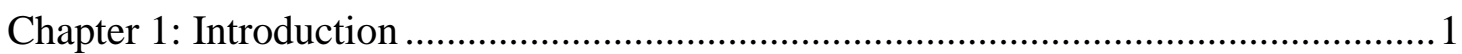

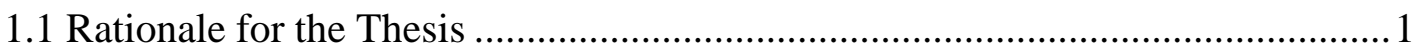

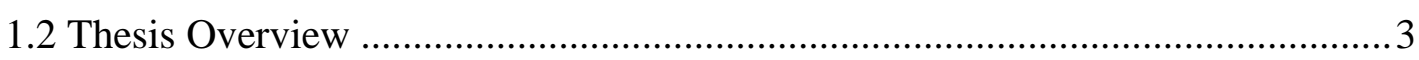

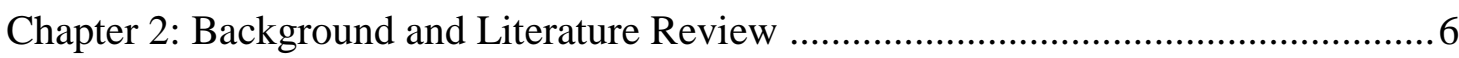

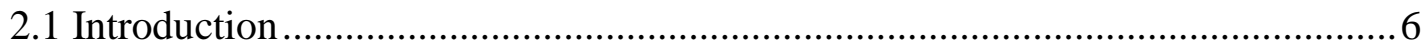

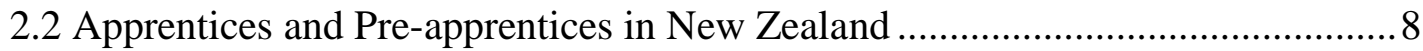

2.3 The History of Vocational Education and Training in New Zealand and a

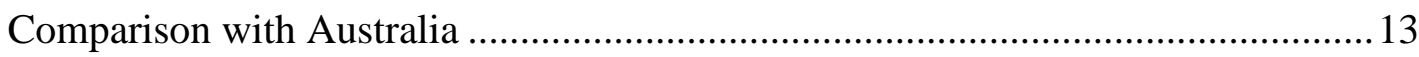

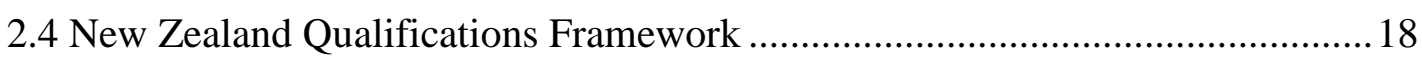

2.5 Apprenticeship Training Overseas and in New Zealand ..................................20

2.6 Pre-apprenticeship Training Overseas and in New Zealand ..............................26

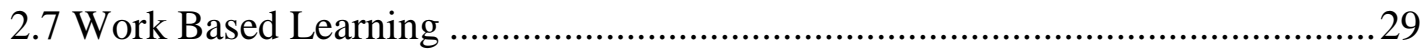

2.8 Assessment Practices for Pre-apprentices and Apprentices .................................36

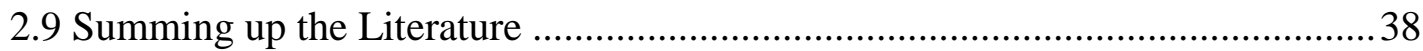

Chapter 3: Research Methodology and Design ........................................................ 41

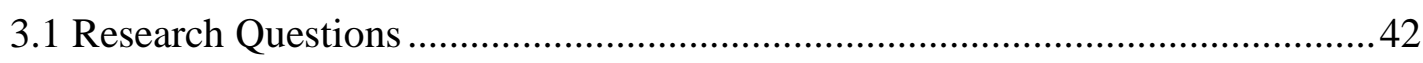

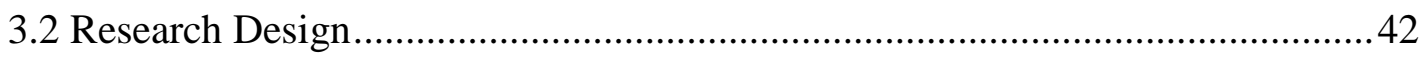

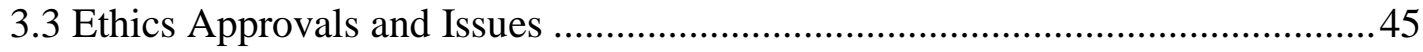

3.4 Research Participants and Sites................................................................... 47

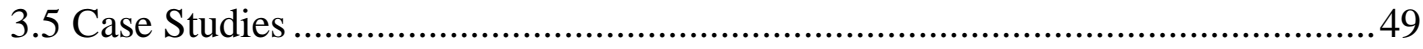

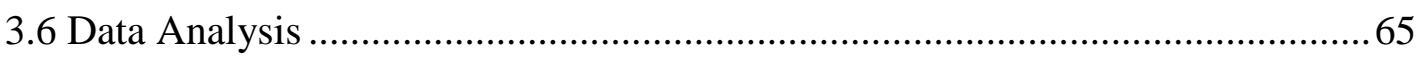

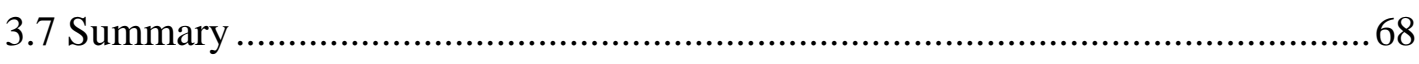

Chapter 4: Findings from Students, Lecturers and Employers ..................................69

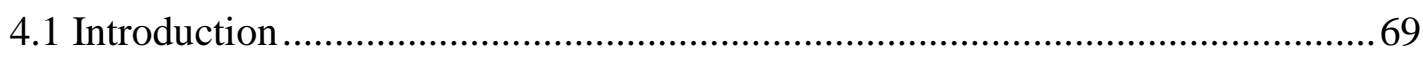

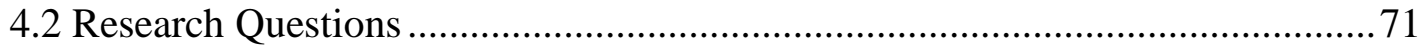

4.3 Findings from the Student Questionnaires .................................................... 71

4.4 Findings from the Pre-apprentice Focus Groups ……........................................ 86 
4.5 Findings from the Apprentice Focus Groups ..................................................98

4.6 Findings from the Interviews with Lecturers .................................................. 108

4.7 Findings from the Interviews with Employers............................................ 122

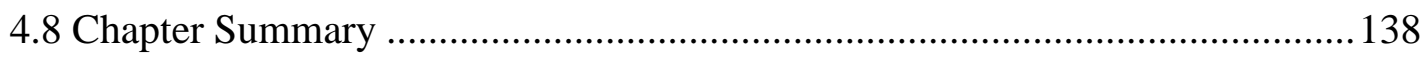

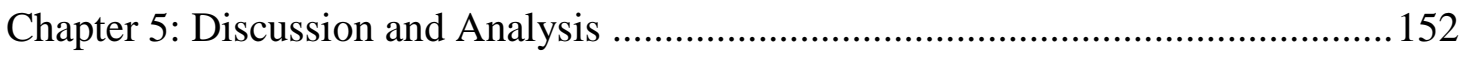

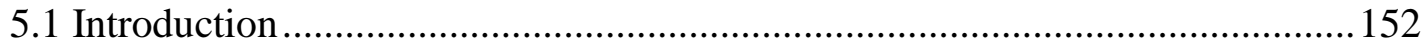

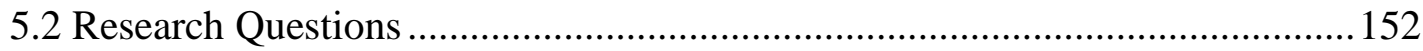

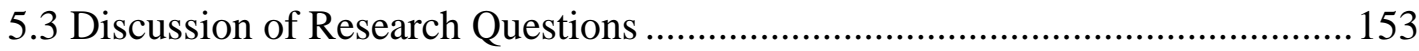

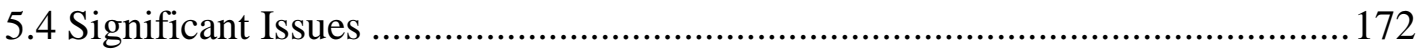

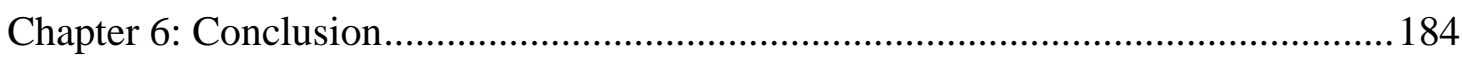

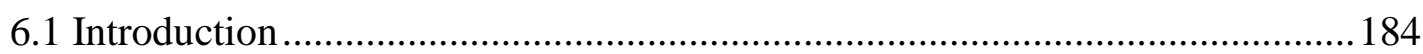

6.2 Summary of Key Points in Relation to the Research Sub-questions ............... 184

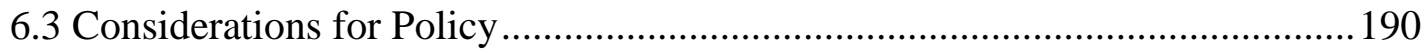

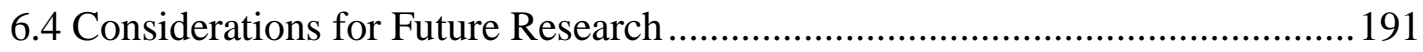

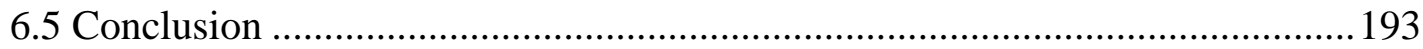

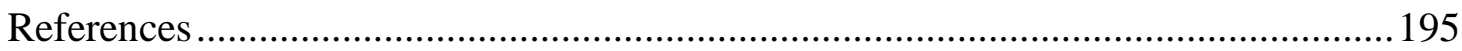

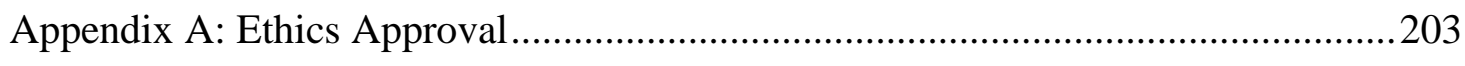

Appendix B: Plain Language Information Statement .............................................211

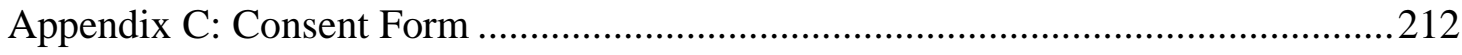

Appendix D: Consent Form for Lecturers ............................................................213

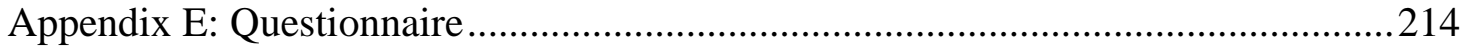

Appendix F: Interview Questions-Apprenticeship/Pre-apprenticeship Training.....215

Appendix G: Interview Questions_Employer/Workplace Supervisor.....................217

Appendix H: Interview Questions_-Staff (Apprenticeships Level 3) .......................218

Appendix I: Interview Questions_-Staff (Pre-apprenticeships) ................................219

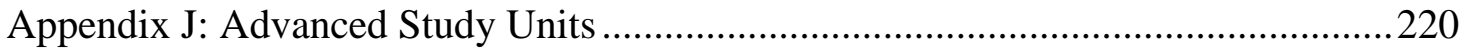




\section{List of Tables}

Table 3.1: List of case studies

Table 3.2: Questionnaire questions for students administered prior to the focus groups

Table 3.3: Focus group interview questions 55

Table 3.4: Advantages of interviews over questionnaires, observations and experiments

Table 3.5: Lecturer information .59

Table 3.6: Summary of interview questions for lecturers. 60

Table 3.7: Employer information. 61

Table 3.8: Summary of interview questions for employers

Table 3.9: Mapping of the student focus groups, lecturer and employer interview questions to the research sub-questions

Table 3.10: Example of a theme table 67

Table 4.1: Case study list .70

Table 4.2: Background demographic data for pre-apprentice students:

Refrigeration/air-conditioning/electrical.

Table 4.3: Participants' questionnaire summary for pre-apprentice students:

Refrigeration/air-conditioning/electrical..... 74

Table 4.4: Background demographic data for pre-apprentice students: Automotive .. 77

Table 4.5: Participants' questionnaire summary for pre-apprentice students:

Automotive .78

Table 4.6: Background demographic data for apprentice students: Refrigeration/airconditioning/electrical 80

Table 4.7: Participants' questionnaire summary for apprentice students:

Refrigeration/air-conditioning/electrical. 81

Table 4.8: Background demographic data for apprentice students: Automotive.

Table 4.9: Participants' questionnaire summary for apprentice students: Automotive84

Table 4.10: Lecturers 109

Table 4.11: Employers 123 


\section{List of Figures}

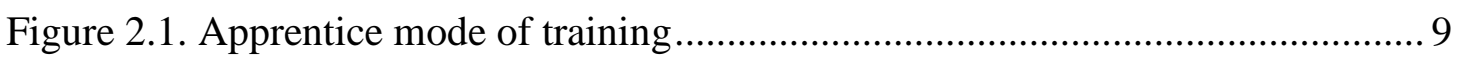

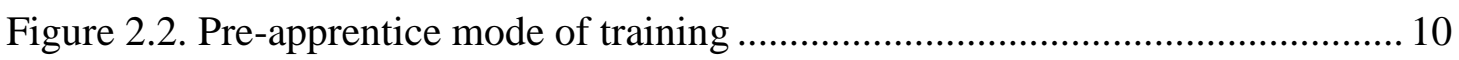

Figure 2.3. Workplace interaction to assessment through industry training managers,

assessors, trainers, moderators, learners and apprentices 12

Figure 5.1. Modes of training with challenges to learning and assessment resulting in

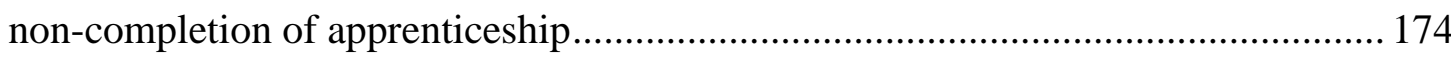

Figure 5.2 Modes of training: hybrid apprentice completing an apprenticeship....... 182 


\begin{abstract}
The engineering trades selected for this study were specifically in the automotive and refrigeration/air-conditioning/electrical disciplines, as they are typical of the engineering discipline trade groups studying at institutes of technology and workplaces as apprentices. This research focused on two trade occupations within the engineering industry and investigated differences between pre-apprentice and apprentice experiences in skills and knowledge acquisition and assessment whilst learning on and off the job; that is, studying vocational education at institutes of technology and engaging in practical activities at the workplace.
\end{abstract}

New Zealand has faced dramatic changes in tertiary education over the past 20 years, particularly in the vocational education and training (VET) sector. As a result of these changes there has been a substantial increase in participation in education and training. There is now a far wider range of courses to cater for the needs of learners in the vocational sector as the New Zealand population grows, along with the engineering trade opportunities that are currently available in the workplace.

A qualitative research approach was used including interviews, focus groups and questionnaires. The project consisted of case studies based around cohorts of apprentices and pre-apprentices. Lecturers and employers were also included. The findings of the study will inform discussions on the ways in which learning prior to and in the workplace might be more effectively facilitated and managed in the future. It also raises questions about the effectiveness and quality of current training and assessment of engineering trade programs of study within New Zealand, as well as issues in apprenticeships and attrition within specific trades. 


\section{Statement of Authorship and Originality}

Except where explicit reference is made in the text of the thesis, this thesis contains no material published elsewhere or extracted in whole or in part from a thesis by which I have qualified for or been awarded another degree or diploma. No other person's work has been relied upon or used without due acknowledgement in the main text and references of the thesis. No editorial assistance has been received in the production of the thesis without due acknowledgement. Except where duly referred to, the thesis does not include material with copyright provisions or requiring copyright approvals.

Signed: 42 bamam

Dated: 7-08-2017

James J Cannan

Candidate
Signed:

Dated:

Professor Erica Smith

Principal Supervisor 


\section{Acknowledgements}

I would like to thank all the pre-apprentices and apprentices, lecturers and employers who participated in this study and gave up their time. Without them this study would not have been possible.

Very special thanks to my supervisors, Professor Erica Smith and Associate Professor Annette Foley, for their valuable support, encouragement and patience. They have kept me on track over the past few years to complete this thesis.

I would also like to thank my wife for supporting me over the period of this research and at times having to go it alone with household duties. Without her support it would be doubtful if I would have been able to complete this project.

My thanks also go to all my work colleagues who have been very supportive and helpful throughout this research.

\section{Professional Editorial Assistance}

Paid editorial assistance was obtained from Kim Woodland Editing in accordance with the Federation University guidelines. Permission was obtained before obtaining the editorial assistance. Services provided were limited to copyediting, proofreading and formatting.

\section{Advanced Study Units}

Prior to commencing this study all the required advanced study units were completed (please refer to Appendix J). 


\section{Chapter 1: Introduction}

Chapter 1 provides an overview of this research study which examines trade training in refrigeration/air-conditioning/electrical and automotive engineering in New Zealand. The study investigates the relative effectiveness of features of preapprenticeship and apprenticeship modes of delivery in engineering trades. A description of the research is provided, detailing the research objectives, the main research question and associated sub-questions. The chapter concludes with a description of how the thesis is structured from Chapter 1 to Chapter 6.

\subsection{Rationale for the Thesis}

There have been significant challenges to vocational education and training (VET) in New Zealand over the past few years, particularly in the trades sector, as the number of school leavers entering trades has been declining (Maurice-Takerei, 2015). Successive governments in New Zealand have realised the importance of vocational education and trades training, and have tried to address the decline in apprenticeships by introducing several reforms in the tertiary sector to amend the deficiency of education and training occurring. This has been achieved, to some extent, through a number of initiatives, for instance, the establishment of technical institutes through to institutes of technologies and polytechnics (ITPs) with the Education Amendment Act 1990 (Pollock, 2012).

The main reasons for undertaking this study were to explore the benefits and challenges between traditional apprenticeships to that of pre-apprenticeship training, and to determine the effectiveness of learning concerning both modes of training. Within the engineering industry there is renewed interest from employers to engage apprentices to improve the number of skilled tradespersons available.

In New Zealand, the two modes of delivery of trade training are defined as the 'traditional' apprenticeship mode and the pre-apprenticeship mode. The predominant method is the traditional apprenticeship contract of training - which is a contract between an individual, an employer and a training organisation. The apprenticeship training occurs mostly at the workplace where apprentices learn practical skills required in their specific industry. The secondary component of training occurs at an 
ITP where off-job training is conducted including practical and theoretical study facilitated by institute lecturers (refer to Figure 2.1 "works and learns at the workplace").

The second mode of training is through pre-apprenticeship training programs learning the knowledge and practical skills needed to gain successful employment in their relevant industry as apprentices. During the program, pre-apprentices are engaged in learning activities both at the institute and at the workplace (refer to Figure 2.2 "learns at an institute and completes assessment off-job").

The research investigates the experiences of pre-apprentice and apprentice pathways in skills and knowledge acquisition and assessment whilst learning on and off the job; that is, studying vocational education at institutes of technology and engaging in practical activities at the workplace. The engineering trades selected for this study were specifically in the automotive and refrigeration/air-conditioning/electrical disciplines, as they are typical of the engineering discipline trade groups studying at institutes of technology and workplace as apprentices. The work placements of the pre-apprentices were also included within the study.

Further reforms have included the introduction of the New Zealand Qualifications Authority (NZQA) in 1990, (Ministry of Education 2015). The NZQA has been responsible for overseeing the development and implementation of a national qualifications system for New Zealand (Green, Hipkins, Williams, \& Murdoch, 2003). Another significant change that occurred was the Industry Training Act 1992, which introduced competency based unit standard assessment. As a result, apprentices were able to be assessed to national standards at their workplaces, and to demonstrate evidence of knowledge and skills and prove their competency whilst working on the job.

Workplace learning has become a crucial focus of education, driven by changes to technologies, skill demands and increased work demands for employees in the workplace. This research focuses on apprenticeship and pre-apprentice modes of training with a view to gaining a better understanding of the pedagogy of trade based learning principles and the different contexts of learning through on-job and off-job learning. 
This study will provide additional research in pre-apprentice and apprentice training within a New Zealand context, as there is limited literature in this particular area of vocational education and training (VET). The findings of this study will endeavour to inform discussions for both pre-apprentice and apprentice modes of training for industry. It is critical that research is conducted to inform the literature on the aspects of how current training programmes are conducted including off-job and on-job training activities.

\subsection{Thesis Overview}

\subsubsection{The research questions}

The main research question for the study was:

What is the relative effectiveness of features of pre-apprenticeship and apprenticeship modes of delivery in engineering trades?

The four sub-questions were:

1. What are the benefits and challenges of different modes of training for engineering trade occupations in New Zealand?

2. How do different parties (employers, students, lecturers) view the different modes of training?

3. What learning and assessment practices contribute to high quality in the two modes of training?

4. What improvements could be made to quality?

\subsubsection{Research methods}

A qualitative approach was used for this inquiry. The data for this research was obtained through case studies (Yin, 1994). These case studies consisted of four cohorts of apprentices and pre-apprentices and their lecturers and employers. Semi-structured interviews, focus groups and questionnaires were utilised. The overall number of 70 participants in the study triangulated across the three cases was a suitable size to provide valid data for this study. 
The research focused on case studies based around four cohorts of students studying certificate programs at an Institute of Technology and Polytechnic (ITP) located in South Auckland in New Zealand. Two cohorts were studying full time as preapprentices: one cohort in refrigeration/air-conditioning/electrical engineering; and the other in automotive engineering. The other two cohorts included in the research were students working full time as apprentices and studying part time at the Institute in the same two trades. All of the programs included in the study were in engineering trades, and the students were all working towards their final National Certificate qualifications at level 3 on the New Zealand National Qualification Framework. The other participants in each case study included lecturers and employers who were associated with the student cohorts at the Institute and at the workplace.

It was expected that the findings of this study would inform discussions on the ways in which learning prior to and in the workplace might be more effectively facilitated and managed in the future. It was also expected that findings might arise concerning the effectiveness and quality of current training and assessment of engineering trade programs of study within New Zealand, and issues in apprenticeships and attrition within specific trades. There is currently little literature on the topic of preapprenticeship training programs in New Zealand and so the research was also expected to add to the knowledge base in this area.

\subsubsection{The structure of the thesis}

This thesis contains six chapters which present the findings, recommendations and conclusions of the research undertaken.

Chapter 1 provides an introduction and rationale of the research and sets the framework for the study that follows.

Chapter 2 presents the literature review on the topic and related literature on preapprenticeships and apprenticeships in VET for trade occupations. This study is situated in a New Zealand context and specifically explores trades in automotive and refrigeration/air-conditioning/electrical disciplines. This chapter includes an overview of literature of a comparable nature concerning VET from Australia, and other 
countries that reflect similarities to the New Zealand education trade training models identified in the study.

Chapter 3 discusses the research methodology and design, and the selection of research participants and sites (this data is presented in tables). The chapter also dicusses the methods used to collect the data, and the processes undertaken to analayse and interpret the data.

Chapter 4 presents the findings that emerged from the data through the experiences, perceptions and opinions of all the participants.

Chapter 5 elaborates on the research findings presented in Chapter 4. It is organised to consider and address the main research question, and to critically analyse the data pertaining to the four sub-questions.

Chapter 6 builds on the research findings presented and discussed in Chapter 5, and critically analyses issues that emerged as significantly affecting current training and assessment in engineering trade training within New Zealand. The chapter concludes with a discussion of the significance of the key research findings and considerations for future training, policy and further research. 


\section{Chapter 2: Background and Literature Review}

\subsection{Introduction}

This chapter provides background information and a review of related literature on pre-apprenticeships and apprenticeships within vocational education and training (VET) for trade occupations. The engineering trades covered in this study were specifically in automotive and refrigeration/air-conditioning/electrical disciplines. The study is situated in a New Zealand context, and the chapter also includes literature from Australia and other countries that reflect similarities to the New Zealand education trade training models identified.

New Zealand has faced dramatic changes in tertiary education over the past 20 years, particularly in the VET sector. These changes have proved to be beneficial and have substantially increased participation in education and training. There is now a far wider range of courses to cater for the needs of trainees and learners in the vocational sector as the New Zealand population grows, along with the engineering trade opportunities that are currently available in the workplace (LaRocque, 2007). The current population of New Zealand has reached 4,777,033 (Statistics New Zealand, 19 March 2017). The total number of employed apprentices in the country is estimated to be 43,000, with approximately 22,000 employed in the engineering industries (Industry Training Federation of New Zealand, 2017).

There have been many changes to VET in New Zealand and these have certain similarities across tertiary and vocational education in other countries.

The intention of the reforms was, and remains, to create and maintain a government-supported learning environment that facilitates learners moving through a wide range of learning opportunities. Policies provided for recognition of learning across different parts of the system and aimed to reduce sharp distinctions between different types of and different providers of education and training. (Crawford, 2016, p. 7)

This literature review outlines the history of the VET sector in New Zealand. It provides a significant background to trade training and highlights key reforms, as well as considering how the sector has developed and evolved over several recent years (Pollock, 2012). As well as examining the significant developments that have 
occurred in New Zealand, clear comparisons to reforms in the Australian VET system are also acknowledged and explored.

This chapter also identifies the establishment of the New Zealand Qualification Framework (NZQF) (1989) and illustrates how, since 1990, the New Zealand Qualifications Authority (NZQA) has been responsible for overseeing the development and implementation of a national qualifications system for New Zealand. In terms of pre-apprentices, upon completion of one year in tertiary study, graduates achieve 120 credits, and for two years in tertiary study, they can achieve a total of 240 credits. Pre-apprentices currently achieve a local certificate qualification from their ITP upon graduation. However, the credits they have achieved count towards the full New Zealand National Certificate at level 4 in their specific trade. Apprentices also study to achieve credits towards the same New Zealand National Certificate at level 4. Once students enter an apprenticeship, their study is completed on a part-time basis through learning on and off the job. This section also outlines how the NZQA ensures that all qualifications delivered are reviewed occasionally to fit the needs of the wider sector (which includes tertiary education institutions and senior secondary schools).

An area of literature significant to this study is work based learning for the purpose of educational programs covering both pre-employment and apprentice activities, as both include learning in the workplace. Work experience is an important component of preapprentice programs, as students studying these programs are required to attend a place of work in the relevant discipline for work experience opportunities. Lecturers involved in the work placement of these students are also required to be active in industry engagement procedures and have an understanding of workplace learning processes (Chan, 2012).

In engineering trade disciplines, students studying in a pre-apprentice program are required to complete a significant number of credits towards their national qualification. This reduces the time they would need to complete if they had entered straight into an apprenticeship, rather than study as a pre-apprentice. This is possible because a pre-apprentice works towards the equivalent qualification that an apprentice does, and covers part of the same curriculum that leads to the national certificate in their trade. 


\subsection{Apprentices and Pre-apprentices in New Zealand}

Wareham (2012), reporting on a study of the effectiveness of the training undertaken by plumbing and gas-fitting pre-apprentices, notes that there is little New Zealand literature on pre-apprentices. From a vocational perspective, work readiness is a similar requirement for employers who employ students studying within a vocational framework. Wareham (2012) found through his study with pre-trade plumbers that: "pre-trade programs are valuable because they shape the students' expectations of the work that they will be required to do, and introduced trade tools and their uses" (p. 6).There are a number of terms commonly used in New Zealand that relate to students studying full time programs prior to entering a trade, which can be confusing. The terms used are: pre-apprentices, pre-trades, pre-employment and pre-vocational. In this study, the term pre-apprentice is used to refer to students studying full-time programs in preparation for the workplace.

In the New Zealand VET sector the funding models used can have a significant influence on the modes of training that learners can choose to become tradespersons. For learners that choose the pre-apprenticeship pathway, there are various funding arrangements pertaining to the cost of the study programmes. For instance for learners that are 19 years of age and under, are eligible for free fees through the New Zealand Governments 'Youth Guarantee' option. For learners that meet the criteria of a Māori or Pacific heritage are able to obtain a Māori and Pasifika Trades Training (MPTT) scholarship. The scholarship is an initiative to encourage young Māori and Pasifika people to gain trade qualifications (New Zealand Ministry of Education, 2015). For other learners who are not eligible for the scholarships, they are required to pay a proportion of fees towards their training with a contribution from the NZ Government. Whereas apprentices are promoted by the respective Industry Training Organisations as a 'learn while you earn' model. However through the apprenticeship training agreement, apprentices may be required to pay for off-job training costs dependent on their training agreement and on their employer (Maurice-Takerei, 2015).

Learning a trade through a pre-apprenticeship generally involves engaging students in learning activities through collaboration with a tertiary institution, industry partners and workplace learning. This engagement includes study at a tertiary institute, industry based work experience and work based learning programs that are integrated 
with the formal curriculum leading towards the national qualification in a specific trade. For pre-apprentices engaged in work experience, learning occurs from undertaking real work practices in either paid or unpaid positions (Maurice-Takerei, 2015). In other circumstances, pre-apprentices will be learning through activities away from the workplace, such as in a simulated workshop (located at an ITP). Through engaging in these practical activities, students learn industry based knowledge and skills, which are part of the learning curriculum that is crucial to successfully succeed when working as full-time practitioners in an industry job (New Zealand Ministry of Education, 2012).

Chan (2011) identifies reasons why apprentices and pre-apprentices choose specific trades and examines how they transition from other places into apprenticeships. For instance, Chan found that a number of first year apprentices had entered into specific trades through connections with family or friends. However, for another group of first year apprentices, there was no initial support or connections with industry when they started their apprenticeships and in a number of cases, they became disengaged and left their apprenticeships.

The predominant reason for selection of a particular trade by both pre-trade students and first-year apprentices was interest in the work tasks; in particular, if the work matched the individuals' perceived affinities. (Chan, 2011b, p. 26)

Figures 2.1 and 2.2 illustrate the pathways for the different modes of learning for preapprentices and apprentices in the New Zealand context.

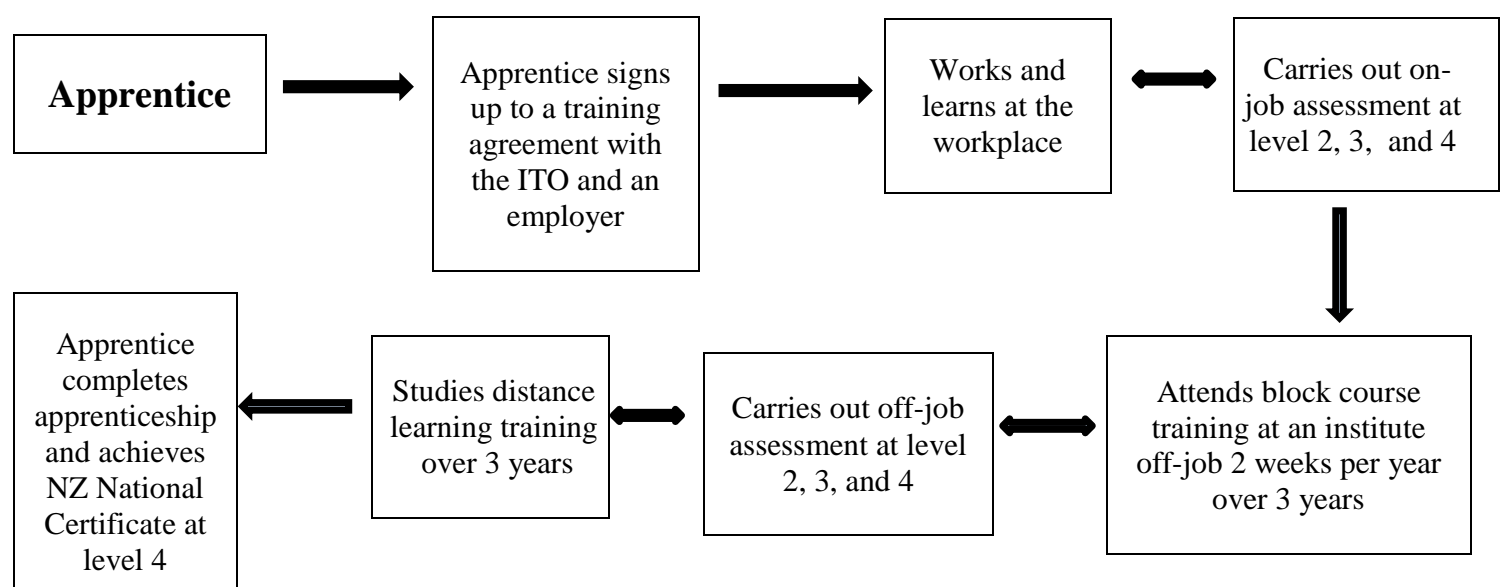

Figure 2.1. Apprentice mode of training 


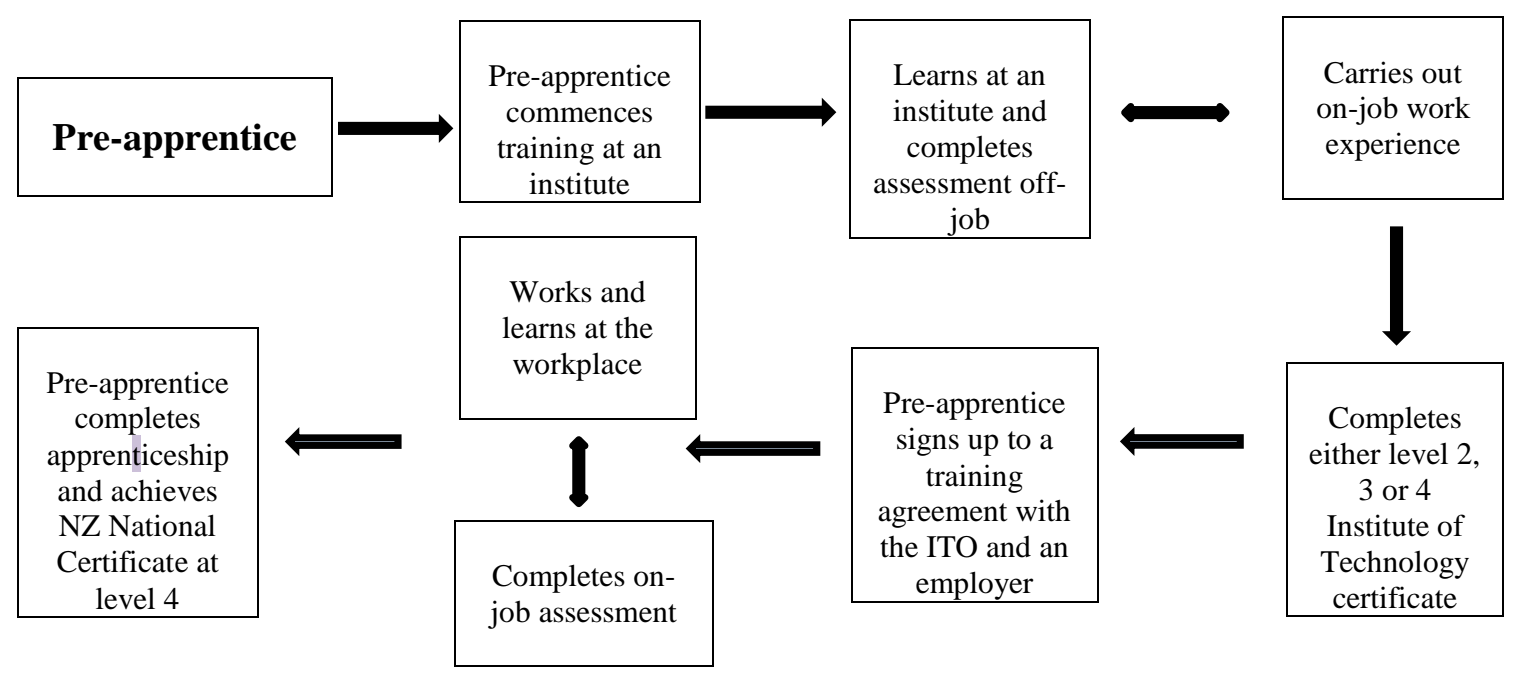

Figure 2.2. Pre-apprentice mode of training

\subsubsection{Training and assessment requirements for pre-apprentices}

For pre-apprentices studying a full time program, the training emphasis is on the skills needed to gain successful employment in their relevant industry. The usual number of credits a pre-apprentice achieves over one year of study is 120 . These credits count towards their final level 4 national certificate, which, depending on the trade, can total approximately 300 credits. The final credits and national qualification are usually achieved once students have graduated from their pre-apprentice programs and are engaged as apprentices at the workplace.

A pre-apprentice training program consists of knowledge based courses integrated with practical skills. The practical skills are taught in a workshop through small to medium sized projects covering tasks and practical topics that meet the current standards of the relevant industry. Most of the theory components are supported by some form of online learning platform that can be utilised during class time and also through a self-directed learning process. During the program, pre-apprentices are engaged in learning activities both at the institute and at the workplace (through work experience with specific companies). Students enrolled in these pre-apprentice programs are required to carry out all their assessment tasks at the institute (refer to Figure 2.2 "learns at an institute and completes assessment off-job"). Assessment consists of a combination of theory and practical subjects that meet the learning 
outcomes for the courses embedded in the program. For most courses, this consists of 15 credits that make up a total of 120 credits for the program.

Attached to the courses are unit standard assessments that are credited to the national certificate for the specific discipline on the completion of the program. Once the unit standards are achieved, they are listed on the NZQF. Unit standards express the main outcome that someone who is credited with that unit standard has demonstrated they know and/or can do. For instance, Unit Standard 920 has the title "Describe the construction and operation of manual and semi-automatic transmissions used on light vehicles" (NZQF, 2016).

All pre-apprentice programs are structured with an emphasis on the skills needed to gain successful employment in the relevant engineering industry. Students that complete a pre-apprentice program over one year achieve 120 credits towards a level 3 national certificate, and a further 120 credits at levels 3 and 4, providing the graduate from the pre-apprentice program with a total of 240 NZQA credits. Once a pre-apprentice has completed their pre-apprentice program either through one or two years at the institute they must sign an apprenticeship contract in the workplace to achieve the full requirement of credits in their trade qualification.

\subsubsection{Training and assessment requirements for apprentices}

In comparison, apprentices' training occurs mostly at the workplace where they learn the practical skills required in their specific industry (refer to Figure 2.1 "works and learns at the workplace”). Part of their training occurs at an ITP which can provide specific training their workplace may be unable to offer. This is called off-job training; usually this form of training includes practical block courses facilitated by institute lecturers to provide students with the skills necessary to meet their qualification. Apprentices may have previously completed a pre-apprentice program; however, that is not compulsory and apprentices can instead undertake their whole apprenticeship through on-job and off-job learning and assessment. Apprentices must achieve the required number of national certificate credits at level 3 and level 4 to complete their apprenticeship to become qualified. For instance, to achieve a level 3 National Certificate in Automotive Engineering, they have to complete a total of 268 credits. For a National Certificate in Automotive Engineering at level 4, they must 
complete a total of 132 credits. For apprentices in the refrigeration and air-

conditioning trade the requirement for a National Certificate in Refrigeration and Airconditioning at level 3 is 120 credits, and for the National Certificate in Refrigeration and Air-conditioning at level 4 the requirement is 284 credits (NZQF, 2016).

There is a recommended timeframe for completion although once the required credits are achieved then apprentices are able to obtain the national certificate qualification. For apprentices, the off-job training program may consist of knowledge based learning conducted through either distance learning and supported by some form of online learning platform, or night class attendance as with automotive trades. The off-job training, depending on the specific trade, may consist of two to three weeks of block courses, and one evening per week over a year for theory learning.

Figure 2.3 illustrates the interaction to workplace assessment for those involved in training pre-apprentices and apprentices through different organisations in a New Zealand context.

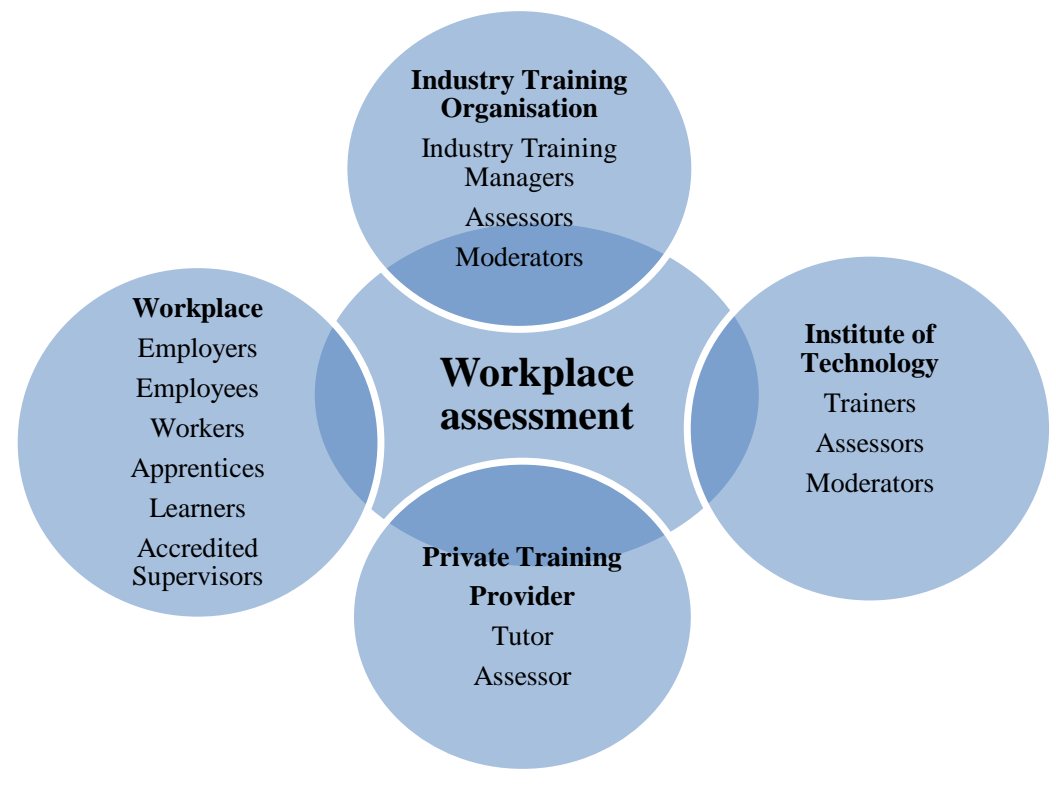

Figure 2.3. Workplace interaction to assessment through industry training managers, assessors, trainers, moderators, learners and apprentices 
Apprentices are assessed on-job by assessors who are usually from an Industry Training Organisation (ITO) or they can choose to use privately employed and trained assessors with the appropriate qualification. (The ITOs will be explained in more detail later in the chapter). The assessment consists of practical subjects that must meet the learning outcomes for the unit standard assessment embedded in their apprenticeship training agreement. Generally, $60 \%$ to $80 \%$ of an apprentice's qualification is achieved through completion of an on-job assessment manual supplied by the ITO which details the training plan and assessment through on-job learning and assessed by on-job assessors. The remaining $20 \%$ to $40 \%$ of the qualification is achieved through off-job learning as the apprentice completes specific theory/practical skills training for the workplace at an ITP.

\subsection{The History of Vocational Education and Training in New Zealand and a Comparison with Australia}

The history of VET (originally known as technical education) in New Zealand is a significant topic as it provides the New Zealand context for the study. The brief history provided here also shows that New Zealand qualifications have shaped the direction of the type of programs and courses delivered in New Zealand tertiary institutes, for instance, by the emergence of full-time pre-employment trade training. In addition, Industry Training Organisations (ITOs) were introduced to lead industry in the development of competency based qualifications, and training and assessments conducted at the workplace. This aspect of on-job and off-job training in VET is relevant to the study because the research focuses both on students studying as preapprentices at a tertiary institution, and also on those working in the workplace as apprentices while studying part time through block course training and evening classes and/or distance learning options.

New Zealand's origins of technical education are recorded as far back as the 1860s. Institutions were formed to provide technical training for workers who lacked any education and who entered the workforce directly from primary schools. The institutions that were set up in those early days became an integral part of the education system, and from the 1970s community colleges became widespread and 
provided continuing education according to the needs of the community (Dougherty, 1999).

\subsubsection{Technical institutes, polytechnics and institutes of technology}

The first technical studies offered in New Zealand were delivered through technical schools in the 1880s. These schools were operated by local education boards specifically to provide trades training. Workers who went straight to a trade after schooling paid fees to attend evening classes and traditionally went to these courses directly after finishing primary school (Pollock, 2012). Technical institutes were established in the 1980s, with their main focus on the vocational training that evolved out of technical sections in high schools. By 1986, the term polytechnic was adopted as the title for technical institutes, later being changed to Institute of Technology and Polytechnics (ITP).

As parts of reforms in the tertiary sector, a government paper published in 1990 recommended:

- that all tertiary institutions should become independent legal entities led by a chief executive and held accountable by individual charters;

- that competition between institutions should be encouraged; and

- that universities lose their monopoly over degrees. (Pollock, 2012, p. 4)

These recommendations were accepted and implemented from 1990, when the Education Amendment Act 1990 was passed. The Act defined tertiary education institutions as universities, polytechnics, colleges of education, specialist colleges and wānanga (Māori educational institutions) (Pollock, 2012).

Another form of teaching institution within New Zealand is the wānanga where the indigenous Maori people have the opportunity to learn through a predominantly Maori approach. The wānanga teach a wide range of programs including trade training in a number of pre-apprenticeships that prepare students for apprenticeships at the workplace. The whare wānanga (school of learning) (New Zealand Government, 2005-2016) were traditionally places of education for people of chiefly status (Pollock, 2012). In 1981, the first wānanga that was established was called Te Wānanga-o-Raukawa and was located in a town called Otaki in the Kapati Coast 
District in the North Island of New Zealand. However, until the Education Amendment Act 1990 was passed by the New Zealand Government, the wānanga could not be formally recognised as a tertiary institution. In 1993, two wānanga (Te Wānanga-o-Raukawa and Te Wānanga o Aotearoa) gained official status as tertiary institutions (Pollock, 2012). For this study on pre-apprentices and apprentices wānanga was not included.

As a result of the Education Amendment Act 1990, certificates and diploma qualifications have also been available through Private Training Establishments (PTEs). Prior to 1990, PTEs were well established but they grew in number as a result of the changes to education policy. Funding from the New Zealand Government became available in the year 2000 based on the number of equivalent full-time students (EFTSs) enrolled. In 2000, there were 54,741 enrolments in PTEs compared to 132,500 in institutes of technology and polytechnics (ITPs) and 29,912 at the wānanga. Enrolments in PTEs peaked at just over 83,000 in 2006. Enrolments dropped from this point but stabilised at around 75,000 for PTEs, while there were 186,400 enrolments in ITPs and 42,000 EFTSs in wānanga at the end of 2010. In 2011, the total number of PTEs grew to a record 716 (Pollock, 2012). According to current statistics, the number of registered PTEs has reduced to 550, with three wānanga and 18 ITPs (New Zealand Ministry of Education, 2016).

When students are employed at a workplace as an apprentice, the practical component of the curriculum is carried out there and practised until the student is deemed proficient. Once the student has reached this stage, a practical summative assessment can be completed and passed under the administration and scrutiny of the relevant ITO. Under recent approaches taken by the NZQA - through the introduction of learning outcomes and graduate profiles that will be the primary measure of the effectiveness of qualifications (NZQA, 2010) — apprentices will have more opportunities to acquire skills and develop capabilities in completing workplace tasks that require advanced skill levels (Chan, 2011b).

\subsubsection{Industry Training Organisations}

In New Zealand, Industry Training Organisations (ITOs) were established through the passage of the Industry Training Act 1992, and were given the task of producing and 
moderating qualifications made up of competency based unit standards that determine the assessment requirements. In 2002, the New Zealand Industry Training Amendment Act came into force to provide ITOs with a number of new roles relevant to economic growth. These included the development of strategic training plans to improve the functioning of labour markets, through the assessment of current and future skill needs of relevant industries (Vaughan \& Cameron, 2010).

Similarly, in Australia, Industry Skills Councils (ISCs) were set up in the early 2000s and funded by the Commonwealth Government to represent the amalgamation of 29 former national industry training advisory bodies. These ISCs provided input from industry to lead the development of competency standards and training packages endorsed by the National Training Framework committee (Misko, 2006). However, as in New Zealand, there have been ongoing reforms. Since July 2015, the ISC system in Australia has been replaced by the Australian Industry and Skills Committee (AISC), which was established to provide advice and leadership across the VET sector from an industry perspective, and which receives advice from Industry Reference Committees who are supported by independent Skills Service Organisations (SSOs) (Department of Education and Training, 2016).

One of the New Zealand ITOs' key functions is to arrange the delivery of training to apprentices and trainees within the workplace (as paid employees), which includes the assessment of training and the monitoring of training on and off the job. The off-job training requirements are contracted by ITOs to ITPs, in order for apprentices to carry out block course training and assessment in specialist areas required to meet their qualification requirements. Another important role of ITOs is as standard setting bodies that ensure the qualifications lodged onto the NZQF are updated and moderated to meet national standards. The ITOs have been established by particular industries and have a number of roles in the industry training system. They are currently responsible for the following: 
- Provide information about industry skill demand - to increase the real power of students, employers and industry, and to inform providers;

- Define national skill standards and qualifications required by industry—ensuring the value and relevance of investment in education and training; and

- Broker training to meet the needs of employees in industry-linking individual workplace learning to national industry skill needs. (Service IQ Industry Training Organisation, 2017, p. 1)

Initially, there were a total of 40 ITOs in 2011 and since that time the sector has undergone major change. Many ITOs have since either withdrawn from industry training or have merged to form new ITOs resulting in the current total of 11 ITOs (Tertiary Education Commission, 2015). The current ITOs that work with the engineering sector (which is within the scope of this study) are: Competenz (which covers mechanical and general engineering disciplines); the NZ Motor Industry Training Organisation (MITO); and the Skills Organisation (which covers electrical and plumbing disciplines). The current list of all ITOs and the changes that have occurred in the sector is available from the Directory of Registered ITOs (Tertiary Education Commission, 2015).

The New Zealand Government, via the Tertiary Education Commission (2015, p. 1), expects ITOs to:

- Enable working New Zealanders to complete nationally recognised qualifications;

- Create clear pathways towards advanced trade qualifications at levels four and above; and

- Build and maintain strong support from the industries they serve.

To give effect to these expectations, ITOs' statutory functions are to:

- Set skill standards for their industry; and

- Develop arrangements for the delivery of training.

The Industry Training Federation (ITF) is the national representative body for all ITOs in New Zealand, and it provides leadership and advocacy for apprenticeships and training in industry. The ITF is also research informed and undertakes a number of research projects to inform industry organisations and employer bodies of best practice to meet the requirements of the workforce (Industry Training Federation of New Zealand, 2014). 


\subsection{New Zealand Qualifications Framework}

\subsubsection{Industry Training Strategy and the New Zealand Qualifications Authority}

The Industry Training Strategy was introduced in the early 1990s as a response to a perceived lack of training by industry. As indicated by Green, Hipkins, Williams and Murdoch (2003), the trade training system in New Zealand was seen to have several weaknesses due to being centrally regulated, sluggish and unresponsive, and the number of apprentices had been declining. Another factor associated with the apprenticeship training system at the time was that it catered only to the trades sector as opposed to other apprenticeship training sectors. An objective of the Industry Training Strategy was to focus training on the qualifications framework under the New Zealand Qualifications Authority (NZQA). Since 1990, the NZQA has been responsible for overseeing the development and implementation of a national qualifications system for New Zealand. In 2001, the New Zealand Qualifications Framework (NZQF) was further developed to allow the registration of the New Zealand Certificate in Educational Achievement standards for school subjects.

All national qualifications are listed on the NZQF and national assessment standards are used for the purpose of assessing learners to a nationally recognised qualification to ensure that:

- clear outcomes are recognised;

- nationally consistent standards apply to the outcomes that are recognised; and

- existing knowledge and skills are recognised and credited on the Record of Achievement. (NZQA, 2016, p. 1)

Pre-apprentices and apprentices under the New Zealand qualifications system must comply with the assessment standards covered under the NZQF. National assessment standards consist of unit standard competency outcomes, and these unit standards are developed and moderated by ITOs. They are then listed on the NZQF to provide education and training providers with access to the relevant standards. The competency outcomes provide learners (including pre-apprentices and apprentices) with a clear indicator of the requirements of knowledge and skills described by 
outcome statements. Each outcome indicates a "level that is based on complexity, with level one the least complex and level ten the most complex" (NZQF, 2016, p. 14).

The common currency of credit values and levels enables the credits gained from standards to be portable amongst national qualifications and training of apprentices and learners. Gaining credits through assessment on the NZQF involves collecting evidence of learners' knowledge and skills, which are then judged against criteria, and expressed in learning outcome based methodology. To register assessment on the framework, evidence is collected from a variety of sources. The evidence that is required to meet the required learning outcomes will depend on the outcome statement of the unit standard, the situation of the assessor and the circumstances of the learner (NZQF, 2016). In New Zealand, when a pre-apprentice completes a program of study they receive a "local institute certificate" in the context of the trade and level studied. The credits achieved from that study are then accredited towards the appropriate national certificate once the pre-apprentice is contracted as an apprentice. Once an apprentice has completed the required number of unit standard credits, a full New Zealand National Certificate qualification is awarded, for instance, a National Certificate in Automotive Engineering (level 4).

A recent change to national qualifications in New Zealand was the introduction of the Targeted Review of Qualifications (TRoQ). This included the reviews of qualifications at levels 1-6 which were designed to:

\section{Reduce the duplication and proliferation of qualifications listed on the national framework. The reviews were initiated in response to concerns raised by employers, employees and unions about the clarity and relevance of qualifications, particularly vocational qualifications. (New Zealand Ministry of Education, 2012, p. 52)}

The review did not affect this study as the fieldwork took place in 2011.

In New Zealand, certain trades are legislated by government, and registration boards are responsible for monitoring and administering the registered persons. Registration for practitioners is a requirement for the refrigeration/air-conditioning and electrical trades but not for the automotive engineering trades that were part of this study. The minimum standards for registration, and the competencies required for each registration class, are set out and defined under the Electrical Wiring Registration 
Board (EWRB). For registered trades and professions, unit standards were previously required to be completed prior to gaining full registration to operate as a practitioner. To complete a national qualification, in most cases the unit standards were designed to be completed both on-job at the workplace, and in most occupations, there is also an off-job requirement. This was the case for both of the trades included in this study.

\subsection{Apprenticeship Training Overseas and in New Zealand}

\subsubsection{Apprenticeship training overseas}

In trade occupations, for instance in engineering, construction, electrical, hairdressing, culinary and other industries, apprenticeships have been a traditional way of learning while the learner is also employed, as a way of achieving skills relevant to the workplace. The term apprenticeship implies a contractual relationship between employer and employee. The fundamental feature of an apprenticeship which is undertaken through both employment and training directly benefits the apprentice and the employer. For an apprentice, the benefits include having a job while at the same time carrying out training for an occupation, and by learning skills passed on by qualified and skilled tradespersons. Employers have the benefit of training an apprentice in the way they want them to be trained in their specific industry. In Australia, another benefit for employers is that apprentices are paid at a reduced rate during their training period until their trade qualification is reached (Ray, 2001).

Apprenticeships have existed for a considerable period of time, and have their roots in Europe during the Middle Ages. They have been considered by many as an exemplar of high standards of workplace training (Lucas \& Spencer, 2015). However, as Snell (1996, as cited in Fuller \& Unwin, 1998) argues, until the establishment of state education in the 19th century, apprenticeships were more about the social control of youth than economic considerations. As indicated by Fuller and Unwin (1998), apprenticeships have survived the test of time and are still operational in different formats throughout many countries. It is acknowledged that apprenticeships are still a meaningful medium for the development and transference of occupational skills, knowledge and understanding (Bewick, 2014). 
Workplace learning under a supervisor allows full participation by apprentices in the processes of learning and working. Through observation and practice, apprentices can build technical skills, experience the sharing of tasks, and see how technical tasks relate specifically to theoretical knowledge and interpretation. Apprenticeship training has remained a functional and popular method of gaining a sound foundation of knowledge and skills, and Callan (2008) indicates that "the traditional model of apprenticeship training is still well regarded". He also states, however, "that it does need to evolve to remain useful and relevant" (p. 30).

Brown (2015) notes that much of the apprenticeships and trade training across Australia state, trade and institute specific. He maintains that the historical narrative of apprenticeships in the state of Victoria spanned four distinct periods. The first period was European settlement from 1851 to 1896 , where almost anyone working in industry was deemed to be an apprentice even though no formal training was present. This led to a narrowing of the skill sets and criticism of the standards of tradespeople. The second period was from 1896 through to 1927 which covered the Factories and Shops Act, where in 1905, apprentices working for the Victorian Railway were provided with day release classes for training. Brown describes the third period as being of "consolidated dual regulation over employment contracts and training agreements" (p. 35). This period also included the introduction of modular training in a number of trades, which led to competency based training. In the fourth and final period, Brown stated that vocational education became nationalised through the National Reform agenda and saw the introduction of Training Packages that are current to the present day. Brown concludes that:

one reason apprenticeship remains resilient is because learning through a combination of the experience of authentic work practice and training within a dedicated pedagogical space remains a very powerful way to learn - despite a problematic relationship, and way to earn. $(2015$, p. 37)

In describing apprenticeships, Fuller and Unwin (1998) state that they have three broad and inter-related dimensions: firstly, the contractual framework that the apprenticeship operates within and that covers the reciprocal rights and obligations between an employer and trainee; secondly, through the workplace environment that socialises apprentices; and thirdly, through informal and formal on-job and off-job learning experiences. They explore the concept of apprenticeships as a model for 
learning and argue that social and activity theories of learning can usefully underpin a re-conceptualisation of apprenticeships. They also indicate that a distinction between formal and informal education is unhelpful because it implies the superiority of learning which takes place within tertiary institutions over that which occurs in the workplace.

Ray (2001) describes how apprenticeships in Australia gradually improved during the 1970s, and the significant increases in apprenticeship numbers that took place during the 1990s, which were without historical precedent. These substantially increased numbers were due to the impact of globalisation and information technology. For Ray (2001), the main characteristic that had changed since 1990 was that the training role of apprenticeships had become more dominant than the employment role. Ray claims that this was due in part to the fact that the state and territory ministers in Australia took control of apprenticeships whereas previously this was not the case. He concludes that the traditional form of apprenticeships has had a long history in Australia, and their historical purpose of training artisans for traditional crafts and other contemporary trades has remained their main purpose up until the present day. Harris and Simons (2005) undertook a significant study looking at the retention of apprentices and trainees across a range of occupations and trades. A total of 437 participants were interviewed, drawn from four different groups, including apprentices/trainees who were employed, apprentices/trainees who had finished their training, and employers/workplace supervisors and teachers/trainers who were selected from a range of occupational areas. The intention of the study was to obtain multiple perspectives on retention, and to involve both current and recently completed learners. The findings identified factors related to the process of retention in the trades and how they combined to shape the process of retention. The study also searched for intervention factors that could be more amenable to enhance retention, and by doing so, was instrumental in highlighting key characteristics of retention, including: 
- issues concerning retention change over the period of a training contract;

- different actors hold different perspectives on retention;

- factors contributing to retention are inter-related and cumulative; and

- the process of retention is occupationally specific and that lack of retention is not necessarily the process of an unsatisfactory outcome. (Harris \& Simons, 2005, p. 6)

The factors identified under the category of context-oriented were identified as being most likely to affect retention, including interpersonal relationship with an employer, the kind of employer, the type of social networks at the workplace, and the nature and structure of the apprenticeship (Harris \& Simons, 2005). Harris and Simons sum up the issue of retention of apprenticeship/trainees as being a collective responsibility of all the stakeholders in VET. They claim that retention is:

One of the products to derive from a quality training system where an appropriate and realistic balance is achieved between the learning needs and aspirations of apprentices and the needs and expectations of employers and industry. (Harris \& Simons, 2005, p. 6)

For the purpose of this study, retention is seen as a significant factor in gaining useful data relating to students' success in terms of completion of their programs of study.

Germany is often held up as a leader in apprenticeships. In Germany, the main pathway for students wishing to enter a vocational trade is through the dual system training process. The dual system can be defined as an apprenticeship system where students sign up as an apprentice with an employer, and attend vocational training over perhaps one or two days per week with the rest of their time spent working at the workplace. As Greinert (1994, cited in Dessinger, Smith, \& Pickersgill, 2006) says, "The dualism of learning sites and legal responsibilities is considered to be the striking features of the 'German system' of vocational training”' (p. 36). The reliability of the dual system is with employers to be able to offer apprenticeships with relevant support from government. The other main contributor to the continued success of the dual system is that school leavers see apprenticeships as an option of equal status with other avenues of career opportunities (Dessinger, Smith, \& Pickersgill, 2006). 


\subsubsection{Apprenticeship training in New Zealand}

Even though apprenticeships in New Zealand have evolved since the Master and Apprentice Bill was introduced in 1865 (Murray, 2001), they are still seen as a relevant form of training for young people working towards a career in a trade occupation (Harbourne, 2014). Apprenticeships have evolved over the years from traditional crafts and artisan skills in the workplace, and the training that currently occurs involves carrying out learning through practice 'on-job' and learning 'off-job'.

The key components of an apprenticeship undertaken in New Zealand are:

- being employed in an industry;

- completing a relevant level 4 qualification of at least 120 credits; and

- meeting any regulatory requirements of the occupation. (Tertiary Education Commission, 2016, p. 1)

A significant change occurred in New Zealand through the Industry Training Act of 1992 with the introduction of unit standards assessment. Under this Act, apprentices had to be assessed at the workplace to national standards, and show evidence of knowledge and skills whilst on-job. Prior to 1993, there was no formal assessment at the workplace until the Industry Training and Apprenticeships Act 1992 Part 1 came into force.

As part of an apprentice agreement between the apprentice, employer and ITO, the ITO draws up a training plan in order to determine each party's requirements, which comprise the following:

- the qualification to be achieved;

- the required standards and/or competencies to achieve the qualification;

- other key skills the apprentice may require;

- the training process, delivery modes and assessment arrangements;

- the key milestones, achievement targets and goals; and

- a regular review and reporting framework. (Tertiary Education Commission, 2016, p. 2)

As Chan puts it (2013, p. 11): 
The main objective of apprenticeship is to ensure apprentices have access to adequate training and practice-based learning to become competent practitioners, entrusted with trade workers' or crafts persons' work tasks and responsibilities.

Chan (2011) also carried out an earlier report on the perspectives of first-year apprentices and pre-apprentices regarding completion of their studies. A range of factors were considered to explain reasons why apprentices and pre-apprentices made decisions to either continue or not continue with their careers in specific trades. Earlier studies (Industry Training Federation of New Zealand [ITF], 2007), had found that industry support at the workplace was a key requirement for apprentices to succeed and complete their apprenticeship. Chan (2011b) found a significant number of additional factors including workplace learning, and indicated an:

understanding of the need to put time and effort into learning, practicing and honing practical skills, the need to complete underpinning knowledge requirements, and the need to apply theory learnt through 'bookwork' to practice. (p. 36)

However, as also identified by Chan (2011), not all apprentices successfully completed their training as they believed their workplaces did not always meet expectations of what was necessary to be learnt at the workplace. Chan indicated that if the training provided was not what the apprentices perceived to meet their vocational goals, they were more likely to explore alternative career choices.

Vaughan, Gardiner, and Eyre (2012), in their research findings of on-job assessment in the construction industry in New Zealand, specify that a training plan is a critical tool to assist apprentices, employers and industry to work as a team to ensure that onjob assessment meets the requirements of apprentices and to ascertain competence. They state that:

The Training Plan is one of the key tools that help members of the assessment team to work together to a common purpose. The Training Plan contains overview details about the apprenticeship such as unit standards, credits and dates of assessment. It also contains more detailed records of workplace visits, discussions held, progress comments, evidence used to determine competence, and assessor judgements about competence. (Vaughan et al., 2012, p. 35)

Vaughan et al. (2012) indicate that a team approach and a shared responsibility around assessment techniques and processes proved to be more inclusive. They also found it 
was important for apprentices to be more active and responsive for their own learning and achievement.

\subsection{Pre-apprenticeship Training Overseas and in New Zealand}

In this section literature on pre-apprentices-firstly in New Zealand and then elsewhere-is presented.

\subsubsection{Pre-apprenticeship training in New Zealand}

Pre-apprentice programs in New Zealand are delivered over a period of one to two years. For school leavers, they provide a staging point from high school to a tertiary environment where they can study for a career in trade based industries. Not only are pre-apprentice programs popular with school leavers, but they also provide a choice for those who are looking to change their career path into an engineering trade based industry. The programs are specifically designed to bridge the gap between the various capabilities of school leavers and learners in all age groups. They also provide specialised industry skills and prepare students for employment in engineering trades workshops (Wareham, 2012).

In New Zealand trade industries, an increasing number of employees are involved in learning that occurs through structured training programs and learning that occurs authentically at the workplace. The New Zealand Ministry of Education 2014/2015 annual report (New Zealand Ministry of Education, 2016) indicates that there were over 565,000 students enrolled in formal tertiary education places, of which 96,600 were at certificate level 3 pre-vocational and 139,000 were engaged in industry based training, of which 41,800 were in apprenticeships. This number is steadily growing. For example, in $2012 / 13$, of 422,000 formal places, there were 48,400 at certificate level 3 pre-vocational and 138,000 were industry trainees, of which 34,762 were in apprenticeships.

Students enrolled in pre-employment programs gain relevant underpinning knowledge and practical skills prior to entering the workplace as an employee. Pre-apprentice experiences are seen by some employers as a preferred education option as students are more prepared and "work ready" by the time they enter into employment 
(Wareham, 2012). As Wareham explains, "They are usually more motivated to learn and committed to excel at the trades than those who have not done pre-trade courses" (2012, p. 6). This was recently acknowledged in a review of industry training conducted by the New Zealand Ministry of Education:

The completion of a pre-trade course is considered a bonus for seven employers and a prerequisite for two. Completing a pre-trade or industry-relevant qualification prior to beginning an apprenticeship or seeking employment was seen as valuable because, along with equipping applicants with practical skills, it showed the applicant had some knowledge of the industry and was committed. (2012, p. 52)

Learners who study on a full-time basis through pre-apprentice programs also spend a considerable amount of time at a workplace through undertaking either work placements or work experience activities. Figures released by the Tertiary Education Commission in 2013 indicate that:

Of those aged 15 years and over in the New Zealand population, 10.4 percent were engaged in formal provider-based education and 3.8 percent were engaged in industry training (see figure 4). Industry trainees accounted for 5.7 percent of the workforce. Overall, participation rates changed fractionally in 2013, with a 0.6 percent drop in the number of industry trainees in the workforce. (p. 2)

\subsubsection{Pre-apprenticeship training overseas}

In Australia, full-time study options are available similar to those in New Zealand. The inclusion of work placements are also utilised within courses, with the Australian system using Training Packages in which the qualifications require specific tasks to be achieved through assessment events. The units of competency mandate how the assessments must be carried out either off-the-job or on-the-job in the Australian context (Dessinger, Smith, \& Pickersgill, 2008).

Pre-apprentice programs, like other programs that integrate theory and practical skills, can show significant benefits in preparing workers for the workplace. In an Australian study by Dumbrell and Smith (2007), respondents reported that pre-apprenticeships were seen to increase the number of apprentice applicants to an industry, and also as an approach to preparing students for an apprenticeship by providing exposure to the workplace. In some industries, especially those employing electricians, it has become common practice for students to enter apprenticeships through pre-apprentice 
programs rather than entering directly into apprenticeships (Dumbrell, 2003). Preapprenticeship courses confer advantages for students and employers alike, due to apprentices being more prepared and work ready by the time they enter into employment (Callan, 2008).

When students have opted for a pre-apprentice program in New Zealand, they have the advantage of gaining their off-job training component towards their national qualification in a much faster time, usually reducing their apprenticeship by at least one year, compared to students who study part time as apprentices while in full-time employment. Pre-apprentice students have considerably more time available for fulltime study and are able to concentrate on their education, learning integrated knowledge and practical skills without the distraction of having to work concurrently (Wareham, 2012).As indicated earlier, students who choose the pre-apprentice option will gain credits towards a national qualification and achieve considerable work experience as a pre-apprentice at the workplace through practical learning opportunities (Wareham, 2012).

Dumbrell and Smith (2007) used surveys and case studies to determine whether preapprenticeship models of training were effective in addressing the number and suitability of potential apprentices in three key trades in Australia. The three trades identified, due to shortages of skilled workers, were in engineering, automotive and electrotechnology. The study provided evidence that pre-apprentice programs facilitate entry into related apprenticeships, and found that apprentices who had completed a pre-apprentice program were more likely to continue with further study in a related trade than others who had not completed a program. For electrotechnology, a pre-apprenticeship was more or less expected. The study also found that most preapprentice students surveyed intended to seek, or had already arranged entry into, the trade or industry related to their course (Dumbrell \& Smith, 2007). Two important purposes were identified by Dumbrell and Smith's study: firstly, a pre-apprenticeship is designed for industry related skills; and, secondly, to provide apprenticeships for those who cannot gain them under their own volition.

A comparative study by Dessinger et al. (2008) compared models of full-time and part-time vocational training, i.e., apprenticeships versus pre-apprenticeships in Germany and Australia, finding similarities but also significant differences between 
the countries. The vocational foundations that both countries were built on were traditional apprenticeship systems that relied on employment requirements in order for apprenticeship systems to be successful, as indicated under the dual system pathway model. As stated by the study's authors:

Both countries are facing some common problems with the traditional apprenticeship model (Model 2), which include the difficulty of attracting young people into some occupations and the reluctance of some employers to make the necessary investment in the system by employing young people in apprenticeships. (Dessinger et al., 2008, p. 45)

The study showed that both countries have gone some way to addressing the issue of skills shortages and the lack of apprentices by offering full-time vocational courses and introducing workplace experiences to authenticate the learning (Dessinger et al., 2008). The study also clearly showed that there were pre-apprenticeship type courses delivered in Germany.

Both workplace and college based learning programs are seen as being useful. Aarkrog (2005) contributes to the debate on learning and practice through the findings of a Danish study into vocational training programs for sales assistants. In a VET program, both theoretical training in a VET school and practical training at the workplace are necessary to develop competency. Aarkrog illustrates the importance of retaining the school and workplace parallel learning settings and was able to specify the components of the curriculum that are best learned in the VET school and in practice. His work also shows that specifically tailoring off-job and on-job training is conducive to improving trainees' achievements. In addition, careful matching of theory and practice is not only important to improve VET programs but also to improve lifelong learning as work related education.

\subsection{Work Based Learning}

The students who participated in the current research study were all engaged in some form of workplace learning. Students who study a full-time program based at a tertiary institution will be located at the workplace during their study program by being allocated to work placements to carry out an on-job work experience requirement. Students who attend courses on a part-time basis work in the workplace as employees, and as such complete considerable units of learning towards their qualification there. 
For the purpose of this study, work based learning is considered to be preapprenticeship work experience or apprenticeship training at the workplace. The work based learning component provides students with work experiences where they can learn and apply knowledge and technical skills in a particular trade. Therefore, in this instance, the learning may be occurring either by an apprentice as part of his or her job, or by a pre-apprentice for the purpose of gaining hands-on work experience at the workplace through an agreed work placement (Skill New Zealand, 2001).

Skill New Zealand (2001) states that work based learning relates to different jobs/tasks/activities undertaken at the workplace. It defines workplace learning as the formal acquisition of skills and knowledge at the workplace. Work based learning is understood by learning practical skills on-job and applying practice occurring on-job, with substantial elements of teaching and learning occurring off-job through learning with training providers at tertiary institutions. Work based learning has also been defined as:

Structured arrangements of learning which can be undertaken in the workplace and/or a simulated work environment using a range of learning methods and models. These may include on-the-job training, on-site training, work experience/placement, practicum, industry visits. (Booth \& Parkinson, 1996, p. 3)

Knight and Nestor (2001) define workplace learning as "learning or training undertaken in the workplace, usually on the job, including on-the-job training under normal operational conditions, and on-site training, which is conducted away from the work process (e.g. in a training room)" (p. 43). Similarly, their definition of work based training is "training provided by an organisation primarily for its own employees using the employer's own staff or consultants. Work based training can be conducted either onsite or at an off-site location" (p. 43). The definition given by the Australian National Training Authority (ANTA, 1997) for work based learning, however, is learning that pertains to "secondary and postsecondary students which provide opportunities to achieve employment related competencies in the workplace" (p. 43).

Training that has predominantly been delivered off-site at Technical and Further Education (TAFE) colleges, has been perceived by some as not reflecting the changes that occur at the workplace in terms of skill levels and currency of practice (Misko, 
2006). In the literature, several writers have challenged the effectiveness of off-job learning and consider that the learning that occurs away from the workplace may not be effective in terms of transferring the skills from the off-job training facility to the workplace. Lave and Wenger (1991) argue that for learning and practice to be effective and meaningful it must be in context. They stress that knowledge is said to be situated and must be used as a result of the activity, context and culture from where it was developed. This theory is one that supports the need for work based learning, as off-job learning may not provide the practice required to consolidate the skills learnt, therefore work based learning is seen as valuable (Cornford, 1996).

Smith and Harris (2000) provide a full review of the literature relating to the practice of work placements. Their work covers findings relate to three educational sectors (schools, universities and VET) for the purpose of determining policy and practice in the VET sector. It is common for educational providers to include in the curriculum a form of work placement where students actively participate in work based learning activities. Mitchell, Henry, and Young (2001) state that "work based learning is an effective approach for achieving the twin goals of workplace training capability and associated supportive culture within training provider organisations" (p. 2). Smith and Harris found that much of the literature and practice on work placements was based on assumptions, and there were two areas of contestation: "one being the nature of the workplace, the second is the nature of the learning" $(2000$, p. 5). Also noted in the review is that "while work placements clearly have benefits for students, it is less clear what exactly they are expected to learn from them" (p. 23).

In a United States context, Smith and Betts (2000, as cited in Brown, 2003, p. 2) state that:

The effectiveness of work-based learning is directly related to the quality and effectiveness of the partnership and its ability to deliver the following five key educational criteria:

Explicit learning outcomes; 
- Formal assessment processes;

- Identification and delivery of standards;

- Application of appropriate quality assurance and enhancement processes; and

- Recognition through the awarding of credit or certification.

For employers involved with on-job learning for students who are enrolled in institution based programs, Brown (2003) advocates that they be familiar with the above criteria, as work based learning requires them:

to devote time to the planning and review of on-the-job learning, assume clearly defined responsibilities related to their roles as trainers or supervisors, ensure that appropriate resources are available to support the program, and satisfy the needs of their learners while ensuring that they do not conflict with those of their employees. (p. 2)

The following points made by Taylor (2001, as cited in Brown 2003, p. 2) would assist employers with potential learners in the workplace:

- Provide input to educators on planning the learning program so that the resulting programs are in tune with business needs;

- Work with training providers to ensure that learners have prior knowledge of the job and are equipped with essential skills from the start;

- Outline the benefits that practicing supervision, guidance, and mentoring skills can afford employees who must use these skills with students in internships or apprenticeships; and

- Provide advice on health and safety and equity legislation that has implications for work-based learning.

Brown (2003) concludes that work based learning has certain advantages for those students who undertake this form of learning by helping them to "integrate knowledge and experience to gain a broad perspective of the learning and skill development that is required to make successful transitions from school to the workplace or further education" (p. 4). In addition, Brown states: "The highest quality work-based learning programs provide a variety of options, ranging from job shadowing to youth apprenticeships and they integrate these experiences carefully with traditional school based learning" (Bragg, 2000, cited in Brown, 2003, p. 4).

Billett (2001) states that workplace activities are structured by historical, cultural and situational factors which influence the type and quality of learning that occurs at work. There is a need, according to Billett, to consider development of workplace pedagogy 
for learning in the workplace. He indicates that, for many workers, in order for them to learn and to develop their vocational practice, the workplace is the only suitable place for that to occur.

Billett's (2001) work also focuses on the quality and type of learning that occurs within the workplace setting. He states that for good quality learning to occur, a key factor is the workplace's "readiness" to provide opportunities for learners to engage. He argues that how workplaces do this is critical for workplaces to become learning organisations, and describes this as a dynamic relationship between the learner and the workplace. He terms this "affordances" and advises that for any training or learning program to be a success, there must be good learning outcomes associated with "rich affordances" through opportunities to participate in work (Billett, 2001, p. 212).

A study by Harris, Simons, and Bone (2006) gives some insight into apprentices' learning and training preferences in the workplace, through reporting the perceptions of apprentices and their trainers. By examining the possibilities of mismatches between the apprentices and their trainers, the study determined some key points of difference between the apprentices and trainers in terms of learning.

- Learning preferences offer a useful starting point for considering how those engaged in supporting New Apprentices' learning in the workplace might approach their role. However, understanding how the nature of work shapes learning and training activity in any given context must be taken into account. The role of interpersonal relationships in the workplace-learning environment is also substantial and influential;

- Important features of New Apprentices' preferred learning environments are the quality of relationships with trainers and acknowledgement of their status as learners; and

- Attention needs to be paid to training and support which specifically addresses the capacity of trainers to manage the flow, structure and shape of work as a key part of their role in supporting learning of New Apprentices at work. (Harris, Simons, \& Bone, 2006, p. 9) 
During the time of the study by Harris et al. (2006), the term "New Apprentices" described apprentices and trainees in the workplace.

The Industry Training Federation of New Zealand (ITF) (2007) reports that experienced workers in the workplace play an important role in learning for apprentices; however, there may be a possibility for apprentices to avoid training if they are not involved and cannot see any significance for it. Where possible, if the experienced workers take on the role of on-job assessors, the learning for the trainees or apprentices may be enhanced.

Research by Chan (2011) on the perspectives of New Zealand apprentices and preapprenticeship students provides findings on the influences on young peoples' decisions to commence and continue with apprenticeships. These findings closely related to what was occurring at the workplace and three main factors were found.

1. The need to help individuals match their 'vocational imagination' with the workplace realities;

2. That support is required to help novices establish a sense of belonging to a workplace; and

3. Assistance is required to maintain engagement and momentum for apprentices' eventual completion of apprenticeship and qualifications. (Chan, 2011, p. 6)

Chan's study (2011) highlights important influences. For instance, apprentices in the workplace required support from others at their workplace to ensure they continued and completed their apprenticeship. Also required was "extrinsic motivational factors including the perceived reward at the end of apprenticeship" (Chan, 2011b, p. 38). The apprentices in the study reported that they were aware of the time and effort required to be put into learning, and to the importance of gaining practical skills to underpin their knowledge. Chan's study also made clear that for some apprentices, what they received in terms of workplace training did not meet the knowledge and skills required. It was a clear message that if authentic learning was to occur, the workplace had to meet the requirements pertaining to content and quality of what was delivered. If this was unavailable, a number of apprentices were able to find positions elsewhere and not continue on that pathway. For several, the alternative was to enter into pre-apprenticeship training to learn the skills for the same or a similar trade (Chan, 2011b). 
Billett (2001) concludes that further empirical studies are required to gain a better understanding of workplace learning practice in different and specific contexts and industry areas, that include some of the learning and benefits not yet known that may occur in everyday working conditions. He highlights the dangers of superficial learning and poor theoretical developments that are not just reserved for tertiary institutions but also apply to learning at the workplace. Billett suggests that workplace pedagogy is needed urgently in order to assist effective workplace learning.

When exploring workplace learning pedagogy, there are certain conditions that require consideration (Vaughan, 2008). These conditions include:

- the sociocognitive demands (task complexity, what skills the worker needs);

- the sociointeractional requirements (whether one needs to work in and interact with teams);

- the importance of the job within the organisation (impact that specific task has on larger work process, on organisation, and relative prestige of worker); and

- the access characteristics of knowledge (sometimes this is a technical questionwhere is the knowledge located and what do you need to read or understand?and sometimes this is a political question - who is and is not allowed access?). (Cullen et al., 2002, p. 34)

Vaughan (2008, p. 23) states that "while pedagogy (strategies for teaching and learning) is important, it is the culture of a workplace and the way that learning is organised and supported in a workplace that sets up what can be learnt and how it is learnt."

Fuller and Unwin (2011) describe expansive and restrictive models of apprenticeships in the United Kingdom (UK) as a measure of apprenticeship organisation. Expansive apprenticeships stretch apprentices so they can fully develop and demonstrate their potential. Restrictive approaches to apprenticeships limit the variable learning opportunities for apprentices. For pre-apprenticeship models of training in New Zealand, the measure of expansive apprenticeships would be appropriate because it integrates ITP based vocational education with workplace based skills development (as advocated by Fuller \& Unwin, 2011).

As indicated from this review on the topic of work based learning, there are many definitions given in the literature relating to learning within the workplace. However, there are some key characteristics of work based learning pertaining to the quality and 
effectiveness of learning that provide a relevant context for this study on preapprentices attaining work experience and apprenticeship training at the workplace. A significant aspect for both cohorts is the acquisition of knowledge, skills and competencies gained at a workplace that is prepared to participate in providing learning opportunities.

\subsection{Assessment Practices for Pre-apprentices and Apprentices}

\subsubsection{The New Zealand system}

To ensure that the learning process is complete, assessment has to be carried out in some way to judge whether learning has been consolidated and enable recognition to be given for learning. In practical based trades, assessment is conducted across the curriculum during the students' activity away from the workplace at an ITP or private training provider, and also at the workplace for on-job learning. Assessments are an essential aspect during practical activities, as quality of assessment is a significant factor in tertiary education. Due to the numerous demands of industry, and students engaged within the workplace that require assessment, there may be difficulties in achieving assessment from time to time. As indicated by Vaughan and Cameron (2009), assessment of learning in the workplace is characterised by a number of tensions: between validity and reliability; and between formative and summative forms of assessment.

\subsubsection{Authentic assessment}

Research by Hoy-Mack (2004) in New Zealand provides valuable information on technical prescriptions for evidence gathering, the validity of the evidence and assessment methods, and for assessor training. The study found that with ambulance workplace assessments, there was a clear validity and directness in the evidence gained for the assessments.

Vaughan (2008) in New Zealand undertook a review of literature on learning that is assessed in the workplace and the different approaches used with apprentices. The author discusses authenticity in assessment. Due to the nature of assessment in the workplace, Vaughan found that formative assessment was particularly relevant 
because it "informs learners of how they are progressing and redirects their future learning" (Tillema, Kessels, \& Meijers, cited in Vaughan \& Cameron, 2009, p. 22). However, as highlighted by the findings of the work by Tillema, Kessels, and Meijers (cited in Vaughan and Cameron, 2009, p. 22), the principles of authentic, valid and reliable assessment practices are not easily structured into the workplace as there is often a division between trainers and assessors.

In Europe, Stenstrom and Laine (2007) highlight the main differences between practice oriented models of assessment and traditional assessment in vocational education and training. As indicated in their report, one essential difference in assessment methodologies is how the assessment context is understood. For traditional methods of assessment, the actual assessment activity is arranged after the completion of a course as an event separate from the teaching process; while in practice oriented assessment, the assessment is part of the learning process.

\subsubsection{Workplace assessment}

Programs of learning in VET usually involve competency based learning styles, and assessment plays an important element in this process. Vaughan et al. (2012) found that apprentices in the building and construction industry had an improved and more effective system of assessment within the workplace due to an updated assessment process structure. Earlier research by Vaughan and Cameron (cited in Vaughan, Gardiner, \& Eyre, 2012, p. 7) resulted in the production of a Guide to Good Practice in Industry Training Organisation Structures and Systems for On-Job Assessment the Guide). The guide that was produced from research by Vaughan and Cameron (2009) was centred on four high-level principles for developing and maintaining good assessment structures:

- ITOs and workplaces should have a clear purpose for assessment and work together;

- The ITOs' assessment structures and systems must support the learning process;

- Good assessment systems require appropriately recruited, trained and professionally developed people; and

- Moderation contributes to reliability and validity. 
In some cases, according to Vaughan and Cameron (2009), there may be also a lack of educational expertise at the workplace due to weak assessor training. The tendency is for assessors who are generally workplace supervisors to focus on checking off competencies, as that appears to be the most efficient solution in the short term. Vaughan and Cameron (2009) suggest that in New Zealand, there needs to be more support for workplace assessors in their assessment role and that "there may well be structural-level possibilities that will support ITOs that can in turn support employers, their workplaces and their trainees" (p. 22).

Research conducted by Timma (2007) in Australia yielded some implications for workplace and assessment practices. These included ways that workplaces could move towards encouraging and supporting a form of learner accountability and selfdirection in terms of arranging components of their assessment. The study also found that the workers took on the responsibility for their own learning, and the on-job assessment was an extension of their regular work (Timma, 2007). Timma's research relates well to the research questions in this current study on learning and assessment outcomes for different modes of training, as it focuses on learning and assessment with workers at the workplace to gain an insight as to how assessment is approached and practised at the workplace.

\subsection{Summing up the Literature}

This review of the literature has indicated several favourable approaches of learning practices prior to and in the workplace for students in either pre-apprentice or apprentice programs of study. The literature has also indicated that there are some concerns with learning approaches in apprentice and pre-apprentice learning.

As indicated in the literature by Fuller and Unwin (2007), for apprenticeships to remain relevant there is a particular need for workers to adapt to changes occurring with technology in the workplace. For apprentices, the training courses that are available must also be relevant and apply to the learning and assessment that occurs either on the job or away from the workplace. This is a key point made by Callan (2008), who states that for the apprenticeship system to be useful and relevant it must be prepared to evolve to meet the requirements occurring in the workplace. The structure of trades training in New Zealand has significantly changed from the days 
when apprentices were not required to be assessed through any practical training at the workplace. Through the Industry Training Act 1992 and the introduction of unit standard assessment, apprentices are now required to show formal evidence of knowledge and skills whilst working on-job and proving competency (Industry Training Federation of New Zealand, 2009).

Favero (2003) makes the important point that training courses must reflect changes to the way that training and assessment is carried out. It is evident from the literature that the challenges that have been identified through changes to the apprenticeship model are indeed also valid today. This feature is also alluded to by Ray (1999), with earlier research that concluded that the training role of apprenticeships had become more dominant than the employment role.

An aspect of the literature pertaining to apprenticeship systems is the issue of retention of apprentices, as summarised by Harris and Simons (2005), and Chan, (2011a). All stakeholders involved in apprenticeships have a responsibility to ensure that quality training is continually maintained, otherwise there is the likelihood that apprentices will not be retained. Quality is a prominent issue throughout the literature and is identified as a critical issue not only for the teaching and learning that occurs in the workplace, but also for assessment methods throughout VET (Mitchell, Chappell, Bateman, \& Roy, 2006). The literature has clearly indicated that there is a lack of evidence to support the notion of quality training, and that there are several factors that could contribute to less than adequate training occurring in the VET sector. This study may be able to contribute further knowledge about what is meant by "quality" learning and assessment practices by apprentices and employers, and how it is achieved through courses of study in VET.

Pre-apprentice training may be seen as a good pathway for providing industry with well trained and skilled employees, rather than apprentices entering directly into the workplace without any prior preparation. The literature appears to support the view that pre-apprenticeship training is well placed in the current VET system. As indicated through New Zealand's Annual Tertiary Enrolment figures released by the Tertiary Education Commission (2013), pre-apprenticeship training has increased in popularity as an alternative training option to that of direct industry training programs. Through the results of this study, comparison of both methods of training will hopefully 
provide useful data as to the value of such training pertaining to pedagogy of learning and assessment in both training systems.

Dumbrell and Smith (2007) show that pre-apprenticeship training is instrumental in broadening the number of apprentices in the workplace, and ensuring that apprentices have gained relevant workplace exposure. A key consideration is how an apprentice gains exposure to the workplace; for instance, others have indicated that preapprentice programs may not necessarily be designed for industry related skills, but used as a skill formation system that builds on school based education in preparation for work (Winch \& Clarke, 2003). Aarkrog (2005), on the other hand, holds the view that both theoretical and practical workplace training are important factors to ensure that effective learning occurs.

A key message that can be drawn from the literature review is the importance of how learning occurs either at the workplace or away from the workplace. This study used an interpretive social science approach to interpret how the respondents gauged the effectiveness of their learning in both situations. Significant research has been carried out on work based learning, and healthy debate continues about good practice and effective models of learning for workers and trainees at the workplace. Mitchell et al. (2001) hold the view that workplace learning is an effective way of gaining workplace training capability alongside a supportive workplace culture. There are also clear distinctions between work placements to those of general workplace training (Smith \& Harris, 2000), and this is a key factor for VET practitioners to consider when considering work based training options and training methods for their students. Work placements and work based training factor as important considerations in the study of practice based learning.

Billett (2009) has identified several dimensions of workplace pedagogies, and paved the way for a better understanding of how to integrate what is learnt in a curriculum to that which occurs in the workplace. Fuller and Unwin (2002) have indicated that learners who are engaged in work placements need to understand the importance of workplace pedagogies, and how different skills are necessary when involved in workplace activities. Analysis from this research study may be useful to further inform pedagogical designs to improve curriculum learning and assessment at both ITPs and the workplace. 
As is shown from this literature review, fundamental historical and political influences have led to the current apprenticeship system in New Zealand trades training. The trades training programmes are an integral part of New Zealand's economy to ensure that trained and skilled tradesperson are available to sustain a skilled workforce to support the demands of a changing society. There have been many changes to New Zealand's technical education polices and the types of education institutes to support the training of apprentices and pre-apprentices which have formed the basis of this study. This research seeks to ascertain the benefits and challenges between traditional apprenticeships to that of pre-apprenticeship training. Significant gaps in the literature confirm that there is a lack of evidence to support the notion of quality training occurring in the New Zealand apprenticeship system. For work placements and work based training there is a need to strengthen the literature surrounding this aspect of training. In terms of assessment of learning in the workplace this is characterised by a number of tensions: between validity and reliability; and between formative and summative forms of assessment. These aspects are pertinent for this study of the relative effectiveness of features of pre-apprenticeship and apprenticeship modes of delivery in engineering trades. 


\section{Chapter 3: Research Methodology and Design}

\subsection{Research Questions}

The main research question for the study was:

What is the relative effectiveness of features of pre-apprenticeship and apprenticeship modes of delivery in engineering trades?

These were four sub-questions, which were:

1. What are the benefits and challenges of different modes of training for engineering trade occupations in New Zealand?

2. How do different parties (employers, students, lecturers) view the different modes of training?

3. What learning and assessment practices contribute to high quality in the two modes of training?

4. What improvements could be made to quality?

\subsection{Research Design}

The principal objective of this study was to examine the relative effectiveness of features of pre-apprenticeship and apprenticeship modes of delivery in engineering trades. The research approach adopted was qualitative. The project consisted of case studies of apprentices, pre-apprentices, lecturers and employers and involved semistructured interviews, focus groups and short questionnaires for the student participants. The study was carried out from 2012 to 2013 and focused on programs delivered at a New Zealand Institute of Technology (ITP), in the area of trades and technology and covering four specific courses in automotive and refrigeration, airconditioning, electrical and engineering. All student participants were involved in a stage of the apprenticeship "life-cycle"- the time from initial sign up leading to completion (Smith, Comyn, Brennan, Kemmis, \& Smith, 2009).

According to Neuman (2003), there are three major approaches to social science research that represent different ways of looking at the world that observe, measure and understand social reality. The three approaches are: positivism, interpretive and 
critical social science. For the qualitative research in this study, an interpretive social science research approach was used as the main methodology, to gain an in-depth empathetic understanding from the respondents' perspectives.

With regards to the research spectrum between positivism, interpretive social science and critical social science, the research that was conducted in this study aligned with the epistemological perspective of interpretive social science. The theoretical perspective was driven by the philosophical stance and the methodology chosen for the research, and according to Crotty (1998), to understand that the theoretical perspective is about knowing "how we know what we know" and that the "epistemology is about dealing with the nature of knowledge and its possible scope" $(1998$, p. 8).The positivist approach tends to use quantitative research techniques, and when conducting research the researcher remains detached, neutral and objective, and replicates the research of others; whereas interpretive social science research is more concerned with qualitative data collection (Neuman, 2003). The interpretive approach adopts an empirical orientation and is more concerned with how people interact and is defined as "the systematic analysis of social meaningful action through the direct detailed observation of people in natural settings in order to arrive at understandings and interpretations of how people create and maintain their social worlds" (Neuman, 2003, p. 76). The critical social science paradigm could be used to study apprenticeships; however it was not an approach that was suited for this study as the critical research paradigm stems from socio political traditions. As such critical inquiry focuses on the critique and transformation of current structures and relationships in historical, social, cultural and political contexts (Fossey, Harvey, McDermott, \& Davidson, 2002). This approach is not suited to the research questions of this study.

Case studies typically involve the observation of an individual unit; a group, community or even an entire culture; a particular organisation; or a selected activity (Bogdan \& Biklen, 1998). The rationale guiding the choice of research methods for this study was based on the research questions to help uncover the kind of understanding involved, and emphasis sought, in the initial preparation and development of essential knowledge and skills for work and in work. Using a research methodology with case studies as the preferred design enabled definite positive 
outcomes for this study through a concentrated qualitative approach. It is argued that a case study approach can be used either for qualitative or quantitative studies, or even used in a combination of both dependent on the type of samples being used (Yin, 1994). Merriam (1998) points out case studies seek "to understand specific issues and problems of practice" (p. 23). The case studies were of two cohorts of students who were studying full time on engineering pre-apprentice programs, and two cohorts of students who were working full time as apprentices and studying part time at the Manukau Institute of Technology.

When forming questions for a given piece of research, Yin (1994) advises that a determinant of whether the question is one that is suitable for a case study, is whether the research question is either of a descriptive or explanatory nature, and states that the type of questions suitable would be based on the "how" and "why" questions. Yin states "a research design is the logic that links the data to be collected and the conclusions to be drawn to the initial questions of a study" (1994, p. 18). The nature of the study and the questions that were asked met the characteristics of empirical qualitative enquiry that is part of case study research. As indicated by Yin (1984), the case study method involves using numerous sources and techniques when gathering evidence.

Case studies may use participant or non-participant observation techniques based on the nature of the research to be conducted. Participant case studies were not appropriate for this study on apprentices and pre-apprentices' learning, as in this mode the observer would take an active role in the group and there would be a potential for bias and the possibility of becoming too closely involved. Instead, a qualitative approach to the research design, using a combination of applied and exploratory techniques, was the preferred data collection method. To gain answers to the research questions being asked, preliminary demographic questionnaires, focus groups and semi-structured interviews were used. The questionnaires were used with the apprentices and pre-apprentices only to gain relevant background information on age, schooling, full-time or part-time work experience, and career pathways prior to the interviews being undertaken.

An aspect of case study design that requires due consideration when carrying out research, is whether the particular research to be undertaken would be relevant for 
either a single or multiple case study approach. Yin (1994) explains that single case studies are "those using holistic designs and those using embedded units of analysis", and "the major step in designing and conducting a single case design is defining the unit of analysis (or the case itself)" (p. 44). If a multiple case study design is used, Yin advises that the design should "follow a replication, not a sampling, logic and an investigator must choose each case carefully" (p. 51).

The case studies for this research study were based around four cohorts of students who were studying certificate programs towards a national qualification at an ITP in either an apprentice or pre-apprentice mode. Also included were lecturers and employers who were engaged in teaching and learning at the institute and at the workplace. Consideration for the development of a suitable protocol was part of the formal case study preparation as specified by Yin (1994). He lists the preparation as "the training for a specific case study, the development of a protocol for the investigation, and the conduct of a pilot case study" (p. 54). An emphasis on the protocol is deemed to be an effective method of "ensuring the reliability of the case study" (Yin, 1994, p. 54).

\subsection{Ethics Approvals and Issues}

Full ethics approval was granted by the Human Research Ethics committee (HREC) at the University of Ballarat (now Federation University Australia). Approval was also given from the ethics committee at Manukau Institute of Technology as the research was to be carried out at the Manukau site. (Refer to Appendix A for ethics approvals.)

The approval for ethics included the responsibility to meet eight ethical considerations from both institutions:

- Informed and voluntary consent;

- Respect for rights of privacy and confidentiality;

- Minimisation of risk;

- Limitation of deception;

- Social and cultural sensitivity;

- Research adequacy;

- Avoidance of conflict of interest; and 
- Respect for property rights.

As part of the ethics approval process, I attempted to identify all risks that might have arisen when conducting the research, and acknowledged my obligations and the rights of all participants. All requirements related to providing explanations to potential participants were clearly indicated through the process of obtaining their consent. All ethical and legal requirements were conveyed to the potential participants and they were provided with information through the plain language information statement (refer to Appendix B) about the purpose, methods, demands, risks, inconveniences, discomforts and possible outcomes of the research. The student participants engaged in the research study were reassured in writing that refusal to participate would not result in penalties or discrimination of any kind and would be totally voluntary. The participants were also informed that if they became unhappy or uncomfortable about continuing at any stage in the research they were able to withdraw from the study and cease any further involvement.

Ethics in qualitative research is very important, particularly if there are circumstances where the question of "power" between the researcher and participants may be seen as an issue (Creswell, 2007). My research involved dealing with students who were studying within the Faculty of Engineering at an Institute of Technology located in South Auckland. At the outset of the study and during the data collection phase, my role at the Institute was as a Head of School in the Faculty of Engineering. The Faculty at the time was made up of five Schools; I was Head of School for the School of Mechanical and Civil Engineering. In my position as Head of School there were no ethical risks in relation to any staff or students, and no unequal or power relationships between me as a Head of a School and the lecturers and students who were to be interviewed.

Towards the end of 2012 my position changed within the Faculty as the Institute experienced a restructuring process. All data had been collected and finalised at this point of time. Senior management positions were reorganised within the Faculty and as a result I took up a position as a Senior Lecturer. The student participants came from separate sectors within the Faculty that were the targeted areas for the research study. The programs within the sectors comprise a variety of delivery methods, 
including pre-employment courses, full-time professional courses, part-time industry apprenticeship block courses and distance learning courses.

All potential risks pertaining to the lecturers involved in the study were minimised, for instance: interview times were controlled to prevent fatigue; anonymity and confidentiality were protected at all times; and all collected data from interviews with staff were securely filed on the researcher's computer and were to be destroyed on completion of the research. All lecturers were reassured in writing that refusal to participate would not result in penalties or discrimination of any kind and was totally voluntary. All possible risks pertaining to the students through participating in this research were duly considered and it was acknowledged that all the risks could never be entirely eliminated. The employers were selected through their association with Manuaku Institute of Technology and their involvement in education and training in the disciplines engaged in the research. They were advised of the nature of the research; that their involvement was voluntary; that their identity would be kept confidential; and that they would not be advised of the names of the other participants at the Institute and at the workplace (Silverman, 2006).

\subsection{Research Participants and Sites}

The students who participated in the study were all enrolled in programs at Manukau Institute of Technology. Two case studies covered students who were studying full time on engineering pre-apprentice programs as part of which they were required to carry out on-job work experience. Work experience for the pre-apprentice programs requires students to engage in a form of work placement. The work experience was usually carried out over one day each week for the length of the program, consisting of a period of 500 hours or more. The objective for work experience was for students to gain an understanding of the nature of work occurring at a workplace, and to engage in hands-on activities in the area of work they were studying. The other two case studies were of cohorts of students who were working full time as apprentices and studying part time at the Institute. All of the programs were in engineering and the students were working towards their final national certificate qualifications at level 3 on the New Zealand National Qualifications Framework (NZQF). The case studies 
included research with the relevant employers and teachers of the students through semi-structured interviews.

\subsubsection{Pre-apprentices}

The pre-apprentices involved in this study were studying pre-employment programs they had chosen as an alternative pathway leading into a full apprenticeship in an engineering trade based industry. The style of teaching within the programs incorporated integrated knowledge and practical skills with a focus on "hands-on" practical workshop activities. Students in pre-apprentice programs were required to attend a workplace normally one day in a week to gain real experience within the trade related area pertaining to their particular discipline. Working in an industry setting within the engineering industry ensured the students gained additional handson experience at the workplace that prepared them for future employment in relevant trade related industries. When students attended pre-apprentice programs, the off-job component (at the ITP) counted as credit towards their final trade qualification. Students were also able to gain specific credits or practical unit assessments towards their national qualification achieved through on-job assessments.

The pre-apprentice programs were intended to prepare students for employment in automotive and engineering trade workshops, or to up-skill technicians already employed in the industry. The programs provided learning and assessment applicable for the engineering industry. Both refrigeration/air conditioning/electrical and engineering programs provided a pathway for students to progress into employment with additional knowledge and skills that would enable a shorter timeframe as an apprentice. Students who graduated from the pre-employment programs would receive substantial credits of learning (from 120 to 240 credits) and would be more likely to gain employment through the knowledge and skills gained from their course work and on-job work experience.

\subsubsection{Apprentices}

The apprentices involved in this study attended courses as part of their apprenticeship training arrangement. The training courses were delivered over a period of up to three 
years and provided students a way of completing their formal off-job and on-job training towards their final national certificates listed on the NZQF.

Students were required to attend off-job training at the Institute through studying at evening classes, distance learning or block courses where the education and assessment was carried out by their lecturers. Students were provided with tutorial classes on a weekly basis, and for the theory assessment, an examination centre was available on certain days throughout the academic year.

Apprentices learned a significant proportion of their practical skills on-job at a workplace where they were employed as an apprentice. However, as part of their training program, apprentices were also able to attend off-job practical as well as theoretical training at the tertiary institute. This training was arranged for the students to carry out practical skills which may not be usually available at the workplace. For some apprentices, their workplaces may have been unable to provide the relevant training for a particular task. For instance, some workshops might complete more general work or the tasks required might be too specialised for the workshop to undertake. Hence, in these cases, the tertiary institute provided the resources and relevant training tasks as an off-job option for the apprentices to learn and thus be able to complete the assessment package.

\subsection{Case Studies}

The research focused on case studies based around four cohorts of students studying certificate programs towards a national qualification at an ITP. Two cohorts were studying full time as pre-apprentices: one in refrigeration/air-conditioning/electrical engineering; and the other in automotive engineering. The two pre-apprentice cohorts were randomly selected from at least six other cohorts at the time of the study. The other two cohorts included in the research were apprentices studying part time at the ITP. The apprentice cohorts were selected because they were available for interview at the time of the study (they were attending training on a block course). Also included in each case study were lecturers and employers who were engaged in teaching and learning at the ITP and at the workplace, for each of the four cohorts.

A total of four case studies were thus involved in the research (refer to Table 3.1): 
- Case Study 1: Based around pre-apprentice students studying in refrigeration/air-conditioning/electrical at level 3 (two thirds into their program);

- Case Study 2: Based around pre-apprentice students studying in automotive at level 3 (two thirds into their program);

- Case Study 3: Based around Year 2 refrigeration/air-conditioning/electrical industry students at level 3 ( 2 week block course in the first term); and

- Case Study 4: Based around Year 2 automotive industry students at level 3 (1 week block course in the second term).

The four case studies totalled 70 participants, including the pre-apprentices and apprentices, lecturers and employers. The case studies each consisted of: a group of students, two employers involved with the students, and two lecturers who taught the students.

Table 3.1: List of case studies

\begin{tabular}{lccc}
\hline \multicolumn{1}{c}{ Case study name } & Number of students & $\begin{array}{c}\text { Number of } \\
\text { lecturers }\end{array}$ & $\begin{array}{c}\text { Number of } \\
\text { employers }\end{array}$ \\
\hline $\begin{array}{l}\text { 1. Pre-apprentices: } \\
\text { Refrigeration/air- } \\
\text { conditioning/electrical }\end{array}$ & $16(2 \times 5,1 \times 6)$ & 2 & 2 \\
\hline $\begin{array}{l}\text { 2. Pre-apprentices: } \\
\text { Automotive }\end{array}$ & $14(1 \times 8,1 \times 6)$ & 2 & 2 \\
\hline $\begin{array}{l}\text { 3. Apprentices: } \\
\text { Refrigeration/air- } \\
\text { conditioning/electrical }\end{array}$ & $13(1 \times 7,1 \times 6)$ & 2 & 2 \\
\hline 4. Apprentices: Automotive & $11(1 \times 5,1 \times 6)$ & 2 & 8 \\
\hline Total & 54 & 8 & \\
\hline
\end{tabular}

The following processes were employed for each participant group. The process used for the pre-apprentices and apprentices began with a preliminary questionnaire from the focus groups to gather background information prior to the interviews. Secondly, nine focus groups were held. The process used to gather opinions from the eight lecturers engaged in the study utilised semi-structured, face-to-face and in-depth interviews. These participants were the main lecturers engaged in teaching the courses 
associated with each cohort of students within their specific discipline. The process used to gather expert opinions from the eight employers from the refrigeration/airconditioning/electrical and automotive disciplines were also through semi-structured, face-to-face and in-depth interviews. The employers selected for the study had all been active in offering work experience to students; and five of the employers had employed previous graduate students.

The semi-structured focus groups that the students participated in included a preliminary questionnaire to gather background information. The questionnaire was closely aligned to the research questions, and an outline of the interview questions was given to the respondents in the consent forms (refer to Appendices $\mathrm{C}$ and $\mathrm{D}$ ). The questions used in the questionnaire are set out in Table 3.2 in Section 3.5.1 (refer also to Appendix E).

A total of 16 interviews were held with lecturing staff and employers. The interview questions related to the delivery of learning and assessment both at the workplace and away from the workplace. The questions used and how they related to the research sub-questions are set out in Table 3.3.

Questions used for both students and lecturers/employers included the following topics:

- methods and structures for learning;

- learning mechanisms;

- delivery of theory methods;

- interrelationship between practical and theory;

- learning in the workplace and away from the workplace;

- articulation between learning in and away from the workplace;

- roles of assessors, supervisors and tutors;

- work experience, preparation for on-job activity and availability of on-job tasks;

- $\quad$ support for practical, assessment processes, formative and summative activities; and

- length of period to achieve qualification. 


\subsubsection{Preliminary questionnaires}

The preliminary questionnaires given to the students prior to the focus groups were designed to gain a snapshot of their background, including information on age, schooling, full-time or part-time work experience, and career pathways. The questions were mainly of a factual nature, with the main information requested related to known facts that were relatively straightforward, such as age, sex, ethnicity, work history and previous qualifications. However, some information requested relied to a certain extent on opinions, such as views on further education or study, how current knowledge was gained, and how future plans fitted in with career aspirations. Denscombe (2010) indicates that:

Factual information does not require much in the way of judgement or personal attitudes on the part of respondents. It just requires respondents to reveal straightforward information (such as their address, age, sex, marital status or number of children). Opinions, attitudes, views, beliefs, preferences, etc. can also be investigated using questionnaires. In this case, though, respondents are required to reveal information about feelings, to express values and to weigh up alternatives in a way that calls for a judgement about things rather than the mere reporting of facts. (p. 157)

The questions within the questionnaires (see Table 3.2) were identical for all of the groups interviewed in the focus groups. As Denscombe (2010) states:

The important point here is that each person who answers the particular questionnaire reads an identical set of questions. This allows for consistency and precision in terms of the wording of the questions, and makes the processing of the answers easier. (p. 156)

This proved to be a useful exercise as relevant contextual data was available one to two weeks prior to the focus group meetings. Valuable insights were obtained into the respondents' backgrounds and ethnicity, along with an indication of how they learned and where that learning had taken place. Information concerning previous and current work experience and how that related to their aspirations regarding future career pathways was also captured. 
Table 3.2: Questionnaire questions for students administered prior to the focus groups

1. Please indicate your age group: (a) 16 to 20, (b) 21 to 25 or (c) 26 or over.

2. Are you (a) male or (b) female?

3. What ethnic background do you associate with?

4. What was your final year of study at school?

5. Please list all qualifications you have achieved at school and/or at a tertiary institution.

6. Are you currently working part time or full time?

7. Please state if you had any jobs before starting the course or currently working full or part time.

8. If currently working, does your employment relate to your current study?

9. Are you currently serving an apprenticeship?

10. If Yes, how long have you been in an apprenticeship? (Apprentices only) How many months/years have you been an apprentice?

11. Have you previously studied as a pre-apprentice? (Apprentices only)

12. What level of training are you currently at?

13. List the topics you have learned during your apprenticeship/pre-apprenticeship?

14. Did you learn more while you were (a) at work (on-job) or (b) at school/college/polytechnic (off-job)?

15. What is the time (in months/years) you expect it will take for you to complete your level 4 qualification?

16. (a) Describe your plan for further study and (b) How do you feel your apprenticeship/preapprenticeship will contribute to your plan?

\subsubsection{Focus groups}

All student interviews were conducted at the Manukau Institute engineering campus in small focus groups ranging from five to eight participants. This method was used for all the student focus groups at a time and venue that suited the participants. All the students who attended were quite willing to share their experiences and to provide additional contextual data.

The purpose of the focus group interviews were to allow those involved in the programs to describe in detail their perceptions and interpretations of their learning experiences. The key areas focused on were: teaching and learning styles and methods (at the workplace and at the Institute); the relationship between theory and practice; methods of assessment and relevance of on-job and off-job assessment; difficult or frustrating things that may have been experienced in the program/course; what could 
be improved in the program/course; and what benefits, if any, were received when attending the program/course. (The questions asked in the focus groups are listed in Table 3.3 and are also presented in Appendix F.)

Focus groups were instrumental in providing qualitative data to gain a picture of the participants' attitudes and opinions about their practices in learning activities.

Kitzinger (1994) and Wong (2008) state that the one feature that distinguishes focus groups from one-to-one interviews is the concentration on the interaction between research participants. Krueger (1994) indicates that focus groups provide qualitative data that "provides insights into the attitudes, perceptions, and opinions of participants" and that by using focus groups, it is possible to gain and capture "reallife data in a social environment" (pp. 9-18). The advantages of using focus groups include:

- Focus groups can be relatively low cost and provide quick results. The actual time and cost for planning, conducting, and analysing data may be relatively small when compared to alternatives such as survey projects and individual interviews;

- Focus groups are a flexible assessment tool. Interactions between the moderator and participants allow the moderator to probe issues in depth, address new issues as they arise, and to ask participants to elaborate on their responses;

- Participants may be more comfortable talking in a group than in an individual interview. Interactions can generate more discussion and, therefore, more information; and

- The data is in the respondents' words. It is easily understood and will provide insights into how respondents think about the topic. (Krueger, 1994, pp. 9-18)

Krueger (1994) also discusses possible disadvantages for using focus groups:

- The group setting can influence the responses of individuals, which is problematic when a dominant member affects the outcomes;

- The small numbers in focus groups can limit the extent to which the results can and should be generalized;

- The quality and quantity of focus group data is dependent on the ability of the moderator, making it essential that the moderator is carefully trained and skilful; and

- The qualitative nature of focus group data can make it more difficult to summarize and interpret than more quantitative types. (pp. 9-18) 
However, the advantages of using focus groups for this research more than outweighed the disadvantages as the groups were relatively easy to assemble, the participant numbers were significant, and the researcher gained valuable data from the respondents.

Denscombe (2010) suggests that focus groups are suitable for gathering information due to group dynamics that have three distinctive features:

- there is a focus to the session, with the group discussion being based on an item or experience about which all participants have similar knowledge;

- particular emphasis is placed on the interaction within the group as a means of eliciting information; and

- the moderator's role is to facilitate the group interaction rather than lead the discussion. (p. 25)

The questions that provided the framework for the focus group interviews were devised to align closely to the research sub-questions (see Table 3.3 and refer to Appendix F).

Table 3.3: Focus group interview questions

\section{All respondents}

1. What have been the most satisfying things about your apprenticeship/preapprenticeship training program?

2. What have been the most difficult or frustrating things about your apprenticeship/preapprenticeship training?

3. What skills do you need to be a good tradesperson? (relate to discipline)

4. Tell me about how your training in the workplace is carried out, and what you think about it?

5. Tell me about how you are assessed, and whether you think it is appropriate?

6. What do you expect will be the benefits of attending the program/course?

7. How can your program/course be improved?

8. What do you think that your strengths are in practical skills for current work requirements?

9. Are there any skills that the program has helped you develop for your future career?

10. What additional knowledge do you need to advance your career?

11. What further thoughts do you need to consider towards positive attitudes to work/study? 
Apprentices

12. How does the off-job training work?

13. Have you been satisfied with the training and support provided?

14. What are the key things that the trainer/boss needs to get right?

15. Do you think that being an apprentice is worthwhile?

16. Are there any suggestions about how an apprenticeship might be improved?

17. Are you able to complete all the on-job assessment requirements at the workplace? If not why not?

18. Do you get treated any differently to other workers because you are an apprentice?

19. Have you been satisfied with the training and support provided?

Pre-apprentices

20. Do you currently have a part-time job?

21. Is there any on-job training?

22. Have you been satisfied with the training and support provided?

23. Do you think that being a pre-apprentice is worthwhile?

24. What is the most important overall benefit you have gained?

25. Are there any suggestions about how a pre-apprenticeship might be improved?

26. Are you able to complete all the assessment requirements? If not why not?

27. Do you think that this program will help you make the transition to the workplace?

\subsubsection{Semi-structured interviews with lecturers and employers}

Face-to-face and in-depth interviews were conducted with eight lecturers engaged with learning facilitation within the courses. These lecturers were associated with each cohort of students within their own discipline; they were the main lecturers engaged in teaching the specific courses. The employers who were approached to engage in the research were from both the refrigeration/air-conditioning/electrical and automotive disciplines. They employed some of the students and provided work experience for students who were studying in the full-time programs. The eight employers were selected through their association with the ITP, their involvement in education and training, and their role in ensuring that workplace training was carried out correctly and according to the requirements of the curriculum. The employers were also actively involved in the assessment process as on-job assessors or managers of the supervisors engaged in training at the workplace.

All interviews were conducted through a semi-structured process, formulated from the associated research questions to obtain expert opinions from the lecturers and employers who contributed to the study. The interviewer decided not to use structured interviews, as according to Denscombe (2010), these would have been too restrictive 
and may have given limited responses to the questions. He says that structured interviews are:

interviews that involve tight control over the format of the questions and answers. In essence, the structured interview is like a questionnaire which is administered face-to-face with a respondent. The researcher has a predetermined list of questions, to which the respondent is invited to offer limited option responses. (Denscombe, 2010, p. 174)

Therefore, the reason for carrying out semi-structured interviews was to allow for the respondents to have some flexibility with regards to the questions and to be able to speak more freely on the matters raised during the interviews. Denscombe (2010) determined that semi-structured interviews (rather than a more structured interview methodology), can be of a more flexible nature to gather a wider response from interviewees.

With semi-structured interviews, the interviewer still has a clear list of issues to be addressed and questions to be answered. However, with the semi-structured interview the interviewer is prepared to be flexible in terms of the order in which the topics are considered, and, perhaps more significantly, to let the interviewees develop ideas and speak more widely on the issues raised by the researcher. The answers are open-ended, and there is more emphasis on the interviewee elaborating points of interest. (Denscombe, 2010, p. 175)

Denscombe (2010) also indicates that there are definite advantages to carrying out interviews over other methods, which are listed in Table 3.4. 
Table 3.4: Advantages of interviews over questionnaires, observations and experiments

\begin{tabular}{ll}
\hline \multicolumn{1}{c}{ Topics } & \multicolumn{1}{c}{ Advantages } \\
\hline $\begin{array}{l}\text { Depth of } \\
\text { information }\end{array}$ & $\begin{array}{l}\text { Interviews are particularly good at producing data which deal with topics in } \\
\text { depth and in detail. Subjects can be probed, issues pursued and lines of } \\
\text { investigation followed over a relatively lengthy period. }\end{array}$ \\
\hline Insights & $\begin{array}{l}\text { The researcher is likely to gain valuable insights based on the depth of the } \\
\text { information gathered and the wisdom of 'key informants'. }\end{array}$ \\
\hline Equipment & $\begin{array}{l}\text { Interviews require only simple equipment and build on conversation skills } \\
\text { which researchers already have. }\end{array}$ \\
\hline $\begin{array}{l}\text { Informants' } \\
\text { priorities }\end{array}$ & $\begin{array}{l}\text { Interviews are a good method for producing data based on informants' } \\
\text { priorities, opinions and ideas. Informants have the opportunity to expand } \\
\text { their ideas, explain their views and identify what they regard as the crucial } \\
\text { factors. }\end{array}$ \\
\hline Flexibility & $\begin{array}{l}\text { As a method for data collection, interviews are probably the most flexible. } \\
\text { Adjustments to the lines of enquiry can be made during the interview itself. }\end{array}$ \\
\hline $\begin{array}{l}\text { Interviewing allows for a developing line of enquiry. } \\
\text { High response }\end{array}$ & $\begin{array}{l}\text { Interviews are generally prearranged and scheduled for a convenient time } \\
\text { and location. This ensures a relatively high response rate. }\end{array}$ \\
\hline rate & $\begin{array}{l}\text { Direct contact at the point of the interview means that data can be checked } \\
\text { for accuracy and relevance as they are collected. }\end{array}$ \\
\hline Validity & $\begin{array}{l}\text { Interviews can be a rewarding experience for the informant. Compared with } \\
\text { questionnaires, observation and experiments, there is a more personal } \\
\text { talk about the method, and people tend to enjoy the rather rare chance to } \\
\text { note the ideas without being critical. }\end{array}$ \\
\hline
\end{tabular}

Source. Denscombe, 2010, p. 192.

Denscombe (2010) alludes to possible challenges that can occur throughout the interview process, for instance, the timeframe involved for data analysis is seen as a weakness with interviews. He states: "Analysis of data can be difficult and timeconsuming. Data preparation and analysis are 'end-loaded' compared with, for instance, questionnaires which are pre-coded and where data are ready for analysis once they have been collected" (p. 192). Also, the data obtained from semi-structured interviews is not "pre-coded and [has] a relatively open format" (p. 192). However, for the purpose of this research the issues outlined as disadvantages were not seen as obstructing the research process. The advantages (listed in Table 3.4) from using a 
semi-structured interview method proved to be productive in producing good qualitative data.

The lecturer information relating to their experience with both pre-apprentices and apprentices is detailed in Table 3.5 .

Table 3.5: Lecturer information

\begin{tabular}{|c|c|c|c|}
\hline Course name & $\begin{array}{l}\text { No. of } \\
\text { students }\end{array}$ & Lecturers & Experience \\
\hline $\begin{array}{l}\text { Case Study } 1 \\
\text { Pre-apprentice students: } \\
\text { Refrigeration/air- } \\
\text { conditioning/electrical }\end{array}$ & 16 & $\begin{array}{l}\text { Lecturer A } \\
\text { Lecturer B }\end{array}$ & $\begin{array}{l}\text { Both lecturers in this group have } \\
\text { had specific experience in this field } \\
\text { teaching both pre-apprentices and } \\
\text { apprentices }\end{array}$ \\
\hline \multirow[t]{2}{*}{$\begin{array}{l}\text { Case Study } 2 \\
\text { Pre-apprentice students: } \\
\text { Automotive }\end{array}$} & 14 & Lecturer C & $\begin{array}{l}\text { New lecturer with considerable } \\
\text { experience in the trade with } 2 \text { years } \\
\text { teaching pre-apprentices }\end{array}$ \\
\hline & & Lecturer D & $\begin{array}{l}\text { Long-term teaching experience in } \\
\text { automotive with up to } 20 \text { years } \\
\text { teaching both pre-apprentices and } \\
\text { apprentices }\end{array}$ \\
\hline $\begin{array}{l}\text { Case Study } 3 \\
\text { Apprentice students: } \\
\text { Refrigeration/air- } \\
\text { conditioning/electrical }\end{array}$ & 13 & $\begin{array}{l}\text { Lecturer E } \\
\text { Lecturer F }\end{array}$ & $\begin{array}{l}\text { Both lecturers in this group have } \\
\text { had specific experience in the } \\
\text { industry teaching both pre- } \\
\text { apprentices and apprentices }\end{array}$ \\
\hline $\begin{array}{l}\text { Case Study } 4 \\
\text { Apprentice students: } \\
\text { Automotive }\end{array}$ & 11 & $\begin{array}{l}\text { Lecturer } G \\
\text { Lecturer H }\end{array}$ & $\begin{array}{l}\text { Both lecturers in this group have } \\
\text { had specific experience in the } \\
\text { industry in teaching both pre- } \\
\text { apprentices and apprentices in } \\
\text { automotive trades }\end{array}$ \\
\hline Total & 54 & 8 & \\
\hline
\end{tabular}

The interviews for the lecturers and employers were undertaken after the student focus group interviews as this was seen as a more appropriate time in the data collection phase. As the lecturers (also referred to as staff) had already been approached for permission for their students to be interviewed, they already had an understanding of the nature of the research and were quite comfortable to respond to the questions and to undertake one-on-one interviews. All the interviews were planned to take up to one hour, but some went a little longer as the lecturers were keen to offer their opinions on 
the teaching and learning and other aspects of the courses they were involved with. All the interviews were digitally recorded and downloaded to the researcher's computer for transcribing. The interview transcriptions were checked for accuracy by the participants.

The summary of interview questions that were used with the lecturers is shown in Table 3.6.

Table 3.6: Summary of interview questions for lecturers

1. What is your role on the pre-apprenticeship program? Can you let me know how it is delivered

2. What have been the most satisfying things for you as a lecturer when delivering the preapprenticeship training program? (i.e., class and practical delivery, work delivery, curriculum)

3. What have been the most difficult or frustrating things about the pre-apprenticeship training program? (key points as q. 2)

4. How are the students assessed? Are you happy with how the students are assessed, and if not how do you think the assessment could be improved?

5. What do you expect will be the benefits for the students from attending the program?

6. What is the theory/practical ratio of the program? In your view is this appropriate or does it need adjusting?

7. Is there anything that you think could be improved with the program/course to benefit the students? (key points as q. 2)

8. For students to meet the graduate profile are there any skills that the course/program has not addressed?

9. Is there any on-job training provided at the workplace? If yes, how does that work? Do you feel that the students on the program are gaining enough training on the job whilst studying?

10. Do you think that pre-apprentice training is worthwhile? If yes, why? If no, why not? (relates to research q. 3)

11. Are there any suggestions about how a pre-apprenticeship might be improved?

12. Do you think that this program will help the students make the transition to the workplace?

13. What are your thoughts on a level 4 pre-apprenticeship program being developed at MIT?

The employers who were chosen to be interviewed were prepared to discuss their viewpoints pertaining to the pre-apprentices and apprentices in the study. All the employers were interviewed at their workplaces and were forthcoming with their responses in relationship to the research questions. The employers were pleased to be part of the study as they were all actively engaged in the training programs through either work experience and/or employment of a number of the pre-apprentices and apprentices. 
As with the other interviews conducted, all the interviews were digitally recorded and checked for accuracy.

Employers who were interviewed as part of the study are shown in table 3.7.

Table 3.7: Employer information

\begin{tabular}{|c|c|c|c|}
\hline Course name & $\begin{array}{l}\text { No. of } \\
\text { students }\end{array}$ & Employers & Company information \\
\hline \multirow[t]{2}{*}{$\begin{array}{l}\text { Case Study } 1 \\
\text { Pre-apprentice } \\
\text { students: } \\
\text { Refrigeration/air- } \\
\text { conditioning/electrical }\end{array}$} & 16 & $\begin{array}{l}\text { Sharpes Oxy-Air } \\
\text { (involved with pre- } \\
\text { apprentices and } \\
\text { apprentices) }\end{array}$ & \multirow[t]{2}{*}{$\begin{array}{l}\text { Small to medium size } \\
\text { businesses in air- } \\
\text { conditioning services }\end{array}$} \\
\hline & & $\begin{array}{l}\text { Sheppard-Aircon NZ } \\
\text { (involved with pre- } \\
\text { apprentices) }\end{array}$ & \\
\hline \multirow{2}{*}{$\begin{array}{l}\text { Case Study } 2 \\
\text { Pre-apprentice } \\
\text { students: } \\
\text { Automotive }\end{array}$} & 14 & $\begin{array}{l}\text { Moyes Panmure (involved } \\
\text { with pre-apprentices and } \\
\text { apprentices) }\end{array}$ & \multirow{2}{*}{$\begin{array}{l}\text { Medium size franchise } \\
\text { businesses dealing in } \\
\text { automotive engineering and } \\
\text { service }\end{array}$} \\
\hline & & $\begin{array}{l}\text { Honda NZ Manukau } \\
\text { (involved with pre- } \\
\text { apprentices and } \\
\text { apprentices) }\end{array}$ & \\
\hline \multirow[t]{2}{*}{$\begin{array}{l}\text { Case Study } 3 \\
\text { Apprentices: } \\
\text { Refrigeration/air- } \\
\text { conditioning/electrical }\end{array}$} & 13 & $\begin{array}{l}\text { Air Conditioning Services } \\
\text { (involved with pre- } \\
\text { apprentices and } \\
\text { apprentices) }\end{array}$ & \multirow[t]{2}{*}{$\begin{array}{l}\text { Medium size businesses } \\
\text { dealing in air-conditioning } \\
\text { and electrical services }\end{array}$} \\
\hline & & $\begin{array}{l}\text { Aqua fire air-conditioning } \\
\text { (involved with } \\
\text { apprentices) }\end{array}$ & \\
\hline \multirow[t]{2}{*}{$\begin{array}{l}\text { Case Study } 4 \\
\text { Apprentices: } \\
\text { Automotive }\end{array}$} & 11 & $\begin{array}{l}\text { Miller Motors (involved } \\
\text { with pre-apprentices and } \\
\text { apprentices) }\end{array}$ & \multirow[t]{2}{*}{$\begin{array}{l}\text { Small businesses dealing in } \\
\text { automotive servicing }\end{array}$} \\
\hline & & $\begin{array}{l}\text { Auckland Motors } \\
\text { (involved with } \\
\text { apprentices) }\end{array}$ & \\
\hline Total & 54 & 8 & \\
\hline
\end{tabular}

The summary of interview questions that were used with the employers is shown in Table 3.8. 
Table 3.8: Summary of interview questions for employers

1. What is your role on the pre-apprenticeship/apprenticeship course/program? Can you let me know how it is delivered?

2. What have been the most satisfying things for you as an employer involved in preapprenticeship/apprenticeship training courses? (i.e., class and practical delivery, work delivery, curriculum)

3. What have been the most difficult or frustrating things about the preapprenticeship/apprenticeship training program? (key points as q. 2)

4. How are the students assessed at the workplace? Are you happy with how the students are assessed, and if not how do you think the assessment could be improved?

5. What do you expect will be the benefits for the students from attending the course/ program?

6. What is the theory/practical ratio of the course/program? In your view is this appropriate or does it need adjusting?

7. Is there anything that you think could be improved with the course/program to benefit the students? (key points as q. 2)

8. For students to meet the graduate profile are there any skills that the course/program has not addressed?

9. Is there any on-job training provided at the workplace? If yes, how does that work?

10. Do you feel that the students on the course/program are gaining enough training on the job whilst studying?

11. Do you think that pre-apprentice/apprentice training at MIT is worthwhile? If yes, why? If not, why not? (Relates to research q. 3)

12. Do you think that the pre/apprenticeship program will help the students make the transition to the workplace?

13. What are your thoughts on a level 4 pre-apprenticeship program being developed at MIT?

The questions that provided the framework for the focus group interviews were devised to align closely to the research sub-questions (see Table 3.9). As indicated by Yin (1994), ensuring that the interview questions clearly relate to the initial questions for the study means that "the data to be collected and conclusions to be drawn will provide a conceptual framework \& an action plan for getting from questions to sets of conclusions" (p. 2). 
Table 3.9 illustrates how the research sub-questions relate to the interview questions for all respondents.

Table 3.9: Mapping of the student focus groups, lecturer and employer interview questions to the research sub-questions

Research sub-questions

Examples of interview questions

1. What are the benefits and challenges of different modes of training for engineering trade occupations in New Zealand?

\section{Student interview questions}

What have been the most satisfying things about your apprenticeship/pre-apprenticeship training program? What skills do you need to be a good tradesperson? (relate to discipline)

What do you expect will be the benefits of attending the program/course?

Are there any suggestions about how an apprenticeship might be improved - in your company, in the industry, more generally?

Do you think that being an apprentice is worthwhile? If yes, why? If no, why not?

\section{Lecturer interview questions}

What have been the most satisfying things for you as a lecturer when delivering the level 3 apprenticeship training course? (i.e., class and practical delivery, work delivery, curriculum) What do you expect will be the benefits for the students from attending the course?

Is there anything that you think could be improved with the off-job training course to benefit the students? (i.e., class and practical delivery, work delivery, curriculum)

\section{Employer interview questions}

What have been the most satisfying things for you as an employer involved in pre-apprenticeship/apprenticeship training courses? (i.e., class and practical delivery, work delivery, curriculum)

Is there anything that you think could be improved with the course/program to benefit the students?

2. How do different parties (employers, students, and lecturers) view the different modes of training?

\section{Student interview questions}

What have been the most difficult or frustrating things about your apprenticeship/pre-apprenticeship training?

Are there any skills that the program has helped you develop for your future career? How can your program/course be improved?

How does the off-job training work? Does it relate to what you do in your job - is it relevant? What are the good and bad things about off-job training?

Is there any on-job training? If yes, how does that work? Are you given time at the workplace to study or learn from other staff? If no, how are you expected to learn about the job? 


\section{Lecturer interview questions}

What have been the most difficult or frustrating things about the apprenticeship training course? What is your role on the apprenticeship course/program? Can you let me know how it is delivered?

Is there any on-job training provided at the workplace? If yes, how does that work? Do you feel that the students on the course are gaining enough training on-job whilst studying?

\section{Employer interview questions}

What have been the most difficult or frustrating things about the pre-apprenticeship/apprenticeship training program? For students to meet the graduate profile are there any skills that the course/program has not addressed?

What is your role on the pre-apprenticeship/apprenticeship course/program? Can you let me know how it is delivered?

3. What learning and assessment practices contribute to high quality in the two modes of training?

\section{Student interview questions}

Tell me about how your training in the workplace is carried out, and what you think about it?

Tell me about how you are assessed, and whether you think it is appropriate?

Have you been satisfied with the training and support provided by your trainer at the Institute and by your boss during your apprenticeship at the workplace?

Are you able to complete all the assessment requirements? If not why not?

\section{Lecturer interview questions}

Do you think that the courses delivered by the ITP will help the students achieve their qualification? (these courses are contracted by the ITO to ITP and is it possible for students to achieve their qualification as a trainee and not as an apprentice through the ITO)

For students to meet the current industry requirements are there any skills that the course has not addressed?

\section{Employer interview questions}

How are the students assessed at the workplace? Are you happy with how the students are assessed, and if not how do you think the assessment could be improved? What is the theory/practical ratio of the course/program? In your view is this appropriate or does it need adjusting? Do you think that pre-apprentice training is worthwhile? If yes, why? If no, why not? (relates to research q. 3)

4. What improvements could be made to quality?

\section{Student interview questions}

What additional knowledge do you need to advance your career?

What do you think that your strengths are in practical skills for current work requirements? 
Are you able to complete all the on-job assessment requirements at the workplace? If not why not? Have you been satisfied with the training and support provided by your ITO Training Managers?

What are the key things that the trainer/boss needs to get right for quality apprenticeship training?

Do you think that this program will help you make the transition to the workplace?

\section{Lecturer interview questions}

Do you think that the courses delivered by the ITP will help the students achieve their qualification? (these courses are contracted by the ITO to ITP and is it possible for students to achieve their qualification as a trainee and not as an apprentice through the ITO)

For students to meet the current industry requirements are there any skills that the course has not addressed?

\section{Employer interview questions}

Is there any on-job training provided at the workplace? If yes, how does that work?

Do you feel that the students on the course/program are gaining enough training on the job whilst studying?

What are your thoughts on a level 4 pre-apprenticeship program being developed?

Do you think that the pre/apprenticeship program will help the students make the transition to the workplace?

\subsection{Data Analysis}

Yin (1994) advises that "the analysis of evidence is one of the least developed and most difficult aspects of doing case studies" (p.102) and suggests when doing case study research that it is most important to have a general strategy in place at the outset. Yin recommends a "theoretical proposition guiding the analysis that helps to focus attention on certain data \& to ignore other data"; and secondly "developing a case description: a descriptive framework for organizing the case study" (1994, p. 102).

The analysis of the data was scheduled to take place after writing up the transcriptions from the focus groups with the students and the semi-structured interviews with lecturers and employers. The questionnaires were also arranged into charts for each participant group to obtain contextual data. Information related to age, schooling, full 
time or previous and current work experience, and how these related to their aspirations regarding future career pathways, was also captured. Valuable insights into the respondents' backgrounds and previous study and work history were also captured from the questionnaires to provide an indication of how they learned and where that learning had taken place. These are presented in Tables 4.3 to 4.9 in the next chapter.

In the data analysis a systemic and thematic process was used to determine themes emerging from the data (Teddlie \& Tashakkori, 2009). The text was reviewed for recurring words and subjects (Patton, 2002). Patton states that:

The process of searching for patterns or themes may be distinguished, respectively, as pattern analysis or theme analysis. I'm asked frequently about the difference between a pattern and a theme. There's no difference between a pattern and a theme. There's no hard-and-fast distinction. The term pattern usually refers to a descriptive finding, for example, almost all participants reported feeling fear when they rappelled down a cliff, while a theme takes a more topical form: fear. (2002, p. 110)

After searching the data using inductive analysis (Patton, 2002), and discovering patterns and emerging themes, it was possible to produce categories and determine comparative key themes to arrange the data. This was done to compare and contrast the order of the emergent key themes in order to address the research questions (Teddlie \& Tashakkori, 2009) in relationship to teaching, assessment and workplace learning, and to summarise the data.

As Denscombe (2010) recommends, once all the interviews were completed, emerging themes were established from the collective interview data to ensure that relevant information and any issues were either "real" or "correct".

Where possible, avoid basing findings on one interview-look for themes emerging from a number of interviews. Where themes emerge across a number of interviews, the researcher does not have to rely on any one transcript as the sole source of what is 'real' or 'correct'. A recurrent theme in interviews indicates that the idea/issue is something which is shared among a wider group, and therefore the researcher can refer to it with rather more confidence than any idea/issue which stems from the words of one individual. (Denscombe, 2010, p. 189)

The analysis of themes was completed as follows. Tables were produced from the interview transcriptions relating to key questions from the interviews, and capturing and identifying other themes from the responses from the focus groups and interviews. An example of a theme table is shown in Table 3.10 below. 
Table 3.10: Example of a theme table

\begin{tabular}{lll}
\hline \multicolumn{1}{c}{ Theme } & \multicolumn{1}{c}{ Occurrence } & \multicolumn{1}{c}{ Quoted example of theme } \\
\hline Practical activities & Question 1: Satisfying things in training program \\
\hline Knowledge and & Frequent & $\begin{array}{l}\text { "Putting the learning into practice" } \\
\text { "Hands on practical" } \\
\text { "Projects-building/ practical" } \\
\text { "Practical, working on equipment R\&A units" } \\
\text { "Practical is good" } \\
\text { "Electrical practice workshop/ fabrication" }\end{array}$ \\
& $\begin{array}{l}\text { "Learnt lots of knowledge" } \\
\text { "Gained enormously more theory than practical" } \\
\text { "Understanding of knowledge } \\
\text { electrical, theory Auto CAD" } \\
\text { "Maths were [sic] good" } \\
\text { "Learning basics" }\end{array}$ \\
\hline Course delivery & Infrequent & $\begin{array}{l}\text { "Excellent course" } \\
\text { "Thoroughly enjoyed the course" } \\
\text { "Very good MIT resources, first class" } \\
\text { "CAD, workshop/ fabrication, maths were good" }\end{array}$ \\
\hline
\end{tabular}

The themes that emerged from the data are listed below.

Themes from the pre-apprentice case studies:

- Work experience and workplace learning: Challenging features and benefits of the training at the workplace.

- Customer service/people skills and communication: Interacting with customers and personnel at the workplace.

- Knowledge and skills: In preparation for the workplace and access to work prospects.

- Assessment: Theory, practical, integrated and validity and timing of assessment.

- Training support on-job: Challenging and satisfying training.

- Work ready and gaining a job: Prior employment to entering the program, skills, and capabilities needed for the workplace.

- Practical activities: Practical based projects and hands-on practical learning within workshop activities. 
Themes from the apprentice case studies:

- Types of training: On-job and off-job, high expectations.

- Training systems: Time for training, challenging, and insufficient funding.

- Practical activities: Learning key skills, diagnostic and technical, lack of practical training.

- Assessment: Validity and relevancy and timing of on-job assessment.

- Training on-job: Inadequate, lack of support from key agencies.

- Attitudes: Work ethics, unresponsive, language, character.

- Customer service/people skills and communication: Interacting with customers and personnel at the workplace.

Stake (2000) identified that if a research question was developed pertaining to suspected issues of importance for the researcher, then the emphasis on the main question was researcher or "Etic" focused. For this study, the initial question was developed to explore issues around pre-apprentices and apprentices in trade training, As data was collected through the process of questionnaires and interviewing during the four case studies, some "Emic" issues emerged from the data (Stake, 2000). The themes that were Etic focused included workplace learning, knowledge and skills, customer service, assessment and on-job training and attitudes. The themes that were Emic focused included work readiness, hybrid training systems and mature learners.

\subsection{Summary}

This chapter used a case study research approach to conduct the investigation of the relative effectiveness of features of pre-apprentice and apprentice modes of delivery in engineering trades. The semi-structured interview methodology proved to be productive in producing good qualitative data. The rationale guiding the choice of research methods for this qualitative study using case studies is robust and is presented enabling sound data to be determined from the findings. The following chapters present the data, and discuss and analyse the research findings presented. 


\section{Chapter 4: Findings from Students, Lecturers and Employers}

\subsection{Introduction}

This findings chapter presents the participants' experiences, perceptions and opinions that emerged from the data. Three methods were used to obtain the data from the preapprentices, apprentices, lecturers and employers: a questionnaire, focus groups and interviews. The information obtained from these data gathering methods was then analysed for underlying common themes. All the study participants were male; as indicated by Statistics New Zealand (2013), there is a significant under-representation of women in trade occupations. The total number of women recorded as being employed in trades in 2013 was 5\%. This was classified in the statistics as skill level 3 occupations (Statistics New Zealand, 2013).

Table 4.1indicates the number of pre-apprentice students in the focus groups, lecturers selected from the specific courses and employers selected as partners for on-job work options. 
Table 4.1: Case study list

\begin{tabular}{|c|c|c|c|c|}
\hline Course name & $\begin{array}{l}\text { No. of } \\
\text { students }\end{array}$ & $\begin{array}{l}\text { No. of students } \\
\text { in focus } \\
\text { groups }\end{array}$ & $\begin{array}{l}\text { MIT lecturers } \\
\text { (selected from } \\
\text { the specific } \\
\text { courses) }\end{array}$ & $\begin{array}{l}\text { Employers (selected } \\
\text { as partners for on-job } \\
\text { work options) }\end{array}$ \\
\hline $\begin{array}{l}\text { Case Study } 1 \\
\text { Pre-apprentice } \\
\text { students: } \\
\text { Refrigeration/air- } \\
\text { conditioning/electrical } \\
\text { Year } 1 \text { (6 months } \\
\text { completed) }\end{array}$ & 16 & $\begin{array}{l}1 \text { group of } 5 \\
1 \text { group of } 6\end{array}$ & 2 interviewed & $\begin{array}{l}2 \text { employers } \\
\text { interviewed from } \\
\text { local refrigeration } \\
\text { and air-conditioning } \\
\text { companies. Involved } \\
\text { with work } \\
\text { experience. }\end{array}$ \\
\hline $\begin{array}{l}\text { Case Study } 2 \\
\text { Pre-apprentice } \\
\text { students: } \\
\text { Automotive } \\
\text { Year } 1 \text { ( } 8 \text { months } \\
\text { completed) }\end{array}$ & 14 & $\begin{array}{l}1 \text { group of } 8 \\
1 \text { group of } 6\end{array}$ & 2 interviewed & $\begin{array}{l}2 \text { employers } \\
\text { interviewed from } \\
\text { dealerships in South } \\
\text { Auckland. Both } \\
\text { involved with work } \\
\text { experience. }\end{array}$ \\
\hline $\begin{array}{l}\text { Case Study } 3 \\
\text { Apprentices: } \\
\text { Refrigeration/air- } \\
\text { conditioning/electrical } \\
\text { Year } 2 \text { (level 3) }\end{array}$ & 13 & $\begin{array}{l}1 \text { group of } 7 \\
1 \text { group of } 6\end{array}$ & 2 interviewed & $\begin{array}{l}2 \text { employers } \\
\text { interviewed from } \\
\text { local refrigeration } \\
\text { and air-conditioning } \\
\text { companies. Currently } \\
\text { have employed } \\
\text { apprentices. }\end{array}$ \\
\hline $\begin{array}{l}\text { Case Study } 4 \\
\text { Apprentices: } \\
\text { Automotive } \\
\text { Year } 2 \text { (level 3) }\end{array}$ & 11 & $\begin{array}{l}1 \text { group of } 5 \\
1 \text { group of } 6\end{array}$ & 2 interviewed & $\begin{array}{l}2 \text { employers } \\
\text { interviewed from } \\
\text { small workshops in } \\
\text { South Auckland. Had } \\
\text { previously employed } \\
\text { apprentices. }\end{array}$ \\
\hline Total & 54 & & 8 & 8 \\
\hline
\end{tabular}

The interview questions (see Appendices F- I) focused on the following key areas:

- teaching and learning styles and methods - at the workplace and at the Institute;

- the relationship between theory and practice;

- methods of assessment and relevance of on-job and off-job assessment;

- difficult or frustrating things that may have been experienced in the course;

- what could be improved in the course; and

- what benefits were there for the students, if any, when attending the courses. 


\subsection{Research Questions}

This chapter discusses and analyses how the research addressed the main research question and associated sub-questions which were the focus of this study.

The main research question for the study was:

What is the relative effectiveness of features of pre-apprenticeship and apprenticeship modes of delivery in engineering trades?

The four sub-questions were:

1. What are the benefits and challenges of different modes of training for engineering trade occupations in New Zealand?

2. How do different parties (employers, students, lecturers) view the different modes of training?

3. What learning and assessment practices contribute to high quality in the two modes of training?

4. What improvements could be made to quality?

\subsection{Findings from the Student Questionnaires}

The questionnaire was designed to determine the demographics and evaluate the data from the students' surveyed to gain a full background and clear overview of the students within each of the case study groups being interviewed. The questionnaires were given to all the students prior to the focus groups being undertaken and then they were prepared for analysis once completed. The responses were arranged into charts for each case study group to gain contextual data and information related to age, schooling, full time or previous and current work experience ,and how that related to their aspirations regarding future career pathways. Valuable insights into the respondents' backgrounds and ethnicity were also captured, giving an indication of how they learned and where that learning had taken place. Of particular interest, was that the students came from very different backgrounds and were very multicultural. As the study was conducted in South Auckland, it was representative of the diverse ethnic groups currently living in that part of the city. 
The groups listed below (Case Study Groups 1-4) represent the cohorts of students involved in the study, and the data derived from the questionnaires is also summarised in the following tables (refer to Tables 4.2-4.9) for each of the groups.

- Case Study 1: Pre-apprentice students-Refrigeration/air-conditioning/electrical

- Case Study 2: Pre-apprentice students-Automotive

- Case Study 3: Apprentice students-Refrigeration/air-conditioning/electrical

- Case Study 4: Apprentice students-Automotive

\subsubsection{Case Study 1: Pre-apprentice students-Refrigeration/air- conditioning/electrical}

Case Study 1 was a cohort of 16 full-time students who were studying in the refrigeration/air-conditioning/electrical pre-apprentice program towards their New Zealand National Certificate at level 3. The program duration was three days per week over 34 weeks for one year at 120 credits. During that time students were engaged in learning activities both at the Institute and also at the workplace. The program was intended to provide students with a theoretical knowledge and sound base of practical work, alongside an in-depth understanding of refrigeration/air-conditioning/electrical based trades. All formal assessment requirements for these students were carried out off-job to cover theory and practical learning. The aim of the program was to develop students' core practical skills in refrigeration, air-conditioning engineering and electrical; for example, to maintain, service and commission refrigeration and air conditioning plant and equipment effectively and in a safe and professional manner. The program was designed to act as an easier pathway for students to gain an apprenticeship in the industry as opposed to entering straight into an apprenticeship.

Table 4.2 shows the background demographic data and statistics for the students in the refrigeration/air-conditioning/electrical pre-apprentice cohort. 
Table 4.2: Background demographic data for pre-apprentice students: Refrigeration/air-conditioning/electrical

Pre-apprentice students: Refrigeration/air-conditioning/electrical

- Number of students and year when left school: 2 in 1992, 1 in 1996, 2 in 2004, 2 in 2007, 2 in 2008, 4 in 2009, 3 in 2011

- Student age group: 6 aged $16-20,5$ aged $21-25,5$ aged 26 or over

- Ethnic background: Chinese x 2, New Zealander (European) x 3, Indian x 7, Fijian x 3, Samoan x 2, Tongan $\mathrm{x} 1$

- Qualifications achieved:

National Certificate in Educational Achievement x 4, School Certificate x 3, other certificate $\times 3$, and higher qualification $\times 2$, and other NZQA qualifications $\times 5$

\footnotetext{
* National Certificate in Educational Achievement (NCEA) is the main national qualification for secondary school students in New Zealand. There are three levels of NCEA certificate, depending on the difficulty of the standards achieved. In general, students work through levels 1 to 3 in years 11 to 13 at school (http://www.nzqa.govt.nz/qualificationsstandards/qualifications/ncea/understanding-ncea/how-ncea-works/).
}

Ten of the Case Study 1 students were aged 21 and over, with only six students being of school leaver age. This was significant, as it showed that this group of adult students were progressing towards a career path in the refrigeration/airconditioning/electrical engineering industry at a later stage of life. The group was multicultural, representing an ethnic mix of backgrounds (refer to Table 4.2). A range of qualifications were achieved prior to entry into the pre-apprentice program, ranging from school certificate levels at NCEA levels 1,2, and 3 through to other national qualifications listed on the New Zealand Qualifications Framework, including higher qualifications at diploma level and one at bachelor level. There were only six students directly entering this program from school, while 10 students were changing career paths after achieving significant qualifications in other fields to enter into a trade in engineering.

Table 4.3 shows the participants questionnaire summary for the pre-apprentice students in the refrigeration/air-conditioning/electrical cohort. 
Table 4.3: Participants' questionnaire summary for pre-apprentice students: Refrigeration/air-conditioning/electrical

\begin{tabular}{|c|c|c|c|}
\hline Question & Topic & Summary & Significance \\
\hline $6(a)$ & $\begin{array}{l}\text { Work } \\
\text { experience } \\
\text { (jobs) prior to } \\
\text { starting the } \\
\text { course }\end{array}$ & $\begin{array}{l}\text { Work experience previously gained } \\
\text { were grouped into three areas: } \\
\text { Electrical trade } \\
\text { Air-conditioning \& refrigeration, } \\
\text { electrical, computers repairs, } \\
\text { electronics } \\
\text { Other trade } \\
\text { Sewing machine services, automotive } \\
\text { engineering, computers repairs and } \\
\text { building, mechanical engineering, } \\
\text { engineering (making roll formers), } \\
\text { chef assistant, plumbing } \\
\text { Non trade } \\
\text { Supermarket, waiter, warehousing, } \\
\text { soldier, bouncer, factory worker, } \\
\text { retail manager, factory operator, NZ } \\
\text { Army Medical Corps, customer } \\
\text { service }\end{array}$ & $\begin{array}{l}\text { Prior to entry onto } \\
\text { program a large range } \\
\text { of other work had been } \\
\text { achieved that included } \\
\text { related trade and non- } \\
\text { trade experience }\end{array}$ \\
\hline $6(b)$ & $\begin{array}{l}\text { Working part } \\
\text { time or full } \\
\text { time }\end{array}$ & $\begin{array}{l}3 \text { students were not working } \\
8 \text { were working on a part-time basis } \\
2 \text { students were working full time } \\
\text { and attending the course concurrently }\end{array}$ & $\begin{array}{l}\text { Majority of students } \\
\text { were working }\end{array}$ \\
\hline 7 & $\begin{array}{l}\text { Jobs before } \\
\text { starting the } \\
\text { course or } \\
\text { currently } \\
\text { working full or } \\
\text { part time }\end{array}$ & $\begin{array}{l}5 \text { students indicated previously } \\
\text { worked part time } \\
3 \text { worked full time } \\
3 \text { said they hadn't worked previously } \\
10 \text { indicated worked before the } \\
\text { course and worked during the course }\end{array}$ & $\begin{array}{l}\text { Majority of students } \\
\text { had worked in some } \\
\text { capacity previously } \\
\text { before the course }\end{array}$ \\
\hline 8 & $\begin{array}{l}\text { Employment } \\
\text { relates to } \\
\text { current study }\end{array}$ & $\begin{array}{l}\text { Of the } 16 \text { students } 10 \text { said they were } \\
\text { working but the work had no relation } \\
\text { to the course } \\
3 \text { students said that their work was } \\
\text { related and } 3 \text { gave no response to the } \\
\text { question }\end{array}$ & $\begin{array}{l}\text { Majority of students } \\
\text { were working but not } \\
\text { in the related industry }\end{array}$ \\
\hline 9 & $\begin{array}{l}\text { Apprentice- } \\
\text { ship }\end{array}$ & $\begin{array}{l}12 \text { students were not in an } \\
\text { apprenticeship } \\
4 \text { students said that they were in an } \\
\text { apprenticeship }\end{array}$ & $\begin{array}{l}\text { Majority of students } \\
\text { were not engaged in an } \\
\text { apprenticeship, } \\
\text { however } 4 \text { had } \\
\text { indicated that they } \\
\text { were in an } \\
\text { apprenticeship whilst } \\
\text { also studying on a pre- } \\
\text { apprenticeship course }\end{array}$ \\
\hline
\end{tabular}




\begin{tabular}{|c|c|c|c|}
\hline Question & Topic & Summary & Significance \\
\hline 12 & $\begin{array}{l}\text { Current level } \\
\text { of training }\end{array}$ & $\begin{array}{l}\text { All students stated they were } \\
\text { studying at level } 3\end{array}$ & $\begin{array}{l}\text { All students realised } \\
\text { that they were } \\
\text { studying at level } 3\end{array}$ \\
\hline 13 & $\begin{array}{l}\text { Topics learned } \\
\text { during } \\
\text { apprenticeship/ } \\
\text { pre- } \\
\text { apprenticeship }\end{array}$ & $\begin{array}{l}\text { Topics were grouped into relevant } \\
\text { areas: } \\
\text { Refrigeration Electrical and air- } \\
\text { conditioning x } 5 \\
\text { Computer Aided Drafting (CAD) } \\
\text { Computers } \\
\text { Mathematics }\end{array}$ & $\begin{array}{l}3 \text { main areas were } \\
\text { identified as being } \\
\text { learnt on the course }\end{array}$ \\
\hline 14 & $\begin{array}{l}\text { Learning (a) at } \\
\text { work (on-job) } \\
\text { or (b) at } \\
\text { school/college/ } \\
\text { polytechnic } \\
\text { (off-job) }\end{array}$ & $\begin{array}{l}8 \text { students said they learnt more when } \\
\text { at work } \\
6 \text { students said they learnt more from } \\
\text { being at off-job training } \\
2 \text { students did not respond to the } \\
\text { question }\end{array}$ & $\begin{array}{l}\text { Relatively even mix of } \\
\text { where the most } \\
\text { learning took place } \\
\text { between the workplace } \\
\text { and off-job }\end{array}$ \\
\hline 15 & $\begin{array}{l}\text { Time to } \\
\text { complete level } \\
4 \text { qualification }\end{array}$ & $\begin{array}{l}9 \text { students thought it would take } \\
\text { between } 1 \text { to } 2 \text { years } \\
3 \text { students felt it would take } 3 \text { years } \\
\text { to complete } \\
4 \text { students had no idea how long to } \\
\text { complete level } 4\end{array}$ & $\begin{array}{l}\text { Majority indicated } \\
\text { between } 1 \text { to } 2 \text { years to } \\
\text { complete level } 4 \\
\text { qualification }\end{array}$ \\
\hline $16(a)$ & $\begin{array}{l}\text { Plan for } \\
\text { further study }\end{array}$ & $\begin{array}{l}\text { Study plans divided into } 3 \text { groups: } \\
\text { Apprenticeship and get a job x } 8 \\
\text { Professional engineer, civil, } \\
\text { electrical, quantity surveyor x } 3 \\
\text { Refrigeration and air conditioning } \\
\text { engineer x } 5\end{array}$ & $\begin{array}{l}\text { All responses here } \\
\text { indicated that further } \\
\text { study in some form } \\
\text { was recognised as the } \\
\text { path forward, which } \\
\text { was aimed at } \\
\text { apprenticeships, and } \\
\text { professional } \\
\text { engineering }\end{array}$ \\
\hline $16(b)$ & $\begin{array}{l}\text { Pre- } \\
\text { apprenticeship } \\
\text { training } \\
\text { contribution to } \\
\text { fit future plan }\end{array}$ & $\begin{array}{l}\text { Out of all the comments only } 2 \\
\text { indicated no comments related to } \\
\text { future plan } \\
\text { Most other comments indicated that } \\
\text { pre-apprentice training would be } \\
\text { beneficial and would provide positive } \\
\text { contribution to individual future } \\
\text { plans. Other comments gave a few } \\
\text { ideas on training with future } \\
\text { planning. }\end{array}$ & $\begin{array}{l}\text { Majority said that pre- } \\
\text { apprenticeship training } \\
\text { was beneficial to } \\
\text { future plans }\end{array}$ \\
\hline
\end{tabular}


Prior to entry into the pre-apprentice program, a significant range of other work had been undertaken by the participants, including related trade and non-trade experience (non-trade being work unrelated to trades). The types of work previously gained were grouped into three categories: electrical; automotive trade; and other trade and nontrade. The knowledge and skills gained from these jobs would be relevant to the skill set required in the refrigeration/air-conditioning/electrical trade. An interesting aspect of the responses pertaining to the type of current work most of the students were engaged in was that the work was not related to the courses they were studying, but rather was a means of earning some income whilst studying. For example, jobs listed included waiters, a store person, petrol station attendants, drivers and warehousing. However, four students stated that they had signed up as an apprentice but were also studying on the pre-apprentice program to gain knowledge and skills in the trade. Concurrently, they were working at the workplace for the days they were not required at the Institute for study time. The topics that were identified as relevant were grouped into three main areas: refrigeration, electrical and air-conditioning; computer aided drafting (CAD); and mathematics.

Concerning the question on where the most learning had taken place, the responses indicated that eight students out of 16 had found they had learnt more from the workplace than they had through off-job study. Six students said they had learnt more whilst away from the workplace. In terms of career pathways, all the students in this cohort had clear goals as to the type of work and the way forward after completion of the pre-apprentice program. Students intended either continuing with an apprenticeship at the workplace and securing a job, or continuing on to a professional engineering career studying electrical, civil or refrigeration and air-conditioning. Comments about future plans indicated that most of the student in this cohort felt that the pre-apprentice program was beneficial and would provide a positive contribution to their individual future plans.

\subsubsection{Case Study 2: Pre-apprentice students-Automotive}

Case Study 2 consisted of 14 students studying full time in an automotive engineering pre-apprentice level 3 program of 120 credits over one year's duration. This program utilised courses designed to be delivered in a practical workshop environment 
integrating theory topics. The aim of the program was to provide the students with the knowledge and skills in vehicle and electrical technology to meet the current standards of the automotive industry. The courses within the program covered diagnosis, and repair and service procedures for most of the major motor vehicle systems, including engine and cooling, fuel and emissions, chassis and drivelines, heating, venting and exhaust, and electrical.

On completion of the automotive program graduates were able to continue on to learn specific skills in a number of specialised trade areas, for instance: light automotive, automotive electrical, heavy automotive or motorsport. The design of the various courses within the program provided opportunities for students who decided to choose optional subjects for various career pathways for progression into the automotive trades. When employed as an apprentice automotive technician, further study was needed to complete the required number of credits to gain the National Certificate in Automotive Engineering at level 4.

Table 4.4 shows the background demographic data and statistics for the students in the automotive pre-apprentice cohort.

Table 4.4: Background demographic data for pre-apprentice students: Automotive

Pre-apprentice students: Automotive

- Number of students and year left school: 1 in 2003, 1 in 2007, 1 in 2008, 2 in 2009, and 5 in 2010.

- Student age group:

11 aged $16-20$, and 3 aged $21-25$

- Ethnic background:

New Zealander (European) x 2, Indian x 3, South Pacific x 4, Maori x 4, South African x 1

- Qualifications achieved:

National Certificate in Educational Achievement x 4, School Certificate x 2, and other certificate $\times 6$, and NZQA qualifications $\times 5$

Eleven of the 14 students studying in the automotive engineering pre-apprentice group (Case Study 2) were under the age of 21 compared to the previous group (Case Study 1) where the majority were over 21 years of age. In the automotive group only three of the students had indicated that they were over the age of 21 and younger than 25 years 
of age. The majority of students' ethnic backgrounds were an even mix of Indian, Asian, Pasifika and Maori, with a minority of students from a European background. Most qualifications gained by the students prior to entry into the program were school based covering NCEA levels 1,2, and 3, with a number of previous automotive lower level certificate qualifications and two other trade based certificates achieved.

Table 4.5 shows the participants questionnaire summary for the students in the automotive pre-apprentice cohort.

Table 4.5: Participants' questionnaire summary for pre-apprentice students: Automotive

\begin{tabular}{|c|c|c|c|}
\hline $\begin{array}{l}\text { Question } \\
\text { number }\end{array}$ & Topic & Summary & Significance \\
\hline $6(a)$ & $\begin{array}{l}\text { Work experience } \\
\text { (jobs) prior to starting } \\
\text { the course }\end{array}$ & $\begin{array}{l}\text { Work experience previously } \\
\text { gained were grouped into three } \\
\text { areas: } \\
\text { Automotive trade } \\
\text { Worked at automotive } \\
\text { workshops } \\
\text { Other trade } \\
\text { Construction work } \\
\text { Non trade } \\
\text { Chemist, courier, supermarket }\end{array}$ & $\begin{array}{l}\text { Most of the work } \\
\text { experience listed } \\
\text { was in the } \\
\text { automotive trade }\end{array}$ \\
\hline $6(b)$ & $\begin{array}{l}\text { Working part-time or } \\
\text { full-time? }\end{array}$ & $\begin{array}{l}10 \text { students were working on a } \\
\text { part time basis } \\
4 \text { students were not engaged in } \\
\text { work }\end{array}$ & $\begin{array}{l}\text { Almost all of the } \\
\text { students in this } \\
\text { group were working } \\
\text { part time }\end{array}$ \\
\hline 7 & $\begin{array}{l}\text { Jobs before starting } \\
\text { the course or currently } \\
\text { working full or part } \\
\text { time }\end{array}$ & $\begin{array}{l}5 \text { students indicated previously } \\
\text { worked part time } \\
3 \text { worked full time } \\
3 \text { said they hadn't worked } \\
\text { previously } \\
1 \text { indicated worked before the } \\
\text { course and worked during the } \\
\text { course }\end{array}$ & $\begin{array}{l}\text { Prior to the course } \\
\text { starting almost all } \\
\text { the students had } \\
\text { previously worked }\end{array}$ \\
\hline 8 & $\begin{array}{l}\text { Employment relates to } \\
\text { current study }\end{array}$ & $\begin{array}{l}\text { For } 8 \text { students they were working } \\
\text { in work related to automotive } \\
\text { and for } 6 \text { there was no } \\
\text { connection to automotive }\end{array}$ & $\begin{array}{l}\text { Slightly more } \\
\text { students indicated } \\
\text { that whilst working } \\
\text { that the work was } \\
\text { related to the } \\
\text { automotive industry }\end{array}$ \\
\hline
\end{tabular}




\begin{tabular}{|c|c|c|c|}
\hline $\begin{array}{l}\text { Question } \\
\text { number }\end{array}$ & Topic & Summary & Significance \\
\hline 9 & Apprenticeship & $\begin{array}{l}\text { All } 14 \text { students were not in an } \\
\text { apprenticeship }\end{array}$ & $\begin{array}{l}\text { No students were } \\
\text { apprentices in the } \\
\text { automotive pre- } \\
\text { apprentice group }\end{array}$ \\
\hline 12 & $\begin{array}{l}\text { Current level of } \\
\text { training }\end{array}$ & $\begin{array}{l}\text { A full range of automotive and } \\
\text { electrical work }\end{array}$ & $\begin{array}{l}\text { A comprehensive } \\
\text { list of topics had } \\
\text { clearly been learned } \\
\text { in this group }\end{array}$ \\
\hline 13 & $\begin{array}{l}\text { Topics learned during } \\
\text { apprenticeship/pre- } \\
\text { apprenticeship }\end{array}$ & $\begin{array}{l}\text { All } 14 \text { students stated they were } \\
\text { studying at level } 3\end{array}$ & $\begin{array}{l}\text { All students } \\
\text { indicated that they } \\
\text { were at level } 3\end{array}$ \\
\hline 14 & $\begin{array}{l}\text { Learning (a) at work } \\
\text { (on-job) or (b) at } \\
\text { school/college/poly- } \\
\text { technic (off-job) }\end{array}$ & $\begin{array}{l}\text { For } 12 \text { students they learned } \\
\text { more from being at the } \\
\text { polytechnic. Only } 2 \text { said that } \\
\text { they learned more at work. }\end{array}$ & $\begin{array}{l}\text { Off-job learning was } \\
\text { listed as the main } \\
\text { place that students } \\
\text { had learned for this } \\
\text { group }\end{array}$ \\
\hline 15 & $\begin{array}{l}\text { Time to complete } \\
\text { level } 4 \text { qualification }\end{array}$ & $\begin{array}{l}\text { Mixed responses here, for } 5 \\
\text { students it was going to take } \\
\text { between } 1-2 \text { years, for } 9 \text { students } \\
\text { it was going to take from } 2-5 \\
\text { years of study to complete the } \\
\text { qualification }\end{array}$ & $\begin{array}{l}\text { The expected time } \\
\text { to complete the } \\
\text { level } 4 \text { qualification } \\
\text { was from } 2+\text { years }\end{array}$ \\
\hline $16(a)$ & Plan for further study & $\begin{array}{l}3 \text { students did not indicate any } \\
\text { plans } \\
4 \text { students said they would get an } \\
\text { apprenticeship } \\
1 \text { would study at another institute } \\
\text { The rest said that they would } \\
\text { work in the automotive industry }\end{array}$ & $\begin{array}{l}\text { Majority of students } \\
\text { planned to go into } \\
\text { an apprenticeship in } \\
\text { the automotive } \\
\text { industry }\end{array}$ \\
\hline $16(b)$ & $\begin{array}{l}\text { Pre-apprenticeship } \\
\text { training contribution } \\
\text { to fit future plan }\end{array}$ & $\begin{array}{l}2 \text { students have yet to work out a } \\
\text { plan } \\
3 \text { feel that the course will help to } \\
\text { determine goals to achieve } \\
\text { Others gave positive ideas as to } \\
\text { how the course will assist to gain } \\
\text { advantage in their career }\end{array}$ & $\begin{array}{l}\text { Majority agreed that } \\
\text { pre-apprenticeship } \\
\text { training was } \\
\text { beneficial to future } \\
\text { plans }\end{array}$ \\
\hline
\end{tabular}

The majority of previous work completed by the automotive pre-apprentice students was in the automotive trade, with a significant number having studied automotive at the lower level 2 program. Almost all the students were engaged in part-time work whilst they were studying their full-time program. Eight students out of the total 
number worked in some form of employment related to the automotive trade; for the rest of the students there was no connection to the automotive industry. Jobs noted in this category included security work and takeaway food bars. In this group, no students worked as apprentices. However, most of the students planned to go into an apprenticeship in the automotive industry once they had completed the pre-apprentice program. Three students did not know what they were going to do and had not stated that they had any plans for their future career.

\subsubsection{Case Study 3: Apprentice students-Refrigeration/air- conditioning/electrical}

Case Study 3 consisted of 13 part-time apprentice students who were studying in the refrigeration/air-conditioning- apprentice program towards their New Zealand national certificate at level 3. Their apprentice study required them to carry out at least $60 \%$ of their qualification through an on-job training and assessment manual supplied by the Industry Training Organisation (ITO) and assessed by on-job assessors at the workplace. A total of $40 \%$ of their qualification is achieved through off-job learning to complete specific theory/practical skills training for the workplace at an ITP.

Table 4.6 shows the background demographic data and statistics for the students in the refrigeration/air-conditioning apprentice cohort.

Table 4.6: Background demographic data for apprentice students: Refrigeration/airconditioning/electrical

Apprentice students: Refrigeration/air-conditioning/electrical

- Number of students and year left school:

1 in 2002, 3 in 2003, 2 in 2008, 2 in 2010, 2 in 2011 and 3 in 2012

- Student age group:

4 aged $16-20,5$ aged $21-2$ and 4 aged 26 and over

- Ethnic background:

New Zealander (European) x 7, Fijian x 3, Australian x 2, Korean x 1

- Qualifications achieved:

National Certificate in Educational Achievement x 7, School Certificate x 1, and other certificate $\times 5$, and NZQA qualifications $\times 4$ 
Of the 13 apprentices, nine were over 21 years of age. The ethnic mix in this group included nine apprentices identifying as New Zealanders, three Fijian Indians and one apprentice identifying as Korean. From the 13 apprentices, only four had previously studied as pre-apprentices.

Table 4.7 shows the participants questionnaire summary for the students in the refrigeration/air-conditioning/electrical apprentice cohort.

Table 4.7: Participants' questionnaire summary for apprentice students: Refrigeration/air-conditioning/electrical

\begin{tabular}{|c|c|c|c|}
\hline $\begin{array}{l}\text { Question } \\
\text { number }\end{array}$ & Topics & Summary & Significance \\
\hline $6(\mathrm{a})$ & $\begin{array}{l}\text { Work experience } \\
\text { (jobs) prior to } \\
\text { starting the course }\end{array}$ & $\begin{array}{l}\text { Work experience } \\
\text { previously gained were } \\
\text { grouped into three areas: } \\
\text { Electrical trade } \\
\text { Other trade } \\
\text { Non trade }\end{array}$ & $\begin{array}{l}\text { Most of the work experience } \\
\text { listed was in the electrical } \\
\text { and refrigeration/air- } \\
\text { conditioning trade with a } \\
\text { number of other trades listed }\end{array}$ \\
\hline 6(b) & $\begin{array}{l}\text { Working part time or } \\
\text { full time }\end{array}$ & $\begin{array}{l}\text { All working full time with } \\
\text { no students indicating any } \\
\text { additional part-time work }\end{array}$ & $\begin{array}{l}\text { All of the students in this } \\
\text { group were working in a } \\
\text { full-time capacity }\end{array}$ \\
\hline 7 & $\begin{array}{l}\text { Jobs before starting } \\
\text { the course or } \\
\text { currently working } \\
\text { full or part time }\end{array}$ & $\begin{array}{l}8 \text { students indicated } \\
\text { previously worked full } \\
\text { time } \\
5 \text { worked part time }\end{array}$ & $\begin{array}{l}\text { All students in this group } \\
\text { worked with a majority as } \\
\text { full time }\end{array}$ \\
\hline 8 & $\begin{array}{l}\text { Employment relates } \\
\text { to current study }\end{array}$ & $\begin{array}{l}\text { All respondents worked at } \\
\text { a job related to their study }\end{array}$ & $\begin{array}{l}\text { All apprentices working in } \\
\text { the electrical trade }\end{array}$ \\
\hline 9 & Apprenticeship & $\begin{array}{l}\text { All respondents worked } \\
\text { as apprentices }\end{array}$ & As above \\
\hline 12 & $\begin{array}{l}\text { Current level of } \\
\text { training }\end{array}$ & $\begin{array}{l}\text { Out of } 13 \text { students } 9 \text { had } \\
\text { not studied as a pre- } \\
\text { apprentice leaving } 4 \text { that } \\
\text { had }\end{array}$ & $\begin{array}{l}\text { The significant factor here is } \\
\text { that only a few students had } \\
\text { completed a pre- } \\
\text { apprenticeship program }\end{array}$ \\
\hline 13 & $\begin{array}{l}\text { Topics learned } \\
\text { during } \\
\text { apprenticeship/pre- } \\
\text { apprenticeship }\end{array}$ & $\begin{array}{l}\text { All } 13 \text { students were in an } \\
\text { apprenticeship ranging } \\
\text { from } 8 \text { months to } 2.5 \\
\text { years }\end{array}$ & $\begin{array}{l}\text { There was a wide gap here } \\
\text { with up to a } 2.5 \text { year } \\
\text { difference of time as an } \\
\text { apprentice }\end{array}$ \\
\hline 14 & $\begin{array}{l}\text { Learning (a) at work } \\
\text { (on-job) or (b) at } \\
\text { school/college/poly- } \\
\text { technic (off-job) }\end{array}$ & $\begin{array}{l}\text { All students were clear at } \\
\text { what level they were } \\
\text { studying }\end{array}$ & $\begin{array}{l}\text { A good understanding of the } \\
\text { requirement and level as to } \\
\text { what they were currently } \\
\text { studying }\end{array}$ \\
\hline
\end{tabular}




\begin{tabular}{|c|c|c|c|}
\hline $\begin{array}{l}\text { Question } \\
\text { number }\end{array}$ & Topics & Summary & Significance \\
\hline 15 & $\begin{array}{l}\text { Time to complete } \\
\text { level } 4 \text { qualification }\end{array}$ & $\begin{array}{l}\text { A comprehensive number } \\
\text { of topics had been studied } \\
\text { during their } \\
\text { apprenticeships }\end{array}$ & $\begin{array}{l}\text { A wide coverage of } \\
\text { engineering and electrical } \\
\text { topics had been achieved }\end{array}$ \\
\hline 16(a) & Plan for further study & $\begin{array}{l}\text { A number of students said } \\
\text { that they would complete } \\
\text { their level } 4 \text { training and } \\
\text { apprenticeship } \\
\text { Others indicated that they } \\
\text { would become registered. } \\
\text { A few said that they } \\
\text { would go higher to } \\
\text { Diploma level and some } \\
\text { wanted to travel overseas. }\end{array}$ & $\begin{array}{l}\text { Most students said that they } \\
\text { would finish their } \\
\text { apprenticeships and graduate } \\
\text { as a tradesperson with some } \\
\text { planning to gain higher } \\
\text { professional qualifications }\end{array}$ \\
\hline $16(b)$ & $\begin{array}{l}\text { Apprenticeship } \\
\text { contribution to plan }\end{array}$ & $\begin{array}{l}\text { All students gave positive } \\
\text { comments re their } \\
\text { apprenticeship to improve } \\
\text { opportunities and to } \\
\text { become qualified }\end{array}$ & $\begin{array}{l}\text { Very positive comments re } \\
\text { apprenticeships }\end{array}$ \\
\hline
\end{tabular}

*NZ Pakeha: A term often used to denote non-Maori New Zealanders (King, 1985).

In this group, nine students had not previously studied as pre-apprentices but had gained work experience mostly in the electrical and refrigeration industry, with a minority in other industry areas. One significant factor was that most of the apprentices in this group were adult apprentices. It became clear that the time spent at a workplace was considerably different amongst these apprentices: from one apprentice who had spent 8 months at their workplace to some with 2.5 years' experience before attending a block course. However, as most of the respondents had not previously been pre-apprentices, it appears that the average time spent as an apprentice was 1.5 years prior to studying on a block course as a second year apprentice. For this group, when asked where most of their learning had taken place, responses indicated that 11 students had learned more on-job at the workplace. Two apprentices indicated they had learnt equally from the workplace and from study away from the workplace at an ITP. The group identified with a comprehensive list of subjects they had learned over their time as apprentices, and they were clear as to what was required of apprentices in this industry. With regards to career direction and future pathways, the students were positive that an apprenticeship was the best option. They believed an apprenticeship would lead them to a higher position as a 
tradesperson. A few apprentices indicated after that their apprenticeship they would most likely move on to higher qualifications with advanced training, and possibly to a professional level with a diploma in engineering.

\subsubsection{Case Study 4: Apprentice students-Automotive.}

Case Study 4 consisted of 11 automotive industry apprentice students who were studying part time in the automotive apprentice program towards their New Zealand national certificate at level 3 . Their study required them to carry out at least $80 \%$ of their training and assessment through on-job learning. They were assessed by on-job assessors through an on-job assessment manual supplied by the Industry Training Organisation (ITO). For their off-job learning, the other $20 \%$ required them to complete specific theory/practical skills training for the workplace at an ITP. This was done via block courses and evening classes.

Table 4.8 shows the background demographic data and statistics for the students in the automotive apprentice cohort.

Table 4.8: Background demographic data for apprentice students: Automotive

Apprentice students: Automotive

- Number of students and year left school:

2 in 2002, 1 in 2003, 1 in 2009, 2 in 2010, 2 in 2011 and 3 in 2012

- Student age group:

5 aged $16-20,3$ aged $21-25$, and 3 aged 26 and over

- Ethnic background:

New Zealander (European) x 4, Fijian x 1, Indian x 1, Maori x 2, Pacific Islander x 3

- Qualifications achieved:

National Certificate in Educational Achievement x 5, School Certificate x 1, and other certificate $\times 6$, and NZQA qualifications $\times 2$

From the 11 apprentices interviewed, six were aged over 21 with five younger than 21 years of age. The ethnic mix in this group included four apprentices who identified as New Zealanders, one Fijian Indian, one Indian, two Maoris and three Pacific Islanders. From the 11 apprentices, only two had pre-apprenticeship training prior to becoming an apprentice. 
Table 4.9 shows the participants questionnaire summary for the students in the automotive apprentice cohort.

Table 4.9: Participants' questionnaire summary for apprentice students: Automotive

\begin{tabular}{|c|c|c|c|}
\hline $\begin{array}{l}\text { Question } \\
\text { number }\end{array}$ & Topics & Summary & Significance \\
\hline 6(a) & $\begin{array}{l}\text { Work experience } \\
\text { (jobs) prior to } \\
\text { starting the course }\end{array}$ & $\begin{array}{l}\text { Work experience } \\
\text { previously gained was all } \\
\text { from automotive work } \\
\text { places }\end{array}$ & $\begin{array}{l}\text { A very clear indicator that there } \\
\text { was no other work experience in } \\
\text { other areas and was all gained in } \\
\text { automotive workplaces }\end{array}$ \\
\hline $6(b)$ & $\begin{array}{l}\text { Working part time } \\
\text { or full time }\end{array}$ & $\begin{array}{l}\text { All students worked full } \\
\text { time }\end{array}$ & $\begin{array}{l}\text { Very clear that the majority of } \\
\text { work that was currently listed } \\
\text { was in a full-time capacity }\end{array}$ \\
\hline 7 & $\begin{array}{l}\text { Jobs before } \\
\text { starting the course } \\
\text { or currently } \\
\text { working full or } \\
\text { part time }\end{array}$ & $\begin{array}{l}8 \text { students had previously } \\
\text { full time related work } \\
\text { with } 3 \text { just casual work }\end{array}$ & $\begin{array}{l}\text { Majority of the students in this } \\
\text { group were employed in full- } \\
\text { time work that was not directly } \\
\text { related to the automotive } \\
\text { industry, but had some } \\
\text { relationship to engineering, with } \\
\text { a minority engaged in non- } \\
\text { engineering work }\end{array}$ \\
\hline 8 & $\begin{array}{l}\text { Employment } \\
\text { relates to current } \\
\text { study }\end{array}$ & $\begin{array}{l}\text { All respondents worked at } \\
\text { a job related to their study }\end{array}$ & $\begin{array}{l}\text { A very clear indicator that all of } \\
\text { the respondents were working } \\
\text { towards their apprenticeship } \\
\text { completion in the automotive } \\
\text { trade }\end{array}$ \\
\hline 9 & Apprenticeship & $\begin{array}{l}\text { All respondents worked } \\
\text { as apprentices }\end{array}$ & $100 \%$ apprentices \\
\hline 13 & $\begin{array}{l}\text { Topics learned } \\
\text { during } \\
\text { apprenticeship/pre } \\
\text {-apprenticeship }\end{array}$ & $\begin{array}{l}\text { All } 11 \text { students were in an } \\
\text { apprenticeship }\end{array}$ & \\
\hline 12 & $\begin{array}{l}\text { Current level of } \\
\text { training }\end{array}$ & $\begin{array}{l}\text { Out of } 11 \text { students } 9 \text { had } \\
\text { not studied as a pre- } \\
\text { apprentice leaving } 2 \text { that } \\
\text { had }\end{array}$ & $\begin{array}{l}\text { In this group the majority of } \\
\text { students had not completed a } \\
\text { pre-apprenticeship }\end{array}$ \\
\hline 14 & $\begin{array}{l}\text { Learning (a) at } \\
\text { work (on-job) or } \\
\text { (b) at } \\
\text { school/college/ } \\
\text { polytechnic (off- } \\
\text { job) }\end{array}$ & $\begin{array}{l}\text { All students were clear at } \\
\text { what level they were } \\
\text { studying }\end{array}$ & $\begin{array}{l}\text { Very clear where the level was } \\
\text { pitched at }\end{array}$ \\
\hline
\end{tabular}




\begin{tabular}{|c|c|c|c|}
\hline $\begin{array}{l}\text { Question } \\
\text { number }\end{array}$ & Topics & Summary & Significance \\
\hline 15 & $\begin{array}{l}\text { Time to complete } \\
\text { level } 4 \\
\text { qualification }\end{array}$ & $\begin{array}{l}\text { A comprehensive number } \\
\text { of topics had been studied } \\
\text { during their } \\
\text { apprenticeships }\end{array}$ & $\begin{array}{l}\text { A wide coverage of engineering } \\
\text { and electrical topics had been } \\
\text { achieved }\end{array}$ \\
\hline 16(a) & $\begin{array}{l}\text { Plan for further } \\
\text { study }\end{array}$ & $\begin{array}{l}7 \text { students said that they } \\
\text { would complete their } \\
\text { level } 4 \text { training and } \\
\text { apprenticeship } \\
\text { The rest did not know }\end{array}$ & $\begin{array}{l}\text { Majority of students said that } \\
\text { they would finish their training } \\
\text { and apprenticeship and graduate } \\
\text { as a tradesperson with some not } \\
\text { clear as to what they would do } \\
\text { for future plans }\end{array}$ \\
\hline $16(b)$ & $\begin{array}{l}\text { Apprenticeship } \\
\text { contribution to } \\
\text { plan }\end{array}$ & $\begin{array}{l}\text { Most students gave } \\
\text { positive comments re } \\
\text { their apprentice to } \\
\text { improve opportunities and } \\
\text { to become qualified }\end{array}$ & $\begin{array}{l}\text { Majority of students were clear } \\
\text { as to how the apprenticeship } \\
\text { would contribute to their future } \\
\text { plans }\end{array}$ \\
\hline
\end{tabular}

In the automotive apprentice group, nine students had not previously studied as preapprentices but had gained work experiences in the automotive or related industries. In this case study group, six of the apprentices were adult apprentices over the age of 21 and serving 2-3 years as an apprentice. As with the refrigeration/airconditioning/electrical students, most of the respondents had not previously been preapprentices - with an average time of 1.5-2 years spent as an apprentice.

For this group, the question about where most of their learning had taken place resulted in responses indicating that learning had occurred at the workplace, but that it needed to be improved. Study away from the workplace at an ITP was indicated as being beneficial. This group identified with a broad list of subjects that they had learned over their time as a current apprentice and they were clear as to what was required in the automotive industry. In terms of career direction and future pathways, the students were positive that an apprenticeship was the best option for them, and that it would lead them to an advanced level as technicians. Others in the group said that once their apprenticeship was completed, a likely progression may be to a higher level with an engineering degree. 


\subsection{Findings from the Pre-apprentice Focus Groups}

This section analyses the data gathered from the focus groups and students' experiences as pre-apprentices in the refrigeration/air-conditioning/electrical and automotive trade disciplines. The key themes identified are related to pre-apprentices' learning experiences while studying at an ITP and at the workplace engaged in work experience. As indicated in the research methods chapter (Chapter 3), the questions that provided the framework for the focus group interviews were devised to align closely to the research sub-questions.

The relevant themes were captured and identified from the focus group responses and interview data. (See Appendix F and also Table 3.3 for interview questions.)

\subsubsection{Themes from Case Study 1: Pre-apprentice students—Refrigeration/air- conditioning/electrical}

The following themes arose from Case Study 1: Refrigeration/airconditioning/electrical.

\subsubsection{Practical learning activities}

When asked about the most satisfying things in the pre-apprentice training program, the most common theme from students in the refrigeration/air-conditioning/electrical groups was that the practical sessions rated highly. In particular, responses relating to the practical based projects were very positive where students were required to work on projects as part of their practical learning program. These projects consisted of designing and assembling air-conditioning units and gaining fabrication skills. For example, comments from one focus group included:

"Putting the learning into practice—hands on practical— doing stuff."

"Learning the basics through practical projects—-building and working on air conditioning units. Understanding the theory through practical tasks on electrical units, and doing fabrication tasks in the workshop."

The majority (over 90\%) of the pre-apprentice students stated that they were provided with a substantial knowledge and skill base in preparation for the workplace. They had 
gained considerable value from the training and had learnt practical skills which gave them confidence to use these skills more effectively at the workplace. The practical workshop was seen as being very effective and beneficial in providing additional proficiency in tools and equipment. Students stated that the learning that they had undertaken was extremely valuable. This was reflected by such responses as:

"Having training with hands on practical work and using tools not known and used previously."

\subsubsection{Challenging issues}

For the question on difficult or frustrating issues, there was consensus regarding the time management of certain sessions where there were clashes for available classrooms and suggestions that there should have been more practical projects. There were issues pertaining to the number of projects available and the tools available to effectively carry out the project work. Comments relating to the practical work indicated there was insufficient theory to relate to practical application. Some students referred to insufficient practical sessions, for example:

"Finishing too early on projects, need more projects and more practical, not enough tools, and the tools that we had were in bad condition."

"Should be more integrated learning - theory and practical combined so as to better understand the theory."

There were mixed opinions on the theory practical mix. A number of students suggested that the theory practical mix was well proportioned, but others wanted to spend more time in the workshop. It was evident that the time allocated for project completion was insufficient, which proved to be frustrating as the students gained substantial value from the practical project work. The older students within the groups indicated that for them the practical aspect of the training was particularly useful as they were able to relate very well to the hands-on application.

\subsubsection{Learning methods}

Pre-apprentice programs were signalled by the pre-apprentices as being a method of training that suited them as full-time students, rather than becoming an apprentice direct at the workplace with little or no training into employment. Students enjoyed 
the facilities, teaching and resources at the Institute and were given the opportunity to explore the trade options to take an appropriate career pathway.

"The course provided a substantial knowledge and skill base in preparation for the workplace."

"Good grounding in all aspects of electrical and refrigeration and air-conditioning work."

The pre-apprentice students were very clear that through achieving success with their pre-apprentice program, the time it would take to complete an apprenticeship would be substantially reduced due to the credits they would have acquired. The students also stated that the courses studied provided a substantial knowledge and skill base in preparation for the workplace.

The responses to the question on how the program could be improved in terms of learning highlighted a need for further practical training to take priority. At the time of the three focus groups, six students were unhappy with the amount of electrical practical sessions that they had received during the program to date.

"We have only had 3 electrical practical sessions so far and were behind with the topic and haven't been in the workshop".

It became clear that for those students, electrical practical classes had not been available for the period of time they had been studying, and there were definite issues with the delivery and timing of practical sessions.

Other skills that students felt had not been available during their courses included skills related to communication, which were a necessity when attending their work experience component. When it came to delivery of the theory material, the students indicated that the delivery would be better placed by matching up the practical work instead of delivering parts of the theory in isolation.

\subsubsection{Work experience}

Pre-apprentice students had the opportunity of attending work experience and gaining hands-on practical experience at the workplace. For the students in Case Study 1, an important aspect of their experience was having the opportunity to learn from other staff at the workplace, and by gaining practice, for example, in installing air- 
conditioning units. It also became clear that by attending workplaces, possible employment opportunities were available once students had completed their preemployment programs. Prospective employers were able to evaluate the potential apprentice before deciding whether to employ them at the conclusion of the program.

The majority of students undertaking work experience in this group found that workplace training was worthwhile, as they learnt a lot from the technicians and workers there. Responses from a number of students indicated that practical learning at the Institute was essential for them to be able to carry out their work experience in the workplace.

"The learning on the courses complements the work experience and would be very difficult to carry out without."

"Training is excellent at the workplace and I learnt a lot from certain people working there."

The findings supported the notion that it was beneficial for the pre-apprentices to gain considerable hands-on practical experience prior to entering the workplace. This reassured them about the skills, tools and equipment needed at the workplace. Some further comments clearly indicated that for practice based learning, activities that occurred away from the workplace were useful:

"Learning how to use tools and knowing what to do in the workplace."

However, arranging work placements was left to the students, and there were some difficulties for a number of pre-apprentices in gaining work experience. Arranging work placements proved somewhat difficult, and as a result, a lot of time was spent trying to source a workplace to attend. The responses given all indicated that work experience should be a compulsory component of the program and should be arranged by the Institute and incorporated into the program.

"There is no on-job work placements arranged by the Tech, should be part of the course."

Others thought that an idea to improve the work experience component could be for the Institute to invite employers to visit prior to the work experience placements, to explain to the students their expectations of what students would be doing at the 
workplace and to enable better associations with the employers. When some of the students had been at the workplace, they found that it was not always easy to carry out some of the work.

"Sometimes we get help but it may depend on how busy the tradesmen are."

When asked about the skills involved in being a good tradesperson, students mentioned a real need to be safety conscious and to apply good, safe work practices. Clearly important attributes included customer service, people and communication skills. It was evident students had gained a good sense of what was required at the workplace through their workplace experience. For some students, the importance of practising their timekeeping skills was evident. These students attended the workplace on time and were punctual when signing in to work. For other students, their presentation concerning dress and manner when talking with others at the workplace had become important, as well as ensuring they were aware of the culture and work attitudes.

\subsubsection{Assessment}

There were mixed responses relating to the theme of assessment pertaining to the refrigeration projects where holistic assessment was used. These projects required the students to assemble all the components of a refrigeration unit, to test the completed refrigeration unit, to diagnose any faults indicated and to rectify the unit for correct operation. About half the students said that the assessment process worked effectively and was appropriate. Students liked the way that assessment formatively checked how much they understood the knowledge and skills they were taught. They were also able to re-sit parts of their assessment that were not correct and were assured that they were on the right track to achieving their final summative assessment.

"Felt the assessment asked all the necessary questions and was able to answer the theory assessment."

"The theory tests were good and the supervisor makes sure that the assessments were completed along the way." 
"I was able to achieve both the written and practical assessment tasks."

"Marry up the theory with the practical assessment combining the theory with the practical assessment."

Thus, a number of respondents indicated that the assessment process worked well for them, providing good formative assessments to check their learning. However, the comments indicated that students believed that theory tests pertaining to electrical subjects should have been integrated and timed more effectively with the practical assessment tasks.

\subsubsection{Expectations of the pre-apprentice program}

Overall, the comments relating to the benefits of the pre-apprentice program in this domain (Case Study 1) were very positive, including how the program provided a substantial knowledge and skill base in preparation for the workplace. The data indicated that confidence was boosted through what the students learned in the program that then helped them to search out an apprenticeship.

"The course is good because it's what we are training for in the future, to get a job as an apprentice. An apprenticeship will be easier to get once I have completed the pre-trade program.”

"It will give me a leg up to an apprenticeship."

"Get a head start in the trade and know what to do in the workplace."

It became clear for the students that being a pre-apprentice gave them an opportunity to meet others and gain some insight into what apprentices were doing at the workplace by working with them on real jobs. It was mentioned that through achieving success with their pre-apprentice program, the time it would take them to complete an apprenticeship was reduced. They indicated that if they had not attended the program, it would not be possible to complete their apprenticeship within a threeyear timeframe.

The students' mentioned some program areas that required improvement. Some commented that there could be more encouragement, for instance, identifying goals and career options at the conclusion of the program. 
"Better communication on what's going to happen after the program, someone from industry should come in and motivate students on the program."

"Staff should inform students more about apprenticeships within the program."

By providing improved information to the students, a clearer impression would be given regarding apprenticeships and what the requirements for work are. The participants felt more could have been done to support work-safe activities where instruction had been limited within the program. (When accessing construction sites in New Zealand, it is recommended that workers have a site safe certificate endorsed by the New Zealand Qualifications Authority.)

\subsubsection{Themes from Case Study 2: Pre-apprentice students-Automotive}

The following themes arose from Case Study 2: Automotive.

\subsubsection{Practical learning activities}

There were similarities between the automotive (Case Study 2) and refrigeration/airconditioning/electrical (Case Study 1) pre-apprentice groups relating to satisfying program aspects. For example, very positive comments were made from all 14 students in Case Study 2 pertaining to hands-on practical learning both at the Institute and in work experience. Examples included:

"Thoroughly enjoyed the hands on practical part of the course, learnt a lot of practical skills and will be able to use scan tools at the job, all the practical learning and using tools never used before."

"Learning the basics and doing practical, working on equipment, hands on skills, and gaining a good working knowledge of automotive."

Comments from the participants indicated that the courses were very enjoyable and the knowledge gained was of enormous value. By learning the required practical skills and using technical test equipment the students indicated that they were better prepared for future employment in the motor industry.

\subsubsection{Training methods}

There were very positive comments relating to program strengths that enhance capability for current practical work requirements. Students felt they had gained 
substantial skills that were beneficial to them when it came to putting their training into practice and that were considerably useful at the workplace. They believed gaining such skills gave them a significant advantage and they were able to carry out the required tasks with much more ease.

"The teaching on the course is very good and will continue to complete level 4 qualifications."

"Gained enormous understanding of knowledge and practical skills."

By learning advanced skills on the program, students were of the opinion that they now had a very good working knowledge of automotive practice, as well as technical and people skills that could possibly lead to owning and operating their own automotive workshop in the future. The students indicated that for work in diagnostic areas they were proficient in using technologically advanced scan tools, and were more knowledgeable than some technicians at the workplace in the use of such equipment. In some instances they were able to help others determine how to utilise specific testing tools.

Additional issues that were discussed related to the number of practical and theory classes that were held. Some students believed there should have been more formal classes to cover the topics within the courses. For blended learning, further opportunities using this method of delivery was lacking due to limited technology and access to Internet connections. This was seen as an issue as some of the teaching and learning access was through the student and learning online system.

\subsubsection{People skills}

The question relating to tradesperson skills also brought out similarities between the case study groups pertaining to skills that were seen to be essential, for instance, people skills relating to team work, and working unsupervised in a work environment. Communication and customer service skills were again mentioned as critical in aspiring to the level of service manager in automotive engineering. 
"I gained good knowledge to be able to go into the workplace."

"I was able to gain a lot more confidence, and learnt diagnostic skills."

"Safety skills, customer service skills, public relationships, punctuality, presentation, communication skills not taught on the course."

Here students believed that additional tuition was needed on communication skills and an understanding of the requirements in the workplace, as this topic had not been taught within the program.

Students indicated that having the correct work ethic was important, including punctuality and the correct attitude to attending the workplace and working in general. It was also vital to be able to "self-learn" in order to become more knowledgeable.

\subsubsection{Work experience}

A number of students had worked in the industry and the consensus was that working at the workplace was extremely valuable. Students also indicated that automotive technicians were particularly good to work alongside and were very helpful if any questions were asked about the work.

"It is good to work alongside a mechanic and the mechanic will give me a job to do, and I was able to ask anyone in the workshop about the work."

At the workplace, the respondents found that the mechanics were very happy to explain how work was organised and what was required of the students when work was to be completed. The students also felt that being a pre-apprentice and gaining knowledge and practical skills at the Institute was invaluable in order to carry out tasks at the workplace.

"I learnt from tutors at the Tech and put all the learning into practice at the workplace."

For the majority of automotive students, there was no issue to finding work experience. They indicated that attending the pre-employment program and carrying out workplace learning also helped them to secure possible permanent places in the industry as an apprentice. 
"It would be very different without doing the course at Tech - the learning at the Tech complements the workplace learning."

For a minority of students intending to work as an apprentice, prospective employers required them to enrol in and complete a pre-apprentice program. Achieving a job in industry was clearly seen as the main benefit of attending a pre-apprentice program. In addition, the training towards their qualifications and achieving credits were perceived as being an advantage to their career path.

In terms of on-job training and working in the automotive trade, 11 participants indicated that they currently had work in the trade in a part-time capacity and were most likely to take up full-time work in the industry on completion of their preapprentice program. It appears that for some students the employers engage in on-job training and work with them to complete particular jobs at the workplace. Other students worked with the mechanics and watched and learned from them as they carried out repairs on vehicles within the workshop environment.

A few students also made negative comments regarding work experience opportunities. They considered that the Institute could do more to assist in finding employers and industry places for students to gain work experience.

"MIT should assist with finding work experience as work experience is very difficult to find for students."

A good proportion of the students found that organising and finding work experience proved very difficult and not all students were able to locate and arrange places at the workplace. From the comments made by the respondents, it was an issue that needed to be remedied, as some students believed the work experience should be fully organised by the Institute and made a compulsory part of the program.

A question about the amount of training that occurs at the workplace was seen as an area that could definitely be improved. A number of students felt that although there was some training carried out, it was insufficient. 
"We do get some training at the workplace but it is not good enough."

Some students were unable to complete any training at the workplace, and were relying on the Institute to assist them to find employers prepared to take them on to gain work experience.

\subsubsection{Assessment}

For the automotive students, responses regarding assessment were very positive and the students felt that the assessment process worked effectively. They appreciated the fact that the assessor was firm and made sure that the assessments were effectively organised and appropriate.

"The tutor separates students, and makes sure that you do assessment on your own."

Students realised that assessment formatively checked how much they understood along the way, and they were able to carry out re-assessment for parts of the assessment that were incorrect to ensure they were on the right pathway to achieving their final summative assessment.

"It is good to check out how much we know-it's the only way to go."

"If we fail some parts of the assessment we can do up to 2 re-sits to complete the assessments."

In terms of their practical assessment, students were very supportive of the way that the assessor asked questions throughout the assessment process.

"Practical assessment is ongoing and tutors ask questions throughout the assessment process, and the task sheet—works well."

The practical tasks were achieved through an ongoing process and students felt that the task sheet worked well and was easy to follow and understand.

For the question on assessment, some minor issues were highlighted, for instance, there was some confusion about what questions on theory assessment were actually asking. There needed to be a lot more clarity in regard to the questions and some redevelopment to ensure that for future students the theory assessment would be understood. There were suggestions that assessment could be improved by introducing 
a different model, where assessment could include achievement standards, and be graded and show merit passes for excellence. However, the current assessment process is arranged as competency based only and merit passes cannot be included as the assessment criteria is determined by the New Zealand Qualifications Authority.

\subsubsection{Expectations of the pre-apprentice program}

The automotive pre-apprentices understood that completing their full-time program was a worthwhile experience as the knowledge gained was essential. They indicated that just working at the workplace was "not good enough"; instead, they needed to know the "why and what do things mean". Students expressed an essential need to learn diagnostic skills and techniques to be able to rectify problems when they were at the workplace. By attending a pre-apprentice program, employers were also more likely to offer an apprenticeship on completion.

"Yes lots of industry work places want pre-trade students."

"Learning is time well spent and far better than doing nothing at all."

Overall benefits indicated included the opportunity to gain "hands on practical work" and to use tools not previously known or used. Further benefits related to completing the theory units towards their qualification, and students believed that once employed, these apprenticeship learning units would be necessary. Other benefits cited were that if they had declined to study the pre-apprentice program, access to work prospects and job leads from the lecturers at the Institute would be unobtainable.

Students indicated a few areas that could be improved on, for instance, when searching for a job at the completion of the program, further assistance from the Institute on career planning and curriculum vitae writing would be beneficial. Other suggestions to improve job opportunities included receiving support from staff and the Institute in actually finding an apprenticeship.

"We need help to find an apprenticeship — and the institute should build 1 week into the course for that very purpose."

There were some positive suggestions as to how the pre-apprentice program might be improved in future, including incorporating a "how to find an apprenticeship course" component. Improved employer advertising and marketing was also suggested to 
engage employers in sourcing potential apprentices for the workforce. These were strategies that might improve the job prospects for students looking for an apprenticeship.

\subsection{Findings from the Apprentice Focus Groups}

This section analyses the data gathered from the apprentice focus groups on their involvement in the two trades identified (refrigeration/air-conditioning/electrical and automotive). It also categorises key themes related to their learning experiences as apprentices when at the Institute and at the workplace.

Similar to the pre-apprentice section, the theme tables were arranged from the focus groups transcriptions and linked to the main research questions. From the data collected, key themes were identified and have been detailed in the following findings.

\subsubsection{Themes from Case Study 3: Apprentice students—-Refrigeration/air- conditioning/electrical}

The following themes arose from Case Study 3: Refrigeration/airconditioning/electrical.

\subsubsection{Practical learning activities on-job}

The refrigeration/air-conditioning/electrical apprentices indicated that being an apprentice was very satisfying. A number of comments related to learning on the job and getting paid to learn whilst at the workplace.

"When working I am able to study and can put the learning into practice."

"Able to do stuff and learn new skills and take on challenges."

"Sometimes we can get lots of training at the workplace and learn well on the job."

However, some students indicated that sometimes learning on the job was intermittent and depended on the workplace and their "boss". Others found that training at the workplace took the form of more dedicated training and that: 
"The boss has very high standards and makes it a priority to help you get through your apprenticeship."

It was clear from the data that a majority of apprentices found that learning on-job was a good experience and was well supported by employers. Conversely, significant difficulties were highlighted by other apprentices in completing on-job requirements at the workplace. There were issues related to the scope of work at the workplace, and that the training available was insufficient and subsequently led to issues of completion.

\subsubsection{Learning methods}

Training in industry was quite different across workplaces. While some students found training at the workplace to be of good value, others indicated there were challenges to learning at times, for example, it was difficult to ask questions of tradespeople. Conversely, constructive reasons for being an apprentice were given showing a preference to studying on a full-time basis rather than as a pre-apprentice.

"Completing the on-job requirements and matching up with the correspondence study."

Other comments indicated that by completing the training at the workplace the timeframe was a maximum of three years, and by working as an apprentice it was possible to meet up with other apprentices at the workplace and compare their training progress. It was stated by three apprentices that by working as an apprentice definite benefits included understanding the diversity and requirements of the industry.

"It is better than studying full time and then going out to try and find a job after a full time course."

Of the apprentices surveyed in the refrigeration/air-conditioning/electrical groups, only four had completed a pre-apprentice program prior to working as an apprentice. The overall comments from the non-pre-apprentices indicated that they preferred to work full time and to study part time. The four ex pre-apprentices thought the opposite and believed that completing a pre-apprentice program was the preferred option.

The apprentices found that the time allocated for their off-job training was insufficient. Only two weeks per year was provided which was not enough to 
complete the practical requirements on block courses. Apprentices were aware that the timeframe had been substantially reduced due to funding constraints, which in turn restricted the amount of learning occurring. Additional issues indicated were that some subjects carried out at the Institute were thought to be irrelevant and should be removed from the syllabus.

Key components of training in the workplace were identified as being issues, including the need for some employers to embrace training as an important function. There were high expectations for some apprentices who were shown requirements for tasks only once and then expected to know how to complete the activity. Also identified was the need for cooperation between apprentices and the training organisations to ensure that quality training was conducted efficiently. A minority of employers were alleged to not be carrying out effective training. Some apprentices found it hard to know how to complete a training plan at the workplace, as training plans had not been explained in detail to them by the training manager.

Four apprentices acknowledged that there were difficulties in actually being apprentices, for example, the nature of their treatment at the workplace was not conducive to learning as some of the work required was menial and demeaning. For other apprentices, prior to starting as apprentices, employers had recommended that work experience was the best option.

"Some apprentices get thrown into the deep end and told to work it out for yourself."

A number of issues were associated with trying to learn technical skills from qualified and skilled tradespersons at the workplace, as there were some difficulties understanding the technicians due to language barriers. Responses indicated that employers have high expectations for apprentices being able to complete certain tasks without adequate prior training. Conversely, there were a number of ideas suggested as to how an apprenticeship might be improved, including some encouraging thoughts as to how employers could make changes to improve quality training at the workplace. For instance, on-job training could be improved by providing suitable trainers/assessors. Changes may also include improving additional scope of work at the workplaces for apprentices to complete on-job assessments. In terms of the training courses apprentices were obligated to complete, there was agreement that 
there was definite room for improvement. For instance, there was disparity between students' current training and knowledge. Students were enrolled onto courses with wide differences between their levels of capabilities within the same courses.

"Up to three years difference in the trade compared to newbies."

Students indicated that the ITOs need to clarify with apprentices the correct year off study undertaken as the ITO controls the apprentices' training plans. When new students were enrolled into the same courses with more advanced students from a higher year, it was very difficult to ensure consistency with course delivery.

\subsubsection{Expectations of the apprentice training courses}

The majority of employers interviewed who had taken on pre-apprentices were of the opinion that apprentices who had previous pre-apprentice experience were usually more motivated to learn, and more prepared for the workplace, compared to those who had not done pre-apprenticeship courses. However, apprentices engaged directly into the workplace believed that they had learnt a wide range of skills to meet the requirements of the trade. For them, an apprenticeship was seen as beneficial and they preferred to study through part-time courses to gain the required job knowledge.

The theme on expectations clearly showed that there were a number of areas that required improvement to provide a better learning program for apprentices in the refrigeration discipline. For instance, in terms of communication between the ITOs and ITPs, apprentices at times were not informed about training issues and believed there was significant room for improvement. Apprentices suggested that the curriculum required amendments for learners when attending off-job and also on-job learning. For instance, in the distance learning package:

"There should be improved comments written on assignments by assessors (one assignment had weird notes) and was hard to understand."

Some respondents said that when carrying out off-job assessments it would be beneficial for no more than one assessor to mark assessments to provide consistency. To carry out diagnostics and servicing of equipment, there is also a need for further training in learning troubleshooting skills. For quality assessment to occur at the workplace, suggestions included the Institute providing a trained on-job assessor for 
workplace assessments, instead of using supervisors employed at the workplace as assessors, as they were not always available due to other commitments.

Other comments were made relating to pay and travel to courses:

"Pay for travel and accommodation when travelling to block courses should be made available."

"Distance was a major concern to attend training courses and on-line training would improve the learning experience."

Apprentices were of the opinion that when attending training courses, insufficient resources were allocated for travel and accommodation. A number of apprentices in this field travelled long distances to attend courses and were required to fund their own expenses. Further comments suggested a need for apprenticeship block courses to be increased from the current two weeks' duration to provide additional training and assessments.

Responses indicated that the workplace environment required improving. For instance, being an apprentice was seen by other workers as being inferior.

"As an apprentice you have to do everything, you have to do the whole job on your own and when you have no support from the workers at the workplace it is hard on you, it's the worst part of the apprenticeship."

Comments about working as an apprentice with allocated jobs were identified as frustrating and not an enjoyable component of being an apprentice. The responses indicated that support was not forthcoming from tradespeople at the workplace and that the apprentices felt isolated.

\subsubsection{Assessment}

A number of apprentices said they had not completed any on-job assessment since starting as an apprentice. This was significant as these apprentices were studying at level 3 which was at least more than one year of employment. The expectation for onjob assessments is that level 2 unit standard requirements are usually completed in their first year as an apprentice. They indicated that for assessment to be arranged and completed the correct job had to be available. One or two students experienced 
frustrating issues when attending off-job training block courses, for instance, shortages of assessors available to carry out assessments.

When considering the distance learning program that the refrigeration/airconditioning/electrical apprentices were contracted to complete as their theory component, the program also included knowledge based assessments that the students were required to achieve. They needed to pass each level at 1-4 on the New Zealand National Framework to pass their national qualification. Concerns were voiced regarding their distance learning, particularly regarding the assessment and marking of assignments such as a lack of urgency for marking assessments within a suitable timeframe. Alternatively, assignments were sometimes getting lost in the postal system. Apprentices indicated that some of the correspondence information they received was not relevant to the assessment.

"Some of the workbooks were difficult to work with i.e. some of the questions not related, questions badly written. The timeframe needs improving for the return of the correspondence books when the marking had been completed."

As apprentices stated, theory assessments incorporated into the distance learning material proved inadequate, and improvements were required to update materials and mark assessments in order to return them to the apprentices in a suitable timeframe.

For on-job assessment requirements it was shown that on-job assessors are employed by the employer; comments made by a number of students alleged a conflict of interest. There was a belief that some assessments were just signed off as the "employers knew what the apprentices were able to do, so they just signed assessments off'. Some assessments were believed to be invalid, for example, out of date and not relevant, and too many optional units were required to be achieved to pass the assessments. Many of the apprentices had not been seen by their on-job industry training managers (employed by the ITO) to ensure they were keeping up with their training plan. It was alleged that industry training managers were only seen by apprentices up to three times over a one-year period. 
"Training managers should carry out assessment but in most cases they were not seen at the workplace. Training managers may be only be seen by some apprentices three times during a year."

"Some employers will help explain the learning required, but some will not and some apprentices had no on job assessments and have to wait until a certain job comes in to the workplace."

The concern identified here was that when the training managers were absent there was a lack of training events occurring, which in turn led to apprentices falling behind in their achievement of credits towards their qualification. To achieve on-job assessments at the workplace sometimes proved to be difficult as the work was not always available.

\subsubsection{Themes from Case Study 4: Apprentice students-Automotive.}

The following themes arose from Case Study 4: Automotive.

\subsubsection{Practical learning activities on-job}

For apprentice automotive students, the most satisfying parts of their training program were practical training, study off-job away from the workplace, and learning new knowledge and skills across a range of vehicles. The workplaces that the apprentices were employed at ranged from small workshops with up to five technicians to medium sized franchise workshops with up to twenty automotive technicians employed.

Getting paid was perceived as a bonus when working and learning and receiving pay increases when achieving competency throughout their apprenticeship. As far as being a good tradesperson was concerned, highlights included the need to gain good practical hands-on experience working with engineering and materials, and ensuring that all work is carried out in a safe manner that meets industry standards, including safe operation of hand tools.

"I developed new skills in fault finding and diagnosis and repair techniques and learnt new methods of using different scan tools when diagnosing car problems."

The need to learn electrical and electronics systems were stated as being important skills to learn in order to work with new and emerging technologies in electrical and 
hybrid vehicles. Other key skills to learn as a tradesperson were the need to understand and develop car diagnostic skills to repair modern vehicles.

Automotive apprentices saw training conducted at the workplace as an important issue, and they indicated that at times training failed to occur due to a number of reasons.

"Have to work it out for yourself sometimes as they are too busy doing other stuff."

For instance, apprentices indicated that sometimes the workplace would get too busy and there was insufficient time for technicians who supervised the apprentices to ensure that training occurred on a regular basis. The training at the workplace was also seen as requiring better organising to coincide with the off-job training program. Comments were made regarding the opportunities within some workshops where the work was based on older model vehicles, and as a result, apprentices were not able to obtain work experience with later model vehicles.

\subsubsection{Learning methods}

Within the automotive trade it was indicated that "getting paid to learn" was a real benefit of training as an apprentice when working on-job and attending off-job training courses. Some apprentices said that learning new skills and finding new challenges was most satisfying for them.

"Learning was good when going to block courses as you found out much more about cars."

"Have built up more confidence from attending training and I feel okay if I fail at some tasks at block courses, and then get it right second time around. But when at the workplace cannot afford to get anything wrong as it is for real."

The apprentices saw practical training as essential, as part of learning within the courses was learning new subjects. 
"Engine rebuilding including clutches, hydraulics, oils and also electronics and electrical made working at the workplace a lot easier."

As a result of gaining particular practical training at the block courses, when apprentices returned to the workplace they were able to put the practical learning into real on-job experiences with enhanced confidence and ability.

Comments were made concerning the workplace as a training environment. Apprentices stated there was a lack of on-job training occurring due to a limited number of people at the workplace able to explain and provide knowledge. Other issues included inconsistencies regarding payment for attendance at off-job training courses. Not all apprentices received pay to attend, while other apprentices were required to take annual leave from work to attend training.

For other apprentices, understanding tradespersons' instructions proved difficult.

"I was put with tradesmen and required to watch and learn how things are carried out, but there is a language barrier and sometimes I find it hard to ask questions."

Others said that it mainly "depended on the mechanics" as to how the training occurred at the workplace and it also depended on the cars they had been trained on.

"Working on too many older vehicles and not keeping up with the latest cars."

"Latest Tech companies should come into the workplace more often to train mechanics on new training equipment and tools."

Further comments indicated that apprentices saw a need for more experienced technicians to visit workplaces to advise them about new technologies.

\subsubsection{Expectations of the apprentice training courses}

Benefits of attending training courses that were mentioned included positive feedback on opportunities to learn how things were accomplished. Apprentices also mentioned additional support and the knowledge that someone with advanced knowledge is available to assist if you are not sure how to accomplish certain tasks. 
"You know that you will be taught correctly."

"There is more explanation of knowledge as no one at the work place explains things and we are able to gain hands on practice."

"We have the ability to work with new tools and equipment."

As indicated, if mistakes were made apprentices were told it was okay and were given the chance to learn from them. It was also noted that when attending training courses the lecturers were able to spend considerably more time explaining operational aspects.

In regards to possible improvements within the automotive apprenticeship course, comments included improved workplace training, and improved support from the government and from the ITO. There was an expectation that more skills needed to be taught regarding topics with greater maintenance and supervision content. An important area cited was in the electrical and electronics field where there was a need to train on vehicles that were more "high tech", such as electrical vehicles and hybrid models. Recognition of prior learning was also indicated as an area requiring improvement.

"Through cross crediting from other trades to accelerate the training, and by getting recognition of prior learning towards the apprenticeship."

Additional options needed to be available for cross-crediting previous skills and knowledge. For apprentices, this would accelerate their training programs through recognition of prior learning after completing other areas of related work experience. It appeared there was no consistency when it came to employers.

"Some companies were good where others were not. Other employers were not giving opportunities for advancing with studies, and there needed to be improved training on the job. There needed to be extra block courses offered to gain units that are not available at the workplace, as some units are specialised and not available on-job."

Here apprentices were advocating that on-job training required attention, as employers within certain workplaces prevented opportunities for apprentices that would help in gaining their qualifications. 


\subsubsection{Assessment}

Four of the automotive respondents indicated that no on-job assessments were carried out, which was also identified by the refrigeration/air-conditioning/electrical apprentices as a significant concern given that the apprentices were studying a level 3 training course. Others indicated that for assessments to be arranged, the correct job needed to be available at the workplace for the assessment to occur. For some students, when they were required to attend their off-job training courses there was a lack of assessors available to carry out assessments.

\footnotetext{
"We should have more assessors to carry out assessment as we were waiting around for assessment to take place, as there is only one assessor for practical assessments."

"Time is too tight—crammed and not enough study time and covering two units in one day."
}

Frustrating matters that occurred with the training program included difficulties regarding the theory assessment and the timeframe for achieving the units. For instance, study time was insufficient when two assessments were required to be undertaken during the process of a day.

\subsection{Findings from the Interviews with Lecturers}

This section analyses the data gathered from the lecturers who were engaged in teaching the pre-apprentice and apprentice groups. This data was obtained through conducting individual semi-structured interviews. The lecturers involved with the study were all male and they had been teaching with the pre-apprentice and apprentice programs from 2-20 years (see Table 4.10). All staff had been involved with both types of programs and they were familiar with the teaching and assessment requirements in both disciplines. With the automotive pre-apprentice program, both lecturers were not teaching on the apprentice program at the time of the interviews, but had previous teaching experience with apprentices. It was considered unnecessary to differentiate between pre-apprentices and apprentices when interviewing the lecturers as all lecturers had considerable experience in teaching both groups of students in both disciplines. 
The interviews were designed to gather information from the lecturers teaching on the full-time pre-apprentice programs and the apprentice programs. The key aspects of the training focused on students studying at an ITP, and also at the workplace engaged in work experience or as an apprentice working full time. The interviews asked questions about quality of the training and whether the training could be improved, as well as questions on teaching and learning and how the different modes of training were viewed. Interview questions also related to learning and on-job and off-job assessment. A further aspect of the questions related to benefits realised for both modes of training.

The theme tables were arranged from the interview transcriptions relating to the key interview questions, and the themes from the quoted responses were analysed into respective groups and are listed below.

Table 4.10: Lecturers

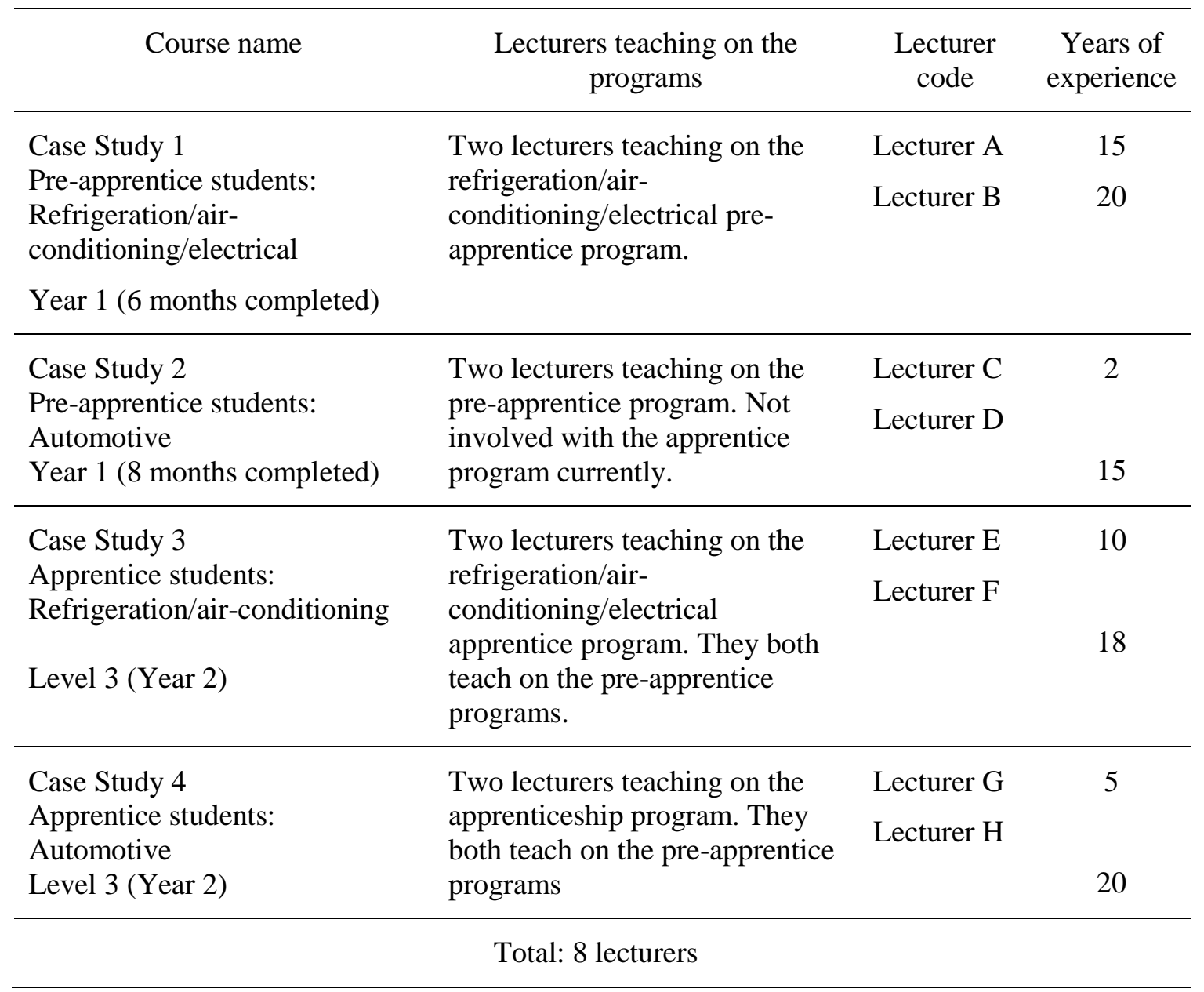




\subsubsection{Themes from lecturers}

The following themes arose from the lecturer interviews.

\subsubsection{Practical learning activities}

For the lecturers, the question regarding the most satisfying things about teaching apprentices or pre-apprentices included explaining the latest technologies and engaging students in practical hands-on learning. For instance, when engaging preapprentices in tasks on vehicles, small projects were undertaken relating to actual vehicle faults which the students would have to diagnose and work out how to remedy. There was notable interest by the lecturers in both disciplines in regard to researching new technologies that enhanced learning for the students.

Lecturer C: "The latest technology being explained and how to select correct tools and equipment to carry out in practice. The latest technology is always changing and being developed."

Lecturer G: "Questioning from students showing an interest in latest technologies and finding information to be able to diagnose and repair faults in vehicles."

For the automotive lecturers, it was of particular importance that the students were embracing new technologies that were a necessity within the workplace.

Practical project work in the refrigeration/air-conditioning/electrical discipline was seen as being advantageous where students were able to expand on previous skills gained earlier in the pre-apprentice program.

Lecturer F: "Broaden their understanding of their place in industry. Gained an understanding of tools that they can use when carrying out electrical work".

The project work enabled reinforcement of earlier prior knowledge and provided a clearer understanding as to how the skills gained were to be used in the workplace.

Lecturer E: "Students will gain a clear understanding of what they have learned when in the workplace."

Comments were made that satisfaction was gained from apprentices who enjoyed working in class groups, and sharing their experiences from the different workplaces that they had originated from. 


\subsubsection{Training}

The lecturers felt that benefits for off-job training included the training received by apprentices when engaged in integrated practical and knowledge activities. On their return to the workplace after their training courses, lecturers felt that apprentices were able to put their training into practice and show definite improvements in real work. This feedback was indicated by employers when lecturers visited industry as part of their industry engagement.

An additional benefit was, according to the lecturers, that pre-apprentice students gained a sound learning platform to build on for the future, not only towards their qualifications but also for industry when taking up employment there.

The question relating to the theory/practical ratio was agreed by all lecturers as being set at the correct level. However, it was determined by the lecturers that the best method for the delivery of most subjects was through an integrated process of theory and practical.

Lecturer H: "Most of the theory is taught from a practical aspect and the best delivery is to give an overview of theory and then go into the workshop and go through the theory in the workshop and carry out practical tests and proving tests i.e. cooling system thermistors and prove operation in the workshop therefore turning the theory into reality."

Through using this approach, the theory was more realistic. When assessments were required, students were also more prepared and able to negotiate the best time to complete the theory assessments following the practical application.

A similar form of learning to that of integrated learning was identified by one automotive pre-apprentice lecturer as a "spiral learning" technique, whereby learning a particular topic was introduced early within a course. As the learning was continued and extended through further knowledge and practice in that subject, by the end of the course the learning was reinforced ready for assessment to occur. 
Lecturer H: "Teaching through spiral learning, i.e. learning hydraulic theory and applied hydraulics, and other subjects including reconditioning engines and engine tuning."

"At the end of year this allows students to build on prior knowledge! Students enjoy that type of delivery where they can reinforce their learning from earlier delivery".

The courses were also seen to complement and provide a clearer understanding of how tasks were practised within the workplace and students' responsibilities when engaged there as apprentices. An important feature described by another automotive apprentice lecturer as a definite benefit for students was for them to be engaged with staff and to discuss in-depth material while attending a block course to gain a clear understanding of the curriculum.

Gaining qualifications by attending pre-apprentice training programs was a definite advantage for those students choosing to study on a full-time training arrangement.

Lecturer A: "Yes essential for students to gain qualifications outcomes. Great advantage to gain the national certificate in a shorter time. Undoubtedly current feedback is that the pre-apprenticeship training at MIT is the best in the country."

There were issues that needed addressing to improve the learning opportunities for the students, whether it was on a full- or part-time basis. Some of the issues identified included the quality and different modes of training.

Lecturer H: "Only thing is the equipment and the gear, should be updated. Some stuff is too old, more capital expenditure required across the school. Across the school, all equipment should be available for all. Should be a central store-own equipment there i.e. test equipment and resources."

Lecturer B: "Management requirements added unnecessary workloads. Premises in which we work in are too small and need to be updated to cater for the number of students that we teach."

From a majority of lectures in both disciplines it was determined that plant and equipment was dated and not up to specification with industry requirements. Additional investment in capital expenditure was required to upgrade the teaching capabilities and resources. 
Two lecturers from the pre-apprentice refrigeration/air-conditioning/electrical program indicated that changes that occurred at the workplace could be introduced to the off-job training courses.

Lecturer B: "Industry engagement-latest changes that occur at the workplace including new technologies to be brought into courses by industry personnel to introduce to trainees and pre-apprentices."

Lecturer A: "Industry visits - for all groups expanding knowledge to certain areas of study i.e. industrial commercial refrigeration."

Through the introduction of advanced technology within the training programs, students studying full time will have improved opportunities to gain expertise in diagnostic skills.

\subsubsection{Expectations of training programs and courses}

Lecturing staff agreed that students spending considerably more time engaged in fulltime study can focus entirely on their career paths before going into industry as an apprentice. Once working in a trade as an apprentice, students can no longer spend the same amount of time on their study component compared to a pre-apprentice student.

Lecturer C: "Students are fully trained during their pre-apprenticeship program and industry are always continually requesting for student recruitment from the program."

Employers evaluate the pre-apprentices to determine whether they would employ them or not, during and at the end of the students program. Lecturers indicated that once students have completed a pre-apprentice program, they have a far better chance of gaining employment as an apprentice.

Lecturer B: "It is important to complete a pre-apprentice program, and students gain an understanding of what they are required to do in the future. They have a choice as to what they will do before going into the workplace and this allows them to make up their mind as to where they stand within industry." 
Lecturer C: "Pre-apprentice programs provides students with a solid knowledge perspective on workplaces and they will be immediately productive, whereas in the past when starting an apprenticeship students were given mundane jobs to do such as sweeping the workshop floor, making tea and cleaning parts that were simple tasks and not helpful to gaining skills and knowledge in the motor industry. Now students enter the workforce as productive and work ready."

As part of the automotive and refrigeration/air-conditioning/electrical pre-apprentice program, students are required to carry out work experience with potential employers where they can show an employer their capabilities. The lecturers agree that this is one of the expectations for pre-apprentices. They may be taken on as an apprentice if they perform to a high standard when engaged at the workplace.

Conversely, lecturers commented, there is an adverse side to the work experience component, and in some instances employers may be over zealous to employ the students. Students may successfully gain employment as apprentices before the conclusion of the program. As a consequence, students may be unable to complete their program on a full-time basis. The New Zealand Tertiary Education Commission (TEC), acting on behalf of the New Zealand Government, states that students leaving programs are non- completers. This situation creates issues for the lecturers as the students leave the program without completing their qualification and are deemed to be unsuccessful. For the lecturers, this affects the success and retention of the program, as students leaving the program to take up apprenticeships are considered as a failed outcome. However, once employed as an apprentice, students' training will be continued, enabling completion of their qualification through an alternative pathway.

Additional benefits expressed by lecturers to students on full-time programs included more industry involvement with lecturers through an improved industry engagement plan, and industry visits for all student groups to allow for an expansion of knowledge in all areas of their study.

Lecturer A: "Work experience informs the learning that is carried out at the Institute. Students return back to the Institute after work experience and share their experiences from the workplace and relate the learning at the workplace to other students."

All lecturing staff involved in teaching pre-apprentice programs actively engages with industry, ensuring that students have the opportunity to spend time at work 
experience. Various workplaces provide opportunities for the students with on-job work practices.

\subsubsection{Assessment}

For the level 3 year 2 refrigeration/air-conditioning/electrical apprentices, a requirement of the block course training was to complete a practical project. As part of the practical project, summative assessment was integrated in the project and certain criteria were identified to measure the students' ability to complete all the components of the project. The lecturers indicated that the assessment gave very clear indicators of how the strengths/weaknesses were performed over the entire project. The final result of the assessment process was confirmed by the assessment tasks being accomplished through observations of the fully operational refrigeration working unit.

Lecturer F: "Happy with assessment as it stands, assessment is only a method of judgement, however delivery needs to change to allow the students to gain and own the knowledge. Better method than the assessment used at school."

Updating methodologies with regards to assessment could be seen as an advantage for learning. Suggestions were made that digital online learning could be used as an alternative method of providing assessment tasks.

Further suggestions made by some automotive lecturers to improve assessment approaches included modifying the way that the theory tests were conducted.

Lecturer C: "Negotiate when the theory test is to be offered and carried out through arranging practical assessment, and once completed then arrange the theory directly following the practical tasks as this method would work more effectively. The students would be more prepared to sit the theory assessment and have a better understanding of the theory once the practical assessment has been achieved."

Lecturer G: "Assessment should be dealt with (theory). Online assessment should be an option. There needs to be more industry involvement into theory delivery in some areas."

In doing so, the assessments would be more beneficial to the students with accurate timing of theory in relation to the practical activities. As determined by the lecturers, students would then be suitably prepared and equipped to be assessed on knowledge once the practical tasks were completed. 
Comments from the pre-apprentice automotive lecturing staff were positive in relation to the assessment process, and they stated that the methods used were complementary particularly when pertaining to the practical activities.

Lecturer C: "Three types of assessment, oral, formative and summative assessment. Practical assessment works very well- clear indicators of how the strengths/weaknesses are performed by the individuals."

Lecturer D: "Project based assessment works well and it's possible to see everything operating in total operation e.g. must operate and work at the end."

Through project based assignments students were able to identify closely with real work activities in the workplace. Lecturers believed that the advantages of projects are that the final outcomes exemplify operational features and demonstrate student capabilities.

Questions asked pertaining to assessment and whether the lecturers were pleased with the way that assessment was carried out, offered some interesting comments. For instance, there was a difference of opinion pertaining to the question of summative assessment. Explanations were given regarding the current requirement of the theory assessment for the automotive trade. All theory assessments were required to be undertaken as closed book, although amongst the lecturers the merits of the system were widely debated. However, the ITO defined that all theory, unless researching data relating to manufacturers specifications, had to be assessed as closed book.

Lecturer H: "Closed book and open book covers summative assessment—doesn't work well-more time is involved for students to search information. All summative should be closed (theory). Theory tests to relate to practical assessment to know exactly what is required, and integrated assessment would be a preferred option to use. Re-sit questions relate to performance criteria and should be at least $70 \%$ to pass. Students demonstrate ability to achieve practical and MIT determine presentation of assessment."

One refrigeration/air-conditioning lecturer felt that the way that assessment was delivered required some review and suggested as an alternative consideration to have "trade tests" (previous trade certificate practical tests) re-introduced and assessment related to achievement as a preferred method. 
Lecturer B: "Assessment is flawed! If someone fails an assessment, it must be equitable and fair. Tell them the truth that they have failed and that they need to know how to put it right. Students must reach required standards (no fudging). Better to have trade tests and exams and to return to achievement based and exam system for years 1,2 and $3 . "$

Statements made here suggest that current assessment processes may not identify competency standards, and if students fail to reach the required levels they may not be advised of their capabilities. Alternative measures suggested were a return to trade tests through an achievement based examination system. However, that was an unlikely scenario as all assessments were controlled through the New Zealand Qualifications Authority, and any changes to existing assessment systems required major reform.

It was agreed that for some refrigeration/air-conditioning/electrical apprentices at the workplace, there was a lack of training on-job. Assessments should be arranged so that lecturers are engaged to carry out all of the assessments as on-job assessors. Alternatively, approved and trained assessors should be appointed to do so.

Lecturer E: "Must be independently done-so as an approved assessor may sign off as otherwise a conflict of interest may be deemed to occur. It would be better if MIT was to carry out all assessment combining off-job and on-job."

Currently, the process of assessment is carried out by employers or their staff where the possibility of invalid assessment is probable due to conflicts of interest.

\subsubsection{Communication}

Important aspects of the training programs were highlighted by the lecturers in terms of students gaining acceptable communication skills.

Lecturer D: "With the communication skills gained through team learning and team building exercises the students found that learning was very interesting."

Lecturer F: "Where students are in a class group they can gain further experience by discussing in a class group situation. When students are studying on block courses, they can share experiences together coming from different workplaces. Communicating together in class groups quizzing and team learning and building projects makes their learning more interesting."

This was partly achieved through the types of learning processes undertaken where students were required to work in group situations, particularly when they were 
required to engage in practical and project based learning curriculum. Apprentices from different backgrounds and workplaces enjoyed sharing their experiences and learning from each other in group situations.

A difficult and frustrating issue included balancing the levels of learning within the groups. This proved to be frustrating and challenging for the lecturing staff due to deficient school level education. This had an ongoing effect on learning at tertiary level with the belief by potential students that learning a trade was a manual occupation.

\subsubsection{Work experience and on-job training}

Work experience was perceived as an important component of the automotive and refrigeration/air-conditioning/electrical pre-apprentice training programs. For the students who attended work experience, the lecturing staff appreciated that on their return to the Institute, pre-apprentices were keen to espouse what they had learnt and to share their experiences with their peers. Although it was acknowledged that some workplaces were not recommended by the lecturers to be used for work experience.

Lecturer G: "At some workplaces the students can be taken advantage off and get told to do the wrong things, and in my opinion certain workshops would not be recommended as places to gain workshop practice."

Lecturers believed that in these workplaces the students could be taken advantage of and end up doing the wrong activities in terms of work practice. Instead of carrying out legitimate work, pre-apprentices could find that some of the work requested was inappropriate and not conducive to learning trade practices. For instance, as there was no guide given to the students about the nature of work experience, some of the students in the automotive pre-apprentice group were required to do menial tasks and they did not engage in suitable work.

A number of comments were made by the lecturers concerning the on-job work experience by some automotive apprentices and apprenticeship training at the workplace. The comments alluded to the quality and amount of training that was occurring there. 
Lecturer H: "Yes—students not gaining enough training on the job."

"No appropriate training at the workplace. All the possible current training that is available is only 10 weeks out of 3 years apprenticeship. However what we produce at MIT is as good but we need to step up too new technologies for the future particularly in the area of transport."

The lecturers were under the impression that not all training and assessment that was alleged to occur in industry met the requirements for an apprentice or for the on-job work experience component of their training plan.

Lecturer F: "Specialised equipment and tools not available sometimes at the workplace. Go forward with student program — with distance learning being indepth. Discuss distance learning packages at the block course with Lecturer and peers."

Concerns were evident that tools and equipment were a significant issue for a number of workplaces. For the refrigeration/air-conditioning/electrical apprentices attending block courses also provided opportunities for discussion pertaining to their distance learning assignments.

There were a number of pre-apprentice students who declined to engage in work experience due to a variety of reasons, particularly related to family and other personal commitments.

Lecturer C: "Lots of students have to work to support their families and have no time to work in the industry, however approx. $60 \%$ are placed in the industry."

Difficulties were apparent when older students in particular were studying to gain a trade qualification, but at the same time were required to continually support their families.

\subsubsection{Attitude}

For a few lecturers, the lack of discipline of a number of students was an issue, for instance, lateness to classes and failing to complete self-directed learning assignments. In addition, a few automotive students were showing a general lack of commitment, not meeting the course requirements and falling behind with their studies. 
Lecturer C: "Some start a bit late to class sessions, lack a little discipline, however they realised this previously, and know that it is important to be on time. Assignments and homework is not completed by specified times due to lack of commitment, and they do not meet course requirements. When students are not fully equipped with safety equipment for the practical sessions they cannot continue to do the work."

These issues were exemplified when students attended their work experience placements and of course such occurrences were not tolerated by employers. As a consequence, students acting in this manner were not able to complete work experience hours. According to the lecturers this sort of problem creates issues for other pre-apprentices who attend work experience, as the employers have experienced unsuitable students and may discontinue their involvement in training. Therefore, is it critical for lecturing staff to take remedial action and ensure that employers are on board, and to understand situations where this issue may occur so they can be part of the solution to the problem and deal with it appropriately.

\subsubsection{Industry Training Organisation support}

General frustration was emphasised with regards to the Industry Training Organisations (ITOs), where courses had been reduced in timeframes due to cost saving initiatives. This situation was a result of funding for apprenticeship training from the New Zealand Government not being increased. As a consequence, students had to complete their off-job practical course work and assessments in a lesser timeframe.

Lecturer B: "Yes-Students not gaining enough training on and off the job. The ITO needs to increase the course length for apprentices. Although full time courses would be more beneficial and the standard of engineering would rise. Three days' workplace and three days off- job would allow for more practical skills to be achieved."

There was no reduction of course requirements and the workload remained the same as for previous courses. Comments from lecturers indicated that there were some concerns pertaining to the support and involvement by the relevant ITOs, and suggested possible remedies to aid in the improvement of the ITOs' engagement in training methods. 
Lecturer E: "Incompetent ITO! Course materials badly written and the ITO not meeting requirements for course materials. There is also a lack of money, equipment and resources."

Through insufficient funds available for funding, lecturers argued that the ITO had some way to go to reach higher standards in terms of course materials and resources.

\subsubsection{Other matters}

Staff indicated that specialised equipment and tools were not available for a number of students at the workplace, and the only way for students to gain access and understand the application of the tools was through attending training programs at ITPs.

Additional improvements suggested were to return courses to an achievable length; however, the preferred option was for all students to enrol in a pre-apprentice program.

Lecturer A: "Students to attend pre-apprentice courses prior to getting employed in a job as this would allow students better opportunity of seeking employment."

"Full time programs or get real! On job training needs to be independently verified."

A possible alternative would be to provide an agreement where students could be employed and at the same time attend off-job training on a two-day workplace and three-day institute roster. Lecturers suggested that this method of training delivery would be more useful for students to gain improved practical skills.

There were also suggestions that secondary schools could be more involved in the delivery of tertiary training for students prior to commencing work at the workplace.

Lecturer F: "Better relationships and model for schools engaged into partnership programs and learning institutions."

Lecturers suggested that if secondary schools and tertiary providers developed enhanced programs of study in partnership, students would have a direct progression into pre-apprentice programs as the procedure for gaining relevant trade training.

Lecturers identified that the rate of changes occurring within the automotive trades industry was extremely rapid, and there was a necessity to embrace and adapt, particularly in training and education. 
Lecturer C: "Automotive is the fastest changing industry and we need to keep pace with change. We have to be strong to leave yesteryear behind. For example, engine rebuilding is something from the past. More on vehicle testing is required rather than repairs. Electronics need to be more plentiful. The result of the tertiary review process relating to course subjects will change things and allow more flexibility and we must look at progression. If unit standards remain under the new system the units will define the learning and allow achievability of the assessments and determine exactly what needs to be achieved."

Lecturer D: "To advance in the automotive trade there is a sound platform to build on for the future not only for NZQA but qualifications for industry. There is a need to build on generic skills and gain national qualifications later. Holistic learning processes and students capable of achieving and gaining satisfaction are crucial."

The messages delivered here were that technology within the engineering and particularly automotive industries are developing and changing to an extreme degree. As a consequence, there is a requirement to provide considerable changes to methods of training. Suggestions for ways to achieve the changes are to address graduate profiles and adapt learning processes to achieve outcomes.

\subsection{Findings from the Interviews with Employers}

The employers were approached by the researcher and invited to engage in the research as they were part of the industry engagement strategy with the lecturers and the corresponding ITP. All the employers approached operate small to medium size businesses and employ approximately 3-50 staff who are involved with pre-apprentice work experience or who employ apprentices (see Table 4.11). Some employers employed apprentices who had attended pre-apprenticeship training before commencing their apprenticeships and some did not. Due to their experience with either pre-apprentice and apprentices or both, the employers were in a suitable position to provide relative data regarding their professional opinions.

Data was gathered from the employers using semi-structured interviews which took place at their offices. The interviews were designed to elicit information and to capture and identify themes regarding the pre-apprentice and apprentices groups that were either employed or carrying out work experience with employers at the workplace. Key points were identified relating to the questions asked to gain an understanding from the employers' perspectives in regard to learning and assessment issues. The interview questions are in Appendix G. 
Table 4.11: Employers

\begin{tabular}{|c|c|c|}
\hline Course name & $\begin{array}{l}\text { Employers: Selected as partners for on-job and } \\
\text { work options }\end{array}$ & Employer code \\
\hline $\begin{array}{l}\text { Case Study } 1 \\
\text { Pre-apprentice students: } \\
\text { Refrigeration/air- } \\
\text { conditioning/electrical } \\
\text { Year } 1 \text { (6 months } \\
\text { completed) }\end{array}$ & $\begin{array}{l}\text { Two employers interviewed from local } \\
\text { refrigeration and air-conditioning/electrical } \\
\text { small to medium sized companies. These } \\
\text { employers are involved with work experience } \\
\text { for the pre-apprentice students on full-time } \\
\text { programs. }\end{array}$ & $\begin{array}{l}\text { Employer A } \\
\text { Employer B }\end{array}$ \\
\hline $\begin{array}{l}\text { Case Study } 2 \\
\text { Pre-apprentice students: } \\
\text { Automotive } \\
\text { Year } 1 \text { ( } 8 \text { months } \\
\text { completed) }\end{array}$ & $\begin{array}{l}\text { Two employers interviewed from automotive } \\
\text { franchise dealerships in South Auckland. Both } \\
\text { employers are involved with work experience } \\
\text { and currently have pre-apprentices at their } \\
\text { workplaces. }\end{array}$ & $\begin{array}{l}\text { Employer C } \\
\text { Employer D }\end{array}$ \\
\hline $\begin{array}{l}\text { Case Study } 3 \\
\text { Apprentice students: } \\
\text { Refrigeration/air- } \\
\text { conditioning } \\
\text { Level } 3 \text { (Year 2) }\end{array}$ & $\begin{array}{l}\text { Two employers interviewed from local } \\
\text { refrigeration and air-conditioning/electrical } \\
\text { small to medium sized companies. These } \\
\text { employers were involved with work experience } \\
\text { and had employed students as apprentices } \\
\text { previously. They both currently have } \\
\text { apprentices employed at their workplaces. }\end{array}$ & $\begin{array}{l}\text { Employer E } \\
\text { Employer F }\end{array}$ \\
\hline $\begin{array}{l}\text { Case Study } 4 \\
\text { Apprentice students: } \\
\text { Automotive } \\
\text { Level } 3 \text { (Year 2) }\end{array}$ & $\begin{array}{l}\text { Two employers interviewed from small } \\
\text { automotive repair workshops in South } \\
\text { Auckland. Both employers had previously } \\
\text { employed apprentices. }\end{array}$ & $\begin{array}{l}\text { Employer G } \\
\text { Employer H }\end{array}$ \\
\hline
\end{tabular}

Total: 8 employers

\subsubsection{Themes from employers}

\subsubsection{Training apprentices}

Employers from both disciplines indicated that it was important for the industry to train apprentices, and some of the most satisfying desires were to be able to train apprentices the way that industry wanted to train them. They stated that when apprentices stay with employers for the long term, training becomes a worthwhile enterprise. Employers were appreciative of students who have the correct attitude towards employment. Five employers said that it was difficult at times to attract suitable applicants to work as apprentices. 


\subsubsection{Communication skills}

When bearing in mind the on-job training question, some employers from the automotive industry advocated that good training was occurring at the workplace and apprentices and pre-apprentices were gaining good communication skills. Interacting with customers at the workplace was understood as an important function for apprentices and students on work experience, and it was important that they gained interactive and communication skills to be able to do so well. Employers from the refrigeration/air-conditioning/electrical field stated it was valuable to pass on knowledge to students and apprentices at the workplace to enable them to gain real skills. When students were placed with technicians to work on tasks they gained hands-on on-job experience not only with the technical aspects of the work, but also when the technicians interacted with customers to discuss work requirements and customer expectations.

\subsubsection{Attitude}

Employers thought it was extremely important for pre-apprentices and apprentices to have the correct attitude towards employment when they were looking for work, when attending work experience and when carrying out work practices.

Employer E: "It is good when students have the correct attitude towards the employment. Sometimes can be difficult to attract the right apprentice that is suited to my workplace as they need to fit in."

Employers indicated that when pre-apprentices take on work experience opportunities it was necessary for them to demonstrate the correct attitude towards a particular trade. Equally important was for pre-apprentices to portray that they are prepared to learn and listen to instructions when carrying out various work tasks. It was also necessary to understand the requirements of the workplace and how to act in a suitable manner. Employers stated that when pre-apprentices are actively engaged in work experience and fulfil their tasks, the majority will eventually obtain employment as a result. Comments were made that attracting and finding a suitable apprentice for the job can be difficult. 
Employer C: "Learn soft skills and attitudes and behave differently in industry as students need to know correct work ethic."

An important issue noted by an automotive employer was that when students make a decision to enter a specific trade they need to ensure it would be suited to them, otherwise entering into the wrong trade could prove problematic not only for the students but also for the employers. The employers mentioned that when employing apprentices, those that had completed a pre-apprentice program had a better idea about what they would be doing when employed.

Employer D: "Students that have completed a pre-apprenticeship program have a clearer view about what working at the workplace is about, as they have covered some of the basic skills during their courses and have an understanding of the trade.

It was considered that apprentices with some base knowledge gained through a preapprentice program were more likely to continue with their apprenticeship compared to new apprentices who had not completed a pre-apprentice program, and had no prior training before working in a trade.

Employer H: "As an automotive employer for over 30 years I have had a number of apprentices; had some that have just walked in off the street and have succeeded. However dependent on their background i.e. mechanical or nonmechanical they have to work harder at it in comparison to ones that have attended pre-apprenticeship training, yes that (as I said earlier) initial edge is taken off".

The majority of employers stressed that for pre-apprentices accepting an apprenticeship, there were definite advantages to attending a prior pre-apprentice program. Training as a pre-apprentice would have enabled a range of fundamental knowledge and skills conducive to succeeding as an apprentice.

\subsubsection{Training systems}

Another satisfying theme that emerged for employers was that it was useful for preapprentices to go to the workplace with some fundamental knowledge. This allows the students to be able to understand, for instance, how the industry operates, how vehicles operate, and basic training in health and safety requirements. 
Employer C: "By knowing that industry has trained the apprentices and that you are able to train the way that you want to train the apprentice. Also when the apprentice fits in and stays with your company for the long term."

Employer D: "Time for an employer is money, and one satisfying thing is that from the pre-apprenticeship course is that the student comes with some knowledge of the industry. However it does take a few years before apprentices turn profit, but by attending pre-apprentice training it takes the edge off for an employer's commitment to the apprentice."

It was also seen as worthwhile when apprentices stayed with the companies for the long term after training, as employers have made a considerable investment. When apprentices showed commitment and were loyal to the companies, then employers and employees both benefited.

Employer H: "Enjoying seeing apprentices when the light switch comes on and when they get it! To be able to pass on knowledge to students and apprentices. Also by enjoying having my own workshop and interacting with customers."

Employer E: "Block course are worthwhile as we can see before and after, what they were like before going to the block course and what they are able to achieve after completing the course."

Employers gained considerable satisfaction from employing apprentices. Not only do the apprentices gain significant knowledge and skills from off-job and on-job training, but the employers are able to contribute to the apprentices in terms of experience and specific trade expertise. Automotive employers indicated that once apprentices have basic skills then it was up to employers to train them with the skills necessary to suit their particular vehicle franchise and to technician level.

Employer D: "Visits to workshops including peer learning. Brakes technologies not covered and increase on-job learning from the institute. More e-learning, more computers and resources for computing on courses."

Basic training at the Institute leading to troubleshooting techniques and diagnostic skills required more attention when apprentices were released for training. It was suggested by employers that training courses should include tuition in additional advanced studies to ensure currency with industry practice. 
Employer C: "Concerns are that the automotive industry is ever evolving, i.e. technologies are changing in repairs, test equipment is now required to be able to diagnose and repairs have changed considerably in the last 15-20 years. A modern workshop spends considerable amounts in keeping up with those trends, so for pre-apprentices have to spend a lot of time to catch up if they haven't had experience with the technology."

There were suggestions that the curriculum required updating to meet the ongoing changes in industry. It was absolutely critical that pre-apprentices had exposure to new technologies, otherwise to keep up with current requirements in the workplace would be challenging.

One employer commented that a graduate who had been employed by him in the past had been unsuccessful in meeting required standards. A few employers had suffered unfortunate experiences as a consequence of employing pre-apprentices below standards as apprentices. They found that some apprentices would get distracted when away from the workplace at training courses and did not concentrate on their learning.

Employer F: "Very difficult at times getting the right student to start as an apprentice. Not all students will succeed as it takes commitment and drive. It has to come from the kids, as they have to want to do it. For those that do achieve it is both beneficial to the student and for the employer as the employer will take them on and employ them. Good employers will invest in their staff and will help them."

Employers said they would employ pre-apprentices who showed commitment and who had the ability to succeed. They believed the emphasis must be on the preapprentice to prove that they really want to work in the trade and to show a passion to achieve.

Employer A: "Better assessment of what part of the industry they may wish to enter into, then they can have further training in certain areas in that direction. They need a good understanding of the basics adhered to."

Employers said that they will invest in the students and give them the opportunity to complete an apprenticeship if they are convinced the students really want to move ahead with their career.

However, for some employers in the refrigeration/air-conditioning and electrical industry, there was difficulty and frustration in understanding how the training system for apprentices was supposed to work. Some employers in the refrigeration/air- 
conditioning/electrical field also found keeping track of apprentices' training plans with the ITOs difficult at times, and understanding previous units and assessments that had been completed were not always clear.

Employer B: "Training is not required at the Tech as students need to acquire life skills and develop the correct attitudes and this can be done at the workplace.

Students get distracted away from the workplace. They are here but not here!"

A few employers were not convinced that all training was required to occur at the Institute. In terms of life skills and attitudes, they believed these skills were better placed to be taught at the workplace. There was also uncertainty for some employers concerning further training options for pre-apprentice students, as they have the option to gain employment directly as employees and train at the workplace.

\subsubsection{Work experience and on-job training}

A number of employers found it encouraging that pre-apprentices could become an asset after they were able to train them in a practical way at the workplace. One refrigeration/air-conditioning/electrical employer indicated that it was beneficial for apprentices to go direct to the workplace, prior to carrying out any training. Once preapprentices were ideally first placed into the field and established in work mode, the off-job training could occur later.

Employer A: "I feel that students should not go to the institute prior to going into the workplace. Students should be put into the field first. Have had a bad experience with some students locally and have taken on people from overseas who are better to employ."

One employer indicated that it was through this method that initial training relating to the workplace could be completed, and perhaps after an agreed time period, the apprenticeship training could commence with off-job training courses.

Conversely, five employers reflected that the pre-apprentice programs were working well and were considered valuable. 
Employer H: "The pre-apprenticeship program takes 1 year to complete and that reduces the time required as an apprentice at the workplace and saves in time and money."

Considerable benefits were acknowledged by the five employers that included reduced training of one year or more with an apprenticeship, which in turn saves costs for the employer.

Other advantages that worked for both the employers and students were improved connections between industries and off-job training courses. Industry experience was quoted as being essential and worthwhile for students to have undertaken prior to being employed and necessary to be included in the programs.

Employer E: "Yes! Industry on-job training leads to apprenticeships and is encouraged."

Employer H: "Yes particularly where more expensive equipment is involved, i.e. wheel aligners, brake lathes, scanners etc. It works or has for me! (I will use the term if you treat it like your own because if you break it you will!). I have had good experiences with on-job training, and how you see the apprentice develop into a tradesman. Many apprentices like the practical side, but staying with the company is another issue."

Benefits from attending the training courses were cited as apprentices gaining a full understanding of their trade and receiving full training towards their theory and practical requirements to meet the needs of the workplace. Students who had completed pre-apprentice courses were also better off in terms of meeting work requirements, and a majority of graduates were able to gain employment not only in the direct industry but in related work.

Employer A: "The course is good and is a good grounding for employment and for being employed as an apprentice."

Employers were of the opinion that the current training programs met the requirements of industry and that the courses gave a good grounding for employment and for being employed as an apprentice. In these workplaces, trained technicians would take on the apprentices and assist them with their training plans to ensure they were meeting the requirements of achieving the on-job work and assessments. 
Employer E: "MIT is where good pre-apprentice training takes place and employers send students to MIT to gain their certificates."

Employer D: "There are some issues at the workplace for pre-apprentices but by discussing with others there they are able to upskill talking amongst themselves. We buddy up the students with tradesmen and carry out a mentoring process."

One employer from the automotive trade indicated that when new pre-apprentices attended work experience it was sometime difficult for them to adapt to the workplace culture. However, by selecting a tradesman to look after the pre-apprentice they are able to fit in and feel part of the work environment. The majority view from employers was that the pre-apprentice programs were worthwhile and they believed that students gained far more in-depth knowledge and practical skills, and achieved further confidence in preparation for attendance at the workplace. The employers noted some of the following benefits for students attending the courses:

Employer E: "Students gain a full understanding of the trade covering practical and theory subjects. For a large majority of students completing the program leads to employment. Oher students may gain work in electrical fields and related areas."

Employer G: "The students are capable of having a good understanding as to how cars and trucks work and are able to work on vehicles at the workplace during and after the program. As a result they are able to work with limited supervision in the workplace."

Employer H: "The benefits for students attending the course are that they get a good look at the variety in which the industry has available, and in turn they will get an idea in what direction they may choose to go in."

The majority of employers believed that a significant benefit for pre-apprentice students was the opportunities that could lead to full employment as apprentices. Employers believed that once pre-apprentices were engaged in workplaces, they had a greater understanding of work requirements and were able to work with limited supervision. On completion of the programs, students were able to make informed decisions for their future direction in specific trades.

\subsubsection{Practical learning activities}

All respondents indicated that the practical hands-on work at the workplace was a key component for students to gain practical capabilities in undertaking real work.

Industry experience was quoted as being important and worthwhile for students to 
have, prior to being employed and it was necessary to be included in the programs. Industry on-job training leads to apprenticeships and should be encouraged.

Employer D: "Yes_-far more in-depth knowledge and practical skills, students gain more confidence. As a tradesman seeing practical and seeing that theory is demonstrated. Theory is delivered as integrated practical training and works on the job. Enjoy training the students particularly in a practical way as they gain a good understanding of what goes on in a vehicle."

Comments relating to training were very positive and the majority of employers enjoyed training the pre-apprentice students at the workplace. Researching data such as manufacturer specifications was an example of an important requirement at the workplace for apprentices to be capable of. Additional practical training was seen as being critical, as well as an emphasis on how theory relates to the real world. This allows the theory learning off-job to be integrated to the practical requirements on-job.

Employer D: "Nothing wrong with the program as it is, it works well and have taken on a number of pre-apprentices. Works for students and they ask lots of questions for the level 3 and giving students industry experience. At the workplace the theory is taught in a practical way within a workshop environment if possible for students to understand topics."

Lack of practical, hands-on training also featured in employers' comments relating to pre-apprentice training. Some said that training should be less about theory and more about the practical and how things worked. More practical training, and an emphasis on how theory relates to the real world of work, was needed. Improved practical training courses should integrate the theory components to illustrate that the theory has been learnt and can be demonstrated in a more efficient way.

Employer G: "I would like to see an improved connection between industry training and other training arrangements. Further training could include: first aid, fork truck licence, site safe, car licence/HT licence and welding."

Employer F: "Not enough practical learning! It is a practical based trade and can be repetitive but becomes second nature. Too much theory and some content is not required and doesn't need to be there. There is too much emphasis on theory topics and the training must be relevant."

Initial training needs to be skill based for pre-apprentices, and they need to be taught more practical work skills; for instance, how to use hand tools and knowledge about fundamentals. By doing this employers would be able to use these skills at the 
workplace and more knowledge based theory could be brought into the curriculum at a later time.

Employer E: "More practical training is necessary and an emphasis on how the theory relates to the practical at the workplace."

Employer C: "Before taking on a pre-apprentice student I would ask them if they have done services apart from just doing their practical units as they are very confined. Industry moves very fast and for the students the gaps are too huge to step across. There is a need for the apprentices to gain a good grounding in mechanical and electrical technology, as there is a need for collective technology information. Need time to take stuff apart and induce faults and determine how to repair and understand how things work."

Further practical activities were seen as important, including: work experience; increased on-job learning from institutes in conjunction with workplaces; visits to industry workshops by pre-apprentices prior to going into industry; peer learning at workshops; and understanding specialised skills, i.e., vehicle brake technologies and heavy vehicle work. Employers also mentioned some difficulties in terms of employing apprentices as there is a financial cost and apprentices can be a liability as damages can occur at the workplace.

\subsubsection{Assessment}

Employers are required to carry out on-job assessment tasks that meet the requirements of the New Zealand National Certificates. The on-job assessment tasks have been determined by the ITOs for the different trades in the engineering field. The workplace assessments can only be carried out by accredited supervisors, ITO assessors or approved on-job assessors. Employers indicated that they were generally happy with the way that assessment currently works and they have their own protocols around certain tasks at the workplace.

Employer B: "Industry uses their protocols around assessment. We have set tasks to do and work in with the institute regarding assessment i.e. block course training."

Employers believed that they work well with institutes and that they have their set tasks that they can do. They stated that when carrying out assessment nothing goes unnoticed. Commercial aspects have to be considered when dealing with assessment 
tasks, for instance, when completing customer work there are not always feasible assessments to carry out due to the type of work required.

Employer E: "Happy with assessment as it is! The assessment units are written by industry personnel for delivery at the institute and at the workplace and they meet the criteria, and are moderated by the ITO. Assessment is on-going, works well, at a high standard and is covered by element."

Employers advised that the assessment criteria is owned and written by industry personnel for delivery at institutes in conjunction with the ITOs. It has to meet the requirement of industry and they believed that current assessments work well, ensuring that high standards are met for all concerned.

Employer D: "Personally I have always believed, that to work in the automotive industry one has to have an inclination towards the job, and the repetitive nature of the job is usually (for me) an assessment tool. From a practical point of view and from a theory perspective, what appears to be delivered is in line with current industry trends."

The point being made here is that at the workplace, the repetitive nature of a number of jobs required on an ongoing basis is actually an assessment tool. Industry sets the required assessment tasks by the very nature of the work conducted on-job within the workplace.

Employer C: "With assessment it is practical and task related and if there is a job that cannot be assessed then we contact another dealership if we have a guy that needs assessing as there are wide industry contacts. However it's not easy for small corner garages as they don't have particular work to assess on, I feel a small percentage of industry lets the side down with assessment."

Assessment of apprentices is continually carried out in the workplace. If an employer is unable to complete an on-job assessment they can arrange other assessment tasks that meet the criteria - this was particularly the case for franchise dealers who were able to work with other dealerships. However, for the smaller companies, arranging assessment tasks can be more difficult as commercial factors always have to be considered to ensure the job is completed.

Some employers considered that some of the ITO assessment material was "over the top" and that some questions and tasks required some modification to meet the required learning outcomes. 
Employer B: "The assessment works well, however some assessment questions require modification and some of the ITO material is over the top."

Employer A: "For competency based assessment it works well with project based work and assessment carried out on finished task."

Employer H: "Theory — some questions are over questioning, some don't cover the PCs and should be more relevant. Having better resources to work on, more use of scopes and scan tools and additional technology in courses."

Project based assessment for the refrigeration/air-conditioning/electrical apprentices at block courses was considered to be an effective method of ensuring that when the project was completed, the overall assessment was based on the final outcome of the project work.

\subsubsection{Communication skills}

It was alluded to in the comments from the interviews that the Institute could also be involved in providing a better service in training students in life skills, employment interview techniques and writing references for students to gain employment. A higher level of basic skills was also seen as an important issue where, for instance, reading and writing and good numeracy levels were a necessity to work in engineering industries, where problem solving is a key requirement.

Employer C: "The academic level of students is too low going into preapprenticeship courses, the technology is over their heads and we lose them. We need to produce technicians that can work on high tech cars dealing with electronics."

Nonetheless, issues occurred when students were enrolled into institutes as there were no entry criteria. The only stipulation was a requirement for the applicant to achieve the practical component; otherwise, most of the pre-apprentice programs were an open entry policy which was a concern to a number of employers. For employers, it was essential for pre-apprentices to have a high level understanding of technology.

Employers believed that more could be done by the institutes in terms of industry support and engagement, and possible partnership arrangements to assist the institutes with equipment and resources. Four employers felt that sometimes it can be difficult to attract the right apprentice for their workplace and there needs to be improved mechanisms for selecting applicants. 
Employer E: "Student services could improve support for CVs for students, interview techniques, writing reference for employment. Improved industry support and industry engagement from MIT."

There was mention of additional tuition being needed in "soft" skills such as timekeeping, body language, character and attitudes.

Employer B: "Would like better communication, consultation or customer focus from ITOs and more students engaged on work experience."

Some comments related to a particular aspect of service, while others were general requests for improved communication and people skills.

\subsubsection{Attitudes}

One employer expressed some unfortunate experiences and concerns with some preapprentices' attitudes, timekeeping, communication skills and general work ethics. Most employers key points emphasised correct attitudes and work skills, and stated that if these attributes were in place working in industry would be far easier for apprentices.

Employer F: "Good time keeping is essential for students to be skilled at, and body language for instance showing that they wanted to work, and the correct character for the job. Teaching is not as important, their attitude is! We need fundamentals and basics for trouble shooting. Better screenings of students' intake to ensure trainees are aware of their chosen career."

Employers believed that it was important for students to acquire life skills, soft skills and to develop the correct attitudes towards work and learning and know how to behave at the workplace.

Employer A: "The most important skills are correct attitude and work ethics; once these are put in place they will soon learn other skills."

Employer H: "The attributes that are required for the students are good levels of basic skills including literacy and numeracy and the ability to learn how to problem solve." 
Employer C: "I am always wary of pre-apprentices, and not sure if I would take them on particularly at the outset. However, in a franchise we can throw all our resources at them. When looking at work experience I am always profiling, checking them out, and looking for enthusiasm and the correct attitude. I would only offer employment to a few as if they haven't got the basic attributes and the correct work ethic then not interested."

According to the employers, a selection of students appeared to have mixed commitments towards their learning and work involvement. Enhanced screening was noted as an improved strategy for accepting students into programs and courses. If this was in place, then pre-apprentices would have an improved awareness of their chosen career path. Comments indicated that there was a need to improve the attitudes that students came to the workplace with.

\subsubsection{Other issues}

Equipment and resources were emphasised as an issue by a few employers, as well as the institutes not having enough correct and up-to-date equipment, including specialty equipment to be able to carry out the course requirements and assessments.

Employer E: "More up to date equipment at the institutes needed to meet the technology requirements and further practical equipment. Maybe need to partner with companies to assist with equipment to achieve the practical tasks."

Employer D: "Not having the correct gear — enough equipment and specialty equipment. Tools etc. need replacing and is expensive to do."

The institutes were seen as limited in being able to meet the technology requirements. Partnering with companies to build up resources was suggested as a way forward and a number of equipment items were highlighted that requiring updating.

Some employers felt that pre-apprentice programs provided students with unrealistic opinions on their abilities. A number of graduates had limited experience at the workplace and some pre-apprentices taking on an apprenticeship were not quite as ready as the employers thought they were. 
Employer G: "A student or pre-apprentice can come to you with some basic skills, which once assessed; can give you as an employer an idea as to what their capabilities are."

Employer H: "The question needs to be asked of the students; have they previously carried out vehicle services? The units that they have achieved are very refined and industry moves too fast and the gaps are huge for them to step up to meet the requirements. The training is just adequate at the institute and needs to be what industry requires."

Basic training was identified as an important prerequisite for students, particularly when considering moving into an apprenticeship position, for instance, training in industry tasks that would be relevant when commencing an apprenticeship.

As part of the training agreement for employers and apprentices, the ITOs are required to ensure that the apprentices are meeting their training requirements on time and on schedule. In doing so, the ITOs must make at least three visits per year with the apprentices as part of the agreement. Employers advised that the visits and contact from the ITO industry managers were there to support and administer apprentices in the workplace. Improved monitoring of apprentice progress, as well as reporting progress back to the employers, was identified as an issue that required remedying.

Employer D: "Paperwork through MITO is too substantial and there is difficulty in understanding how the system is supposed to work which can be frustrating. Some difficulties with students understanding what previous units had been completed. Some resource issues trying to achieve some units as they are not available at the workplace.”

Improved communication between industry and ITOs and from ITOs in general, was suggested as an area with room for improvement.

There were also concerns relating to the quality and usefulness of the Motor Industry Training Organisation (MITO) as it was stated the motor industry had moved on but the MITO had not. The employers felt that the other engineering ITOs were doing a reasonable job with their apprentices. 
Employer D: "MITO is quite a dinosaur! Industry has changed but MITO hasn't changed, they are still giving the same message as they did in the 1990s. They need to move forward in terms of time, the landscape has changed and they are not connected with industry. They need to look carefully at what needs to be assessed at the workplace."

In terms of effectiveness, employers believed that the MITO had fallen behind with the latest industry technologies and the assessment requirements had changed. They saw a need for industry to conduct a review to identify current industry practices and conditions.

Employers mentioned that there was a lack of funding through the ITO for training costs, particularly when apprentices were required to be away on training courses at the institutes for off-job training.

Employer C: "It is difficult having apprentices as there is a cost to it and apprentices can be a liability as damages can occur."

Overall, apprentices were considered to be an asset to a company; however, at times they were also seen as a liability when situations arise, for instance, when damage to plant or equipment occurs due to unfortunate incidents through inexperience. There is also a requirement for off-job training that comes with a cost to the employer.

\subsection{Chapter Summary}

This section summarises the experiences, perceptions and opinions of all the participants that were presented in detail. Key points are highlighted, relating to the benefits and challenges associated with the different modes of learning for the two identified trade occupations in New Zealand and for the two specific learner groups within the study (pre-apprentices and apprentices).

\subsubsection{Summary of findings about pre-apprentices}

The following data relates to the pre-apprentices from all the participant groups.

\subsubsection{Knowledge and skills gained}

Overall, the comments regarding the benefits of the pre-apprentice program for the refrigeration/air-conditioning/electrical and automotive engineering students were 
very positive. The comments indicated that the programs provided a substantial knowledge and skill base in preparation for the workplace. Confidence was also seen to be boosted by what the students learned about how to search out an apprenticeship position in industry. Students found that being a pre-apprentice provided an opportunity to meet others and to gain some insight into what apprentices were doing. They noted what the requirements were at the workplace and how their learning plan matched. It was noted that through achieving success with their pre-apprentice program, the time to complete an apprenticeship was reduced.

Industry experience was quoted as being important and worthwhile for students to have prior to being employed. Industry experience was strongly advocated as a necessary inclusion in the pre-apprentice programs as a compulsory portion of the curriculum. The data confirmed that employers found it encouraging that students could become an asset after they were able to train them in a practical way to suit their workplace.

Attributes that were considered as important by the students, lecturers and employers included soft skills and tuition on timekeeping, body language, character and attitudes were identified as being important. Once students had achieved these skills their ability to secure an apprenticeship was enhanced, and continue learning at the same time as working in a specific trade occupation.

\subsubsection{Assessment}

A number of comments from all the respondent groups indicated that the assessment process worked effectively and was appropriate. Students liked the way that assessment formatively checked how much they understood of the knowledge they had gained. Assessment tasks, particularly for the practical units, were indicated as helpful and re-assessment opportunities were described as reasonable. Integration of both theory and practical tasks were suggested as an improved option.

Lecturers from both cohorts could see advantages in improving the way that theory assessment was delivered by upgrading to digital online learning methods. Comments from the pre-apprentice automotive lecturing staff were that the current assessment process worked well, and that the methods used were complementary, particularly when pertaining to practical activities. 
The pre-apprentice lecturers in the refrigeration/air-conditioning/electrical cohort stated that they were satisfied that the project methodology utilised was efficient and reflected industry practice.

Respondents in the automotive pre-apprentice group indicated that the assessment process was appropriate, and the way that the formative assessment tasks checked understanding of the topics was useful. There were some issues, however, in terms of the theory assessment questions on some topics, and suggestions were made that certain question should be re-written.

Comments from employers indicated that assessment generally worked well at the workplace, as the assessment criteria was written by industry training organisations for both delivery off-job at an ITP and on-job at the workplace. Employers emphasised that for project based assignments, the assessment was integrated and was effective through to the finished project.

\subsubsection{Work experience}

The work experience component required students to find and arrange their own work placements. This proved difficult for many of the students across both the refrigeration/air-conditioning/electrical and automotive disciplines, and as a result the students spent considerable time trying to source a suitable workplace to attend. The overall responses given in the data indicated that the work experience should be a compulsory component of the program and should be arranged by the Institute and incorporated into the full-time program.

The lecturers agreed that an important component of the pre-apprentice full-time program was industry engagement for the students on work experience. Not only was the work experience component of benefit to the students, but it proved to be of significant value for the lecturers due to working with employers. When students were studying on pre-apprentice programs, they had the opportunity to attend work experience where the advantages were significant. For instance, employers were able to observe the students' abilities and aptitude at the workplace, and evaluate them for future employment once the students had graduated from their courses. 
Findings indicated that pre-apprentices found learning at the workplace to be invaluable as they learnt new skills from the technicians they were supervised by. Data suggested that the learning prior to the workplace experience proved extremely useful as once there, the students were confident in the use of special tools. The data showed that pre-apprentices were gaining respectable communication skills and learning computer software practices with a number of tasks. Technicians at the workplace would assist them with their training plans to help them to gain deeper knowledge and skills to achieve their unit standards. On-job training for preapprentices leads to apprenticeships and should be continued.

It was stated by employers that an on-job industry engagement plan for work experience needed to be developed by the Institute to provide an improved system for placing pre-apprentices into the workplace. It was also felt that the Institute could be involved in providing a better service in training students in life skills, employment interview techniques and writing references for student to gain apprenticeships.

\subsubsection{Work readiness}

Moving into the workplace from a pre-employment program allows pre-apprentices to go into the workplace with a solid knowledge base perspective to be immediately productive. Employers indicated that the students graduating from the preemployment program were requested for recruitment and employed straight into apprenticeships. A significant number of students who contributed to the findings had actually been in other types of employment prior to entering the program as preapprentices. This finding was encouraging as these students already had the skills needed for the workplace.

Benefits from attending the training courses were cited as students gaining a full understanding of their trade, and receiving full training towards their theory and practical requirements to meet the needs of the workplace. Generally, employers were of the opinion that the current training programs met the requirements of industry and that the courses gave new apprentices a good grounding for employment. 


\subsubsection{Gaining a job}

The data indicated that both automotive and refrigeration/air-conditioning/electrical pre-apprentices understood that completing their full-time program was a worthwhile experience, and that the knowledge gained was essential to continue on their career path as technicians. There was an essential need for them to learn diagnostic skills and techniques to be able to rectify problems when they are employed at the workplace. By attending a pre-apprentice program there was a greater chance of gaining a job on completion, as many industry employers were prepared to employ "pre-employment" students as their first option.

Students realised that for them "learning is time well spent and it was far better than doing nothing at all". Overall benefits included the opportunity to gain the "hands on practical work" and using tools not previously known about or used. Further benefits related to completing the theory units towards their national qualification, and not needing to undertake more theory once they were employed.

\subsubsection{Major differences between the pre-apprentice cohorts in the two trades}

This section highlights the major differences between the refrigeration/airconditioning/electrical and automotive trade pre-apprentice cohorts.

Refrigeration/air-conditioning/electrical:

- Time management of theory relative to practical activities and assessment tasks was not synchronised effectively.

- Project based learning opportunities, such as designing and assembling air conditioning units, were highlighted as worthwhile.

- Time reduction to complete an apprenticeship through attending a preapprentice program was indicated as a major benefit.

- Finding work experience was a major issue for the refrigeration/airconditioning/electrical groups.

- Four students in refrigeration/air-conditioning/electrical were already apprentices but were also studying as pre-apprentices. 
Automotive:

- By learning practical skills and using technical test equipment, the automotive students indicated that they were better prepared for future employment in the motor industry.

- Students in the automotive groups found working at the workplace extremely valuable.

- Practical assessment activities were noted as a positive experience for this group.

- Automotive pre-apprentices were actively approached for employment as apprentices at the conclusion of pre-apprentice programs.

\subsubsection{Summary of findings about apprentices}

The following data relates to the apprentices from all relevant groups of respondents.

\subsubsection{Knowledge and skills gained}

It was indicated that students who were directly employed as apprentices in the workplace lacked full training due to insufficient work being available in some workplaces. The off-job training option available was also insufficient as apprentices were only able to achieve a total of ten weeks' training out of a three-year apprenticeship.

Other difficult and frustrating issues about the apprentice training programs were also identified. For instance, some students would get distracted when away from the workplace at training courses. It was also a challenge for employers to find the most suitable person to take on an apprenticeship.

Some automotive employers found it sometimes difficult to carry out training due to a lack of specialty equipment and due to the cost of that equipment. Basic training, including in troubleshooting techniques and diagnostic skills, required more attention when delivering courses off-job. For block course training, industry students voiced a need for changes to be made to meet higher industry standards. 


\subsubsection{Assessment}

From the data collected, it appeared that there were significant difficulties for several apprentices in both disciplines to complete the on-job requirements of achieving unit standard assessments at the workplace. The apprentices indicated that the scope of work did not always cover the unit standards that were part of the training requirements to meet the national certificate. There were concerns that the training available at the workplace may be insufficient and subsequently this led to issues of completion. There were also concerns relating to the validity of assessment practices by some employers at the workplace due to incorrect assessment marking. These concerns were also confirmed through the data from the lecturers.

The lecturers teaching on the apprentice refrigeration/air-conditioning/electrical offjob cohort indicated that assessment within practical projects was particularly valuable, as it measured the students' ability to complete all components of the project. The final result of the assessment process was confirmed through observations of fully operational refrigeration working units. For automotive lecturers, issues with assessment included the timing of theory assessments in relationship to practical activities. Once practical assessments had been completed the apprentices would relate to the requirements of the theory topics more effectively and have a better understanding of the assessment questions.

The majority of employers indicated that they were happy with the way that assessment currently works and stated that they have their own protocols around certain tasks. They believed that they functioned well in their relationships with institutes. To ensure that assessment meets industry standards, employers specified that it must have also been pre- and post-moderated by ITOs. Finally, an issue for a number of apprentices in terms of their off-job training and assessment was a lack of assessors to assess their practical assessment tasks.

\subsubsection{Training support on-job}

Suggestions were made regarding the role of the ITO in the training program, and that further support was required in order for apprentices to gain their on- job credits. The ITO was not available to assist the training at the workplace due to the number of apprentices who required monitoring and assessing. A further suggestion reported that 
it would be beneficial for more experience to be gained at the workplace prior to an apprentice being signed up. Overall, there were a number of ideas stated as to how an apprenticeship might be improved, including some helpful suggestions as to how employers could make some changes to provide quality training at the workplace.

Data obtained from the apprentices regarding their training at the workplace gave a valuable indication as to how the training is actually perceived in reality. Comments indicated a mixed response showing some positive and satisfying aspects of training. A number of apprentices indicated that for them, working and attending block courses, and gaining on-job learning at the workplace, was preferred to studying on a full-time basis. Indeed, some of the apprentices had not studied as pre-apprentices and were not familiar with that style of learning.

The training required at the workplace was seen as a significant issue by the apprentices. Some students indicated that at times training did not occur due to a number of reasons, for instance, the workplace might become too busy and the technicians may not have sufficient time to ensure that training occurred on a regular basis. The training at the workplace was portrayed as needing to be more organised and synchronised with the off-job training program.

\subsubsection{Major differences between the apprentice cohorts in the two trades}

This section highlights the major differences between the refrigeration/airconditioning/electrical and the automotive trade apprentice cohorts.

Refrigeration/air-conditioning/electrical:

- Time allocated for their off-job training was insufficient.

- Key components of training in the workplace were identified as being issues, including the need for some employers to embrace training as an important function.

- High expectations for apprentices for completing certain tasks without adequate prior training.

- Disparity between students' levels of current training and knowledge when attending off-job training courses. 
- Lack of on-job assessment for a number of apprentices since commencement as an apprentice.

Automotive:

- Receiving pay increases when reaching different levels throughout their apprenticeship was seen as a bonus.

- Insufficient time for technicians to ensure that training occurred on a regular basis at the workplace.

- Issues concerning recognition of prior learning and cross crediting previous skills and knowledge prior to starting as an apprentice.

- Troubleshooting techniques and diagnostic skills training required for off-job training.

\subsubsection{Improvements suggested by participants}

This section identifies the themes provided by the data, and compares and contrasts the different views of the respondents. The pre-apprentices, apprentices, lecturers and employers suggested a range of improvements for future training programs and courses.

\subsubsection{Training curriculum}

The students suggested a number of improvements related to the training curriculum. For instance, in terms of time management of classes and practical workshops for preapprentices, time was stated as being too short, and increased practical sessions were suggested. When considering the delivery of theory and practical tasks, lecturers considered that combining theory with practical work through an integrated method would be the ideal way to proceed. However, employers suggested that additional practical hands-on skills were needed as these were lacking when students arrived at the workplace. There was also a demand by the students for increased practical training (including projects), and for theory subjects to match the practical instead of being taught in isolation. Lecturers also stated that improving students' practical skills was important due to the fast changing technologies in the engineering sector. 
Students also suggested that pre-apprentice programs should be a prerequisite for gaining employment as an apprentice. Similar recommendations were made by the lecturers for pre-employment programs to be made compulsory, before apprenticeships were initiated. Lecturers suggested an alternative model that could improve training: a combination of full-time employment with concurrent two-day release of training courses. Employers agreed that pre-apprenticeship training was beneficial prior to entering the workforce as an apprentice.

For apprentices, two weeks per year of block course training was rated as being insufficient, therefore, training time was an issue. Lecturers agreed (as indicated earlier in the chapter) and they suggested returning block courses to an achievable length for the apprentices. The lecturers also suggested that the current courses were inadequate to deliver the amount of training required. Nonetheless, employers were of the opinion that the current length of block course training was sufficient and did not require changing.

Apprentices indicated that correspondence material was a concern as assignments were not being sent on time. There was a request that online training should be an option rather than the current paper based system of assignment materials. Improvements required gaining additional support from employers for training, for instance, fixing payments for apprentices to attend off-job training courses. Apprentices believed that employers needed to be consistent and to pay apprentices for training as some were unable to attend training courses unless they took annual leave.

Apprentices said that to advance their training at the workplace there was a need for work to be made available to them. There is a current lack of suitable jobs that apprentices are able to work on to complete assessment tasks, which restricts their ability to complete their qualifications. Employers agreed that in certain workplaces, due to the nature of the work that was carried out, there was a need for apprentices to go to other workplaces in order to complete required tasks and assessment.

\subsubsection{Assessments}

Apprentices in the refrigeration/air-conditioning/electrical groups indicated some confusion about certain theory assessment questions, and stated that improvement was 
required. Lecturers agreed that improvements were required to update methodologies for assessment. The students were of the opinion that a more determined plan should be instigated to ensure integration of theory and practice to provide authentic assessments for both pre-apprentices and apprentices. Employers suggested that some assessment was over the top and that certain questions asked in the theory assessment were irrelevant. Theory assessment tasks required upgrading to attain current industry standards, and a review was suggested by employers to determine suitable methods for delivery.

Apprentices indicated that some practical assessments were invalid and not fit for purpose, requiring rewriting in some circumstances. Apprentices acknowledged concerns about on-job learning and assessment, and a number of possibilities for improvement were suggested, including sufficient time to achieve off-job learning. Lecturers agreed that learning and assessment practices at the workplace needed to be improved. In terms of practical assessment, lecturers thought there was a necessity to investigate project based methodologies as a preferred option across both disciplines. Comments by apprentices relating to the standard of assessment occurring at the workplace were that in some it was alleged invalid and definite improvements were deemed desirable.

Apprentices indicated that there was an apparent need to train more on-job assessors for the workplace, as there were insufficient assessors to assess the numbers of apprentices needing to complete their apprenticeship. Apprentices were concerned that a conflict of interest existed with on-job assessors, for instance, in a number of cases the assessors were also their employers. A possible solution suggested by lecturers was for the Institute to provide on-job assessors as an alternative option, as for some apprentices it was difficult to achieve on-job assessments. However, employers did not agree that there were issues with assessment at the workplace.

Other improvements to assessment processes were suggested, with smaller companies unable to assess students regularly due to insufficient work able to be assessed. Suggestions made by employers included increased cooperation between companies to send apprentices to other workplaces to gain experience and complete their assessment tasks. 


\subsubsection{People skills}

Students indicated that the development of people skills was lacking within the preapprentice program. Recommended topics for learning included: communication skills, work ethics, team work, customer service skills and self-learning. Another suggestion was assistance in career planning, for instance, how to source a job in industry. Lecturers also considered that people skills were an important factor in training, and as determined by the students, the lecturers were of the opinion that people skills should be incorporated within the programs. Lecturers saw value in improving students' people skills as they had issues with a number of students within the program who lacked discipline, for instance, being late to class and work experience. Employers identified people skills as a requirement for the Institute to integrate into the programs as a compulsory component. Specific training for employment interview techniques and curriculum vitae writing would be considered a definite improvement. Enhanced screening of applicants was deemed necessary by the lecturers prior to students' entering the pre-apprentice program, ensuring that numeracy and literacy skills were of a sufficient standard.

\subsubsection{Work experience and the workplace}

The pre-apprentices found that work experience was one component of the training program that was difficult for a number of them to achieve. A suggested improvement was to have work experience provided and arranged by the Institute. Students stated that they definitely needed more help to find suitable workplaces to undertake their work experience. Once in the workplace, pre-apprentices also indicated that they needed to have more time, as currently time spent in the workplace was insufficient.

The lecturers also indicated that work experience needed to be fully supported by the Institute, to provide the pre-apprentices with the opportunity to engage with the workplace and gain on-job practical understanding. Not only was work experience considered a necessary component of the full-time program, but it also needed to be of good quality. It was considered that insufficient on-job training was occurring in some workplaces which needed addressing. Employers indicated that all students attending full-time pre-apprentice programs needed to attend work experience, and that it should be a compulsory part of the program. 
Apprentices suggested that learning was not always occurring within the workplace environment. Some apprentices had difficulties in achieving the necessary on-job learning due to the scope of work available, and it was suggested that some workplaces needed to update their technology.

Resources at institutes (and for a few employers) were at times seen as a barrier to completing certain tasks and assessments. It was suggested that improving partnerships between stakeholders could be a possible solution to alleviate such difficulties.

\subsubsection{Industry Training Organisations}

From an apprentice perspective, improvements were required from the ITO managers to ensure that apprentices were working to an agreed training plan, and were on schedule for achieving their unit standard assessments. Lecturers indicated that enhanced support from the ITO was required to arrange increased apprentice training time on block courses. Comments by lecturers pertaining to the course material supplied by the ITOs suggested that standards needed development. The employers suggested that the ITOs needed to provide additional industry support along with the ITPs.

\subsubsection{Career pathways}

Lecturers suggested improving the pre-apprenticeship/apprenticeship training programs by developing improved relationships with high schools. The intent was to engage students into chosen pathways through the pre-employment option prior to entering the workplace. This would provide students with improved opportunities to gain successful employment in industry.

From an employer perspective, pre-apprenticeship training programs were the preferred option to direct apprenticeship training. Employers indicated there was no room for complacency as engineering is a fast changing industry and it is important to keep pace with technological change. It was important in terms of complexity for training courses and curriculum to be up to date to meet the needs of industry. 
The respondents made several suggestions for improvement in terms of career pathways for apprentices. They indicated that a significant amount of work is required to ensure that apprentices are able to complete their apprenticeships to become fully qualified technicians.

\subsubsection{Conclusion}

This section of the chapter identified and presented the possible improvements that were suggested from the findings from all of the participants groups involved in the study, including pre-apprentices, apprentices, lecturers and employers. In Chapter 5, the findings are critically discussed and analysed in detail based on the underlying themes pertaining to the research questions. 


\section{Chapter 5: Discussion and Analysis}

\subsection{Introduction}

This chapter discusses and analyses the research findings presented in Chapter 4. It is organised to consider and address the main research question, and to critically discuss the four sub-questions. The findings from the previous chapter that discuss the experiences, perceptions and opinions of all the participants (pre-apprentices, apprentices, lecturers and employers) are discussed and analysed. A detailed discussion of the themes that are linked to the research questions (from the questionnaires, focus groups and interviews) are also considered against the literature review. Throughout this chapter the data gathered will be critically discussed relating to similarities or contrasts within the literature. The chapter also identifies new knowledge which contests current literature pertaining to pre-apprentice learning and training programs.

\subsection{Research Questions}

The main research question for the study was:

What is the relative effectiveness of features of pre-apprenticeship and apprenticeship modes of delivery in engineering trades?

To address the main research question, the four research sub-questions will be discussed sequentially. The research sub-questions were:

1. How do different parties (employers, students, lecturers) view the different modes of training?

2. What are the benefits and challenges of different modes of training for engineering trade occupations in New Zealand?

3. What learning and assessment practices contribute to high quality in the two modes of training?

4. What improvements could be made to quality? 


\subsection{Discussion of Research Questions}

\subsubsection{Research question 1: How do different parties (employers, students, lecturers) view the different modes of training?}

The pre-apprentices considered that substantial skills were achieved when they attended the pre-employment program. For instance, they found learning knowledge and skills through their coursework to be valuable, and in particular, practical training proved to be beneficial when going into the workplace. Having the knowledge to be able to diagnose problems and understand how to carry out repairs on vehicles and machines was considered to be an advantage. As previously described, a significant benefit for pre-apprentices was the ability to gain a position as an apprentice at the workplace, as employers were more likely to employ pre-apprentices as they had recognised attributes to start an apprenticeship at year 2 .

In relation to students' views on the arrangement of courses within the full-time preapprentice program, incidents were identified as having occurred pertaining to the timing and the number of specific topics within the program. For instance, it was reported that there was a lack of training time for practical activities to be undertaken, particularly in the refrigeration/air-conditioning/electrical discipline. Apprentices also criticised the length of block course training as being too short. These were areas seen to require future re-developing and improving by both staff and students.

Further improvements pertaining to on-job work experience for pre-apprentices was to ensure suitable arrangements were made for them to attend the workplace in future programs. Similar to when an employer decides to deliver training at the workplace, work plans must be instigated to ensure that training is arranged with staff in a position to train. In regard to workplace training, the Industry Training Federation (ITF) (2007) states that experienced workers play an important role in learning for apprentices. As indicated in the literature, once an apprentice signs an agreement there are certain responsibilities for all parties to the agreement, including the apprentice, employer and training organisation (Tertiary Education Commission, 2016). Apprentice agreements determine the qualifications, standards, delivery modes, achievement targets and reporting framework. 
The majority of the pre-apprentice respondents in all groups considered that the practical hands-on work at the workplace was a key component in helping them gain practical capabilities in undertaking real work. Industry experience was quoted by the pre-apprentices as being important and worthwhile prior to being employed, and it was necessary to be included in the programs. Similarly to the findings in Chan's (2011) study, the apprentices in this study reported that they were aware of the time and effort that was required to learn and to gain practical skills to underpin the knowledge gained. Industry on-job training leads to apprenticeships and should be encouraged. In terms of work experience, the lecturers found that there were significant benefits associated with pre-apprentices attending the workplace to gain relevant experience pertaining to a specific trade.

Where students are able to successfully obtain a position as an apprentice as a result of their attendance at the workplace, this is of course a sought-after outcome, and for all intents and purposes, is deemed to be the preferred result. However, as a consequence of pre-apprentice students gaining industry employment during their program, they are then unable to complete their program as a full-time student. The New Zealand Tertiary Education Commission (TEC) (2016) states that students leaving full-time programs of study early are deemed to be unsuccessful. As previously indicated in the findings, this situation creates issues for both the lecturers and the institutes as the students leave the program without completing their qualifications. However, once employed and signed onto a training agreement as an apprentice, their training will be continued through on-job and off-job arrangements, enabling completion of their final qualifications through a contract with the ITO and their employer in the relative field.

\subsubsection{Workplace learning for pre-apprentices and apprentices}

As Billett $(2001,2009)$ clearly states, for good quality learning to occur, a key factor is the workplace's "readiness" to provide opportunities for learners to engage. Vaughan (2008) cites Simons (1995), who argues that one possible approach to workplace learning could be "forms of intentional, structured, and organised learning on the job that have an explicit pedagogic strategy. These aim to develop competencies of employees by supporting, structuring, and monitoring their learning through different principles" (p. 4). Comments made by both groups of pre- 
apprentices indicated that their experience appeared to be one that was supported, and the technicians at their workplaces were instrumental in providing training.

When considering support in the workplace, employers were of the opinion that more support would be beneficial if industry and training institutes were to encourage improved working partnerships (Vaughan, Neil, \& Cameron, 2011). They indicated that employers in the engineering industries were the experts in the latest technology and would be able to advise necessary curriculum updating to meet ongoing changes. It was absolutely critical that pre-apprentices were exposed to new technologies, and this could only be obtained through engagement at the workplace. Industry would further benefit through engaging pre-apprentices who had knowledge and skills applicable to working with technologies.

As Chan (2011) identified in a study on pre-apprentices and apprentices, it is crucial for students engaged in on-job learning to be exposed to authentic learning to build the knowledge and skills required. Comments from employers indicated that it was encouraging for students to become an asset to them after being trained in a practical way at the workplace. For knowledge to be demonstrated effectively it is considered essential to be integrated with practical training. The Industry Training Federation of New Zealand (2007) reported that when experienced technicians took on the responsibility of supporting training and assessment at the workplace, it was advantageous for all concerned, particularly for apprentices and pre-apprentices.

A number of employers advocated that good training was occurring at the workplace and pre-apprentices and apprentices were developing good communication skills. When pre-apprentices were placed with technicians working on real tasks, they gained hands-on experience on-job, not only with the technical aspects of the work, but also when the technicians interacted with customers. However, employers indicated that prior to pre-apprentices entering the workplace for work experience it would be beneficial for courses to include training in life skills and employment interview techniques. This is supportive of the work of Aarkrog (2005), who showed that tailoring apprentices' off-job and on-job training is favourable to improving their achievements, and leads to enhanced lifelong learning. A higher level of basic skills was also seen as an important issue, as good reading, writing and numeracy levels, for 
instance, are necessary to work in engineering industries where problem solving is a key requirement.

When considering modes of learning, one employer was adamant that prior to any training being undertaken, it was more beneficial for apprentices to go direct into the workplace. Reasons given in support of this option included the belief that being placed into the field first would enable an apprentice to become established in the way of work. Once the apprentice was competent, off-job training could then be arranged at a later time. Nevertheless, other employers expressed a view that when they had employed new apprentices in the past, these apprentices were not always ready for work and were sometimes given menial jobs that were not helpful to gaining skills and knowledge in industry. It was reported that for a number of workplaces, adequate training plans were not available, and as a result apprentices were not able to complete their training. As Vaughan, Gardiner, and Eyre (2012) determined, a training plan is a key tool and contains details about the apprenticeship process to enable successful outcomes for the apprentice.

It also seems that for a large number of apprentices, their employers will not provide paid leave from work for them to gain access to off-job training. As a result, some apprentices do not receive any pay whilst attending off-job training courses. Apprentices were of the opinion that when attending training courses, insufficient resources were allocated for travel and accommodation. A number of apprentices in the refrigeration field travelled long distances to attend courses and were required to fund their own expenses.

Further practical activities seen as important included: work experience; increased onjob learning from institutes in conjunction with workplaces; visits to workshops prior to going into industry; peer learning at workshops; and understanding specialised skills, i.e., brake technologies and heavy vehicle work. It was mentioned that there were some difficulties for employers in having apprentices due to the cost and the risk that apprentices can be a liability if damages occur at the workplace. For some employers, there was difficulty in understanding how the apprentice training system was supposed to work and they found this frustrating. There were some apprentices who sometimes found keeping track of their training plan with the ITO difficult. 
Understanding previous units of learning and assessments that had been completed were also not always clear.

\subsubsection{Research question 2: What are the benefits and challenges of different modes of training for engineering trade occupations in New Zealand?}

This research question will be discussed across the different modes of training focusing on the benefits and the challenges that pertain to the two engineering domains studied.

As referred to in the literature review in Chapter 2, pre-apprentice programs have become an alternative option for students who have chosen to study full time, rather than enter directly into the workforce as an apprentice. As indicated in the literature, the numbers of pre-apprentice students within New Zealand who have taken up places in full-time structured learning programs have grown considerably. During the period from 2012/13 to 2014/15, the growth in numbers of students enrolled in full-time tertiary education up to Certificate 4 increased by over $25 \%$ from 46,988 to 62,650 . The numbers of places in industry based apprenticeship training increased during the same period by only 1,000 - from approximately 21,000 to 22,000 (New Zealand Ministry of Education, 2015). This statistic is particularly relevant to this research as full-time pre-apprentice students in the engineering trades have grown considerably, whereas apprentices requiring off-job training courses have been static over the same period.

\subsubsection{Work experience benefits and challenges}

Respondents in this study indicated that during the pre-apprentice program there were definite benefits from positioning themselves to explore potential apprenticeships in industry. This was made possible by finding work experience and creating opportunities for students to meet others in industry and to gain insight into what an apprenticeship would consist of. For students engaged in a full-time pre-apprentice program, the findings from the lecturers agreed that an important benefit of the program was industry engagement for the students during work experience. 
Even though work experience was considered to be effective and worthwhile, as confirmed by the New Zealand Ministry of Education (2012), the findings from this study indicated that work experience was not always as effective as reported. A challenging feature of the pre-apprentice training that emerged from the data was that for some students, finding work experience was a major setback. The work experience component required students to find and arrange their own work placements. Some students who were unable to find work experience had not received the experience they needed in a particular trade. However, the majority of respondents contended that work experience was a valuable benefit of the pre-apprentice program and that it should be mandatory for all students. As indicated by Dessinger, Smith, and Pickersgill (2008), the Australian system for pre-trade programs incorporates work placements that require specific tasks to be achieved at the workplace. It might be argued that in the New Zealand context, similar activities including obligatory work placements could be explored as an option for future pre-apprentice programs.

A significant finding relating to work experience emerged from the lecturers involved in the study. Through industry engagement with employers the lecturers formulated enhanced relationships that resulted in benefits not only for the students but also for the lecturers themselves. All the lecturers were supportive of work experience for the students and firmly believed in the advantages for pre-employment programs.

As previously determined in the findings (Chapter 4), several benefits were identified in terms of the work experience component. For instance, students cited that attending work experience gave them a fuller understanding of the trade they would transition into. They would receive full training towards their theory and practical requirements to meet the needs of the workplace, and a majority of graduates believed they would go on to gain employment, or actually did go on to gain employment in a specific trade. Lecturers also advised that they received significant benefits from making regular contacts with industry, particularly in relation to students' work experience. For instance, employers were more engaged and supported students attending the workplaces, which resulted in important contacts for the lecturers and where industry experience also became available for them. Employers not only made visits to the Institute but they also contacted lecturers to find suitable candidates for apprenticeships. These findings support the earlier Australian report by Dumbrell and 
Smith (2007) that pre-apprenticeships broadened the number of apprentices in the workplace and prepared pre-apprentice students for an apprenticeship by providing exposure to the workplace. The findings also supported the notion that there is a place for both pre-apprentice and apprentice modes of training for industry. If students had not enrolled onto the pre-apprentice program, then they would not have had access to work prospects and obtained job leads from the lecturers. Thus, it was important for them to attend work experience opportunities at designated workplaces during their on-job training.

\subsubsection{People skills development}

Pre-apprentices felt that training in people skills was deficient in providing suitable preparation for the workplace. To be a good tradesperson, clearly important attributes included skills relating to customer service, people skills and good communication.

'Communication skills' and 'problem-solving skills' in the so-called 'new workplace' are defined specifically as those that enable team members to overcome any resistance (their own or others) and to embrace the goals, terms and conditions of work desired by the employer. (Jackson \& Jordon, 2000, p. 206, as cited in Vaughan, 2012)

Although it was evident pre-apprentice students had gained a good sense of what was required at the workplace through their workplace experience, there were difficulties for a number of students in working unsupervised in a work environment. As indicated in the findings, included in people skills is the need to understand work ethics, for instance, requirements for attending the workplace on time.

For apprentices, presentation concerning dress and manner when talking with others at the workplace was seen as important, as was ensuring that they were aware of the workplace culture and work attitudes. As Chan (2012) indicates, when workplace learning is included in programs of study there are additional requirements that tertiary educators should be trained in to be effective in delivering relevant knowledge. Chan states that particularly for staff who have trade based knowledge, "the inclusion of theories of learning pertinent to workplace and trades-based learning and teaching workplace expertise of trade workers is necessary" (2012, p. 418).

The issues in the study findings pertaining to people skills development showed that considerable challenges existed for both modes of training. Responses from all 
respondent groups indicated that there was no formal tuition given in people skill development in either mode of training. Additional tuition was needed in communication skills and in understanding workplace requirements in terms of life skills, employment interview techniques and writing references for students to gain employment.

\subsubsection{Learning benefits and challenges}

This section discusses findings from the study in relation to learning benefits and challenges, including work readiness, training support, integrated learning, and balancing levels of learning.

\subsection{Work readiness}

There were substantial benefits for pre-apprentices through the hands-on practical learning undertaken in the program. In particular, responses relating to the practical based projects were very constructive where students were required to work on projects as part of their practical learning. A considerable benefit cited from working on practical projects included using trade tools and equipment that had not been used previously. This led the students into a "work readiness" mode, particularly by experiencing simulated work processes that were critical for success once they were at the workplace.

Providing delivery programs for trade based industries and preparing students with the knowledge and skills required were key objectives for the ITPs in New Zealand (New Zealand Ministry of Education, 2012). As alluded to by Wareham (2012), preapprentice students engaged in such activities gained experience and skills that would be required in industry. However, challenges presented when considering the modes of delivery, and in particular, in terms of practical based learning. The findings also indicated a degree of frustration about timeframes available for practical projects due to the insufficient length of time allowed to complete projects at the ITP.

Additional issues that were considered as further challenges to the pre-apprentice programs were related to the amount of practical and theory classes offered during the courses. Chan (2011) states that for students working towards meeting their required graduate profiles, learning and assessments must match the occupational tasks at the 
completion of a program. For blended learning, further opportunities available as a result of using this method of delivery were deficient due to limited access to the Internet. This was seen as an issue as some of the teaching and learning was delivered through the student and learning online system.

The study highlighted benefits for apprentices in both the refrigeration/airconditioning/electrical and automotive disciplines, and findings clearly indicated that being an apprentice was satisfying in the context of working and being paid to learn. A large number of apprentices valued the learning they had achieved through working on-job and felt they had learnt a wide range of skills conducive to meeting the requirements of the workplace. As determined by Vaughan (2008, p. 23), "While pedagogy (strategies for teaching and learning) is important, it is the culture of a workplace and the way that learning is organised and supported in a workplace that sets up what can be learnt and how it is learnt". For instance, this can be accomplished when workplace technicians mentor the apprentices, assist them with their training plans and provide guidance in meeting the requirements of on-job work and assessments.

\subsection{Training support}

The apprentices considered that a bonus of achieving assessments and reaching the next levels was receiving additional pay. The data showed that apprentices who had transitioned from pre-apprentice programs were usually more motivated to learn, and better prepared for the workplace compared to those who had not done pre-apprentice courses. Indeed, comments from employers in the automotive field concurred that when employing apprentices, those who had completed a pre-apprentice program were more informed about the nature of the work required at the workplace.

The notion of ensuring the apprentices had adequate training is supported in the literature (Chan, 2013b), which states that the main objective for apprenticeships is receiving adequate training to become competent tradespeople. Encouraging comments made by the apprentices in the study identified that there was good practical based learning occurring in a number of workplaces. This supported the need for the apprentices to gain practical hands-on experience working with engineering tasks and the safe operation of hand tools and equipment. Employers agreed that the 
safe operation of tools and equipment in the workplace was essential. These findings were supportive of the first year perspectives from the work completed by Chan (2011), who examined why apprentices continued with their specific career paths in the trades they selected. Comments were also made by pre-apprentices pertaining to receiving additional support and the knowledge that someone with advanced knowledge was available to assist them if they had difficulty in understanding how to accomplish certain tasks or work requirements.

Nonetheless, challenges were reported in the findings relative to apprentices. Significant difficulties were highlighted by apprentices in both disciplines in relation to completing the on-job requirements at the workplace. In certain situations, it appeared that employers were not able to support training and there were concerns that the workplace was not conducive to a good learning environment. The Industry Training Federation of New Zealand (2007) specifies that for effective training to occur at the workplace, support from employers and ITOs is a key requirement to enable apprentices to succeed and complete their apprenticeships. Vaughan, Gardiner, and Eyre (2012) also determined that a training plan is a critical tool to ensure that the apprentice, employer and industry work together to reach a common purpose.

\subsection{Integrated learning}

As indicated in the findings for the lecturing staff, the most satisfying outcomes when teaching apprentices or pre-apprentices was the opportunity to engage the students in practical learning activities. There was notable interest by the staff in both disciplines in researching new technologies that enhanced learning for the students. The lecturers teaching on both the full- and part-time programs were extremely keen to share their own experiences and expertise with the students.

In terms of the pre-apprentice programs, the lecturers were of the opinion that the programs were significantly useful as the students were able to spend considerably more time engaged in full-time study. For instance, during their one year as a preapprentice, students complete 120 credits or 34 weeks of learning towards their national certificate. This contrasts with automotive apprentices in their first year on the job who are only able to complete a minimal amount of study through off-job training, averaging 34 weeks of night classes (of two hours duration) and two weeks at 
a block course. Refrigeration/air-conditioning/electrical students carried out a similar amount of study through distance learning and attendance at two weeks of block course off-job training. An apprentice in either discipline, without studying full time, would take on average four years to complete an apprenticeship (Motor Industry Training Organisation, 2016).

As Wareham (2012) found through his study with pre-trade students in the plumbing field, students have a tendency to be more motivated to learn a trade through a pretrade program. Students are in a far better position to focus entirely on their career paths before going into industry as an apprentice. Once working in a trade as an apprentice, students can no longer spend the same amount of time on their study component compared to a pre-apprentice student.

The lecturers in the current study identified that significant benefits for off-job training included the training received by apprentices when engaged in integrated practical and knowledge activities. An important feature was for apprentices to be engaged with staff and to discuss in-depth material while attending a block course to gain a clear understanding of the curriculum. On their return to the workplace after their training courses, apprentices were able to put their training into practice and showed definite improvements in real work.

The New Zealand Ministry of Education (2012), through its review of industry training with apprentices, found that a significant number of employers found the preapprentice courses to be valuable, as graduates had gained a good knowledge of their industry, had useful practical skills and were committed to succeeding in their trade. The courses were also seen to complement and provide a clearer understanding of how tasks were practised within the workplace and students' responsibilities when engaged there as pre-apprentices. Gaining qualifications by attending pre-apprentice training programs was seen as a definite advantage for those students choosing to study on a full-time training arrangement. These students gained the benefit of a quicker timeframe to graduation. This would not be possible if they had chosen the alternative pathway of working full time as an apprentice and studying part time. 


\subsection{Balancing levels of learning}

Difficult or frustrating issues included balancing the levels of learning within the groups of pre-apprentices. These issues proved to be frustrating and challenging for the lecturing staff due to deficient school level education of a number of preapprentices. This had an ongoing effect on learning at tertiary level with the belief by potential students that learning a trade was just a manual occupation and that a reasonable academic level was not required.

The apprentice groups reported some frustrating issues, particularly when they attended off-job training. A number of apprentices had not completed the required theory study or had recently started an apprenticeship and were sent to training when not prepared due to a lack of understanding of subject matter. A number of comments were also made by the lecturers concerning the quality and amount of on-job work experience completed by pre-apprentices and apprentices at the workplace. A number of apprentices reported that suitable jobs were not available for them to meet certain unit standard assessment tasks. For a few staff, the lack of discipline of a number of students was also an issue, for instance, lateness to classes and failing to complete self-directed learning assignments. In addition, a few pre-apprentice students showed a general lack of commitment by not meeting the course requirements and falling behind with their studies.

For employers, one of the most satisfying outcomes from pre-apprentice training courses was the trained apprentices eventually available in the industry. Employers were most satisfied about employing graduates from the pre-apprentice programs, continuing to train apprentices to a high standard, and retaining them for the long term. The general consensus from employers was that they believed the pre-apprentice programs were worthwhile as students gained far more in-depth knowledge and practical skills, and achieved further confidence in preparation for employment at the workplace.

Transitioning into the workplace from a pre-employment program allowed preapprentices to enter the workplace with solid knowledge and an ability to be immediately productive. For example, students would have completed all the safety requirements and met the standards for the workplace. They would also have learnt all 
the fundamental knowledge and skills that pertain to their trade at level 3, have practised in a simulated environment, and many would have already experienced real work practice at the workplace. A significant benefit for pre-apprentice students was the opportunities leading towards full employment as apprentices. Once engaged in workplaces, the pre-apprentices had a greater understanding of work requirements and were able to work with limited supervision. Nonetheless, when employers employ apprentices they also accept the responsibility to engage them in on-job learning. As indicated by Brown (2003), the effectiveness of the workplace training is only as effective as the partnership between the employers, apprentices and the training organisation.

A challenging matter that was raised by a few employers was the importance of students having the correct attitude towards employment. Opportunities for employers to evaluate students occurred when pre-apprentices were searching for work placements and carrying out work experience. A full understanding of a trade was noted as a key component in order for the most suitable students to enter the trade; otherwise, entering into the wrong trade could prove problematic not only for the students but for the employers. The research by Chan (2011) on perspectives of New Zealand apprentices and pre-apprentices was extremely valid and related well to this study, as new apprentices entering into a workplace depended on workplace support, engagement with the workplace, and a sense of belonging.

A difficult issue that was evident in the data was the standards reached by a few graduates from the pre-apprentice program. In some instances, employers had employed pre-apprentices and found that they were not suited to their workplace. As a consequence of employing students below standards, employers have suffered unfortunate experiences employing these students as apprentices. For instance, comments were made relating to students' attitudes, timekeeping, communication skills and general work ethics.

In terms of training apprentices, a few employers were of the opinion that there was insufficient practical, hands-on training provided by off-job training. Comments indicated that training should be less about theory and more about the practical and operational aspects of components. More practical training was needed off-job and an emphasis on how theory relates to the real world of work. Suggestions included 
improving practical training courses to better integrate the theory components in order to illustrate that the theory has been learnt and can be demonstrated in a more efficient way. As indicated in the findings, a few employers were not convinced of the benefits of the off-job training occurring at the Institute. A number of employers thought that life skills and attitudes were better taught at the workplace as the more appropriate venue for this form of training.

\subsubsection{Research question 3: What learning and assessment practices contribute to high quality in the two modes of training?}

A key question for this study was to determine the learning and assessment practices that contributed to high quality in the two modes of training for pre-apprentices and apprentices. This section will discuss and analyse the findings from the previous chapter in detail to determine how effective current practices were in terms of learning and assessment with a view to considering possible improvements.

Two aspects are relevant when considering the question pertaining to assessment: the first is gaining an understanding as to how knowledge is gathered to determine if learning has transpired; and the second is to gather enough evidence to determine practical capability. Assessment requirements in pre-apprentice and apprentice programs are considered through theory and practical assessments. As indicated by Vaughan and Cameron (2009, p. 6), "assessment is an important part of the learning process and learning 'product'. Certain kinds of assessment can actually support learning (increase it, help it take root, help make it meaningful etc.)". The New Zealand Qualifications Authority (NZQA) is the governing body that set up the national assessment framework and assessment standards for the purpose of assessing learners to recognised qualifications. The three main components are to ensure clear outcomes, application of consistent standards to the learning outcomes, and for knowledge and skills to be recognised and credited on the learner's Record of Achievement (New Zealand Qualification Framework, 2016).

Theory assessment is conducted with pre-apprentices at the Institute. A number of respondents indicated that the assessment process worked effectively and was appropriate. For instance, the majority of students were supportive of the way that 
assessment formatively checked how much they understood of the knowledge gained. However, there were mixed responses from the refrigeration/airconditioning/electrical pre-apprentice groups, indicating that occasionally the theory assessment was out of phase with the timing of the practical assessment activities. As a result the lecturers considered that assessments would be more beneficial to the students with accurate timing of theory to the practical activities. They determined that students would be more suitably equipped to be assessed on knowledge once the practical tasks were completed. For instance, there was some confusion from the students about what the theory assessment questions were actually asking. The questions needed to be clearer and redeveloped to ensure that the theory assessment would be thoroughly understood by future students.

As previously discussed, there were some thoughts given by lecturers to improve the delivery of theory assessment, for instance, the possibility of a holistic model of assessment to be introduced where the theory and the practical assessment tasks were integrated. As Stenstrom and Laine (2007) demonstrate in their research on traditional assessment compared to practice orientated assessment, assessment from an integrated model was more effective than traditional methods of assessment conducted separately at the end of a course.

Successful methods of practical task assessment were highlighted by students on fulltime programs. Students were able to identify closely with real work activities in the workplace by completing project based assignments. The advantages of working on projects were that the final outcomes exemplified operational features and demonstrated student capabilities. Employers considered project based assessment to be a key component of the curriculum and an effective assessment method as projects were closely related to industry practice. When the project was completed, the overall assessment was based on the final outcome of the project work.

One or two refrigeration/air-conditioning/electrical apprentices indicated frustrating issues when attending off-job training block courses. They had concerns regarding the availability of assessors to carry out practical assessments during the training sessions. Concerns were also recorded about their distance learning, particularly regarding the assessment and marking of assignments such as inconsistencies in marking and returning papers. Frustrations were evident where apprentices indicated that some of 
the correspondence information was not relevant to the assessment. For a number of apprentices, employers were not forthcoming in releasing them from the workplace to attend off-job training. The respondents stated they would have to use their holiday time to attend and thus would unfortunately receive no salary. From the lecturers' perspective, for improved off-job training to occur, the time given for apprentices to study was insufficient, as the timeframe was substantially reduced due to funding constraints as determined by the employers.

As Timma (2007) concludes from research conducted in Australian workplaces, suggestions were made towards encouraging and supporting a form of learner accountability. Timma's study found that if apprentices were active in arranging components of their own assessment, then they would take control of their own learning and on-job assessment was seen as an extension of their regular work. This method of arranging assessments confirms the earlier findings of the work by Stenstrom and Laine (2007) in practice-oriented assessment that assessment is part of the learning process.

\subsubsection{Research question 4: What improvements could be made to quality?}

The final research question looks at what improvements could be made to quality in the programs for pre-apprentices and apprentices in trade training. As Mitchell et al. (2006) conclude from their research in Australia on critical issues in teaching, learning and assessment, quality was and remains the major focus for all participants in vocational education and training. Their study found issues pertaining to improving the quality of the programs being delivered that required further investigation. However, the majority view from this study was that the pre-apprentice programs were extremely useful and were essential for providing industry with quality apprentices. The consensus that emerged was that pre-apprentice programs should be compulsory for all new apprentices who apply to become tradespeople. A number of benefits listed included: essential knowledge and skills in preparation for industry; gaining on-job industry work experience; standardising pre-apprentices' training plans; and increased motivation and commitment (Wareham, 2012).

Skills less well covered in the pre-apprentice program were those related to people skills. Recommended topics included communication skills, work ethics, team work, 
customer service skills and self-learning. Also suggested was assistance with career planning, for instance, how to source a job in industry. According to the lecturers, there was a need to improve the level of people skills, as there were issues with a number of students within the program who lacked discipline, for instance, lateness to class and work experience. The New Zealand Ministry of Education (2012, p. 52) confirms the value in undertaking pre-trade training by stating:

Completing a pre-trade or industry-relevant qualification prior to beginning an apprenticeship or seeking employment was seen as valuable because, along with equipping applicants with practical skill, it showed the applicant had some knowledge of the industry and was committed.

All students attending full-time pre-apprentice programs needed to attend work experience, and this ought to be a compulsory part of the program and organised by ITPs recommended by lecturers. A useful suggestion from five employers was that all work experience activities by the pre-apprentices required a report completing by employers at the workplace. Connor (2005) identifies that through work related learning from study or experiences in or related to the world of work, students are encouraged to reflect and report on the work relevant skills they have developed (e.g., during work experience placements). A report would allow a full record of the learner's experience to be recorded which would provide students with evidence of their capabilities and would assist employers to more easily make employment decisions.

Not only was work experience considered a necessary component of the full-time program, but the experience also needed to be of good quality. Work experience was one component of the training program that was difficult for a number of preapprentices to achieve. There was a definite need stated for more assistance in finding suitable workplaces to gain work experience. Once in the workplace, pre-apprentices also felt more time for on-job training was needed as it was currently insufficient.

The refrigeration/air-conditioning/electrical participants suggested several initiatives to improve quality in the delivery of the pre-apprentice programs. For instance, in the management of classes and practical workshops, time was stated as being too short, particularly for the delivery of the practical workshop classes. When considering the delivery of theory and practical tasks, it was suggested that theory be combined with 
practical subjects through an integrated method of delivery. Students also demanded increased practical training (including projects), and suggested that theory needed to match the practical subjects instead of being taught in isolation. Recommendations were made by employers that additional practical hands-on skills were needed as these skills were lacking when students arrived at the workplace.

As determined by Mitchell et al. (2006) from their research on teaching, learning and assessment in Australia, quality is the main focus for all players in tertiary and vocational training. To enable quality programs for pre-apprentices, further suggestions were forthcoming by lecturers and employers in this current study in terms of entry criteria into the programs. For instance, they suggested ensuring that applicants to the program had achieved at least a level 2 National Certificate in Educational Achievement, in particular covering subjects in mathematics, English and science. Currently, the tendency for pre-apprentice programs in New Zealand is to allow all applicants places on the programs on a first come first served basis. Also, students progressing from high schools are under the impression that as the programs are deemed to be "open entry", there is not necessarily a requirement to have obtained sufficient knowledge in subjects at school, such as mathematics and English.

As employers identified in the findings, it was becoming more difficult to employ apprentices. One employer from the automotive trade stated: "The level of students is too low going into pre-apprentice programs, the technology is over their heads and we lose them. We need to produce technicians that can work on high tech cars dealing with electronics". An improved mechanism for selecting applicants for the automotive workplace was recommended as a key requirement that needed to be instigated by the ITPs.

The apprentice and employer participants in the study suggested improvements to the quality of apprenticeship training. In earlier research regarding traineeships by Favero (2003), similar issues were identified in training, for instance, a reluctance by some employers to release trainees for training, the time taken to travel to workplaces, and concerns about funding, to name but a few. For apprentices in the engineering trades, two weeks per year of block course training was rated as being too short, therefore insufficient training time was an issue. As indicated earlier in the chapter, a suggested improvement was to return the block courses to an achievable length for the 
apprentices as the current courses were inadequate to deliver the amount of training required. Another recommended improvement was gaining additional support from employers for training, for instance, fixing payments for apprentices to attend training off-job courses.

Quality correspondence material was a concern for those apprentices learning through distance as assignments were not being sent to apprentices on time. When the apprentices did receive the paper material it was reported to be below standard. Improvements suggested were to consider online training as an option rather than the current paper based system of assignment materials.

An alternative model of training proposed that perhaps would improve apprenticeship training was a combination of full-time employment with a concurrent two-day release for training courses. The apprentices and employers indicated that the current model is not conducive for learning and assessment activities as the block course release arrangement for off-job training is insufficient in terms of timeframe, and distance learning and night class training methods do not provide adequate learning support.

A similar model that could be considered against is the German model of training called the "dual training system". As described in the literature, the German model provides for students who wish to enter a vocational trade where students sign up with an employer as an apprentice and attend vocational training over perhaps 1-2 days per week while the rest of their time is spent working at the workplace. The key difference with the German model is the option for apprentices to attend off-job learning regularly and consistently to achieve their qualification. Respondents believed that apprentices in New Zealand would receive a better quality of training if their training was conducted weekly. The other main contributor to the continued success of the German dual training system is for school leavers to see apprenticeships as the preferred option rather than other avenues of career opportunities (Dessinger et al. 2008).

A suggestion was made for ITPs and ITOs to improve their communications to enable enhanced training and assessment delivery. Enhanced support from the ITOs was requested in terms of arranging increased time for training on block courses for the 
apprentices. Comments pertaining to the course material supplied by the ITOs suggested standards needed development. It was also suggested that the lecturers receive on-job training as an option to keep them up-to-date with the latest technology and requirements at the workplace. There was considered to be an element of insufficient on-job training occurring at some workplaces which needed addressing. The employers suggested that the ITOs needed to provide additional support for the apprentices with their off-job training at the institutes, and to improve their engagement with apprentices to evaluate best practice in order to improve training plans.

\subsection{Significant Issues}

The following section of the chapter discusses significant issues identified in the data that emerged separately from the research questions.

These issues are discussed under the following sub-headings:

- Types of training: Time for training, challenging, inadequate.

- Assessment: Validity, relevancy and timing of on-job assessment.

- Lack of support for key agencies.

- Work readiness.

- Learning for work as an apprentice.

- Hybrid apprentices.

\subsubsection{Types of training: Time for training, challenging, inadequate}

Significant issues were identified in the study that indicated that apprentices in both engineering disciplines were experiencing difficulties in achieving specific tasks towards their national qualification through lack of on-job learning and assessment requirements at the workplace.

As indicated in the literature review in a New Zealand context, there is a requirement for apprentices to complete a set amount of graduate profile competency outcomes to achieve a trade qualification on the New Zealand Qualifications Framework (NZQF). The process of achieving the graduate outcomes is completed through a combination 
of on-job workplace learning, off-job learning at an institute, and distance learning. To meet the final trade qualification, a total number of learning credits are required over a period of approximately 3-5 years. However, recent research into apprenticeships in New Zealand has highlighted that attrition and non-completion of qualifications are significant concerns. Nationally, only a third of apprentices have averaged a period of five years to achieve their qualifications while two thirds have left the trades and not completed (Vaughan, 2012).

Nine apprentices in this study, particularly from the refrigeration/airconditioning/electrical group, clearly indicated that the on-job training component had not been occurring as it should. Concerns were highlighted regarding training and assessment processes, and a number of particular issues were brought forward related to why the apprentices were not gaining their required learning credits. The study also confirmed that there was insufficient training occurring in the workplace in some cases. For a number of the refrigeration/air-conditioning/electrical apprentices, it was clear there were significant difficulties in learning how to do specific jobs as part of their work. The study indicated that for some apprentices, even after the training agreement had been signed through the ITO, training at the workplace was not effective. Data from some of the refrigeration/air-conditioning/electrical and automotive apprentices suggested that actual training at the workplace was not occurring and indicated that there was a lack of support from other workers.

Smith et al. (2011) determine that there are two matters that affect quality in traineeships in an Australian context: employer support and commitment to training. Clearly this aspect of training was also an issue for the apprentices who participated in this current study. The issue with training on-job is not a new problem; several commentators have acknowledged there are several factors that are significant when learning is attempted at the workplace. Smith and Betts (2000) report that the effectiveness of work based learning is directly related to the quality and effectiveness of the partnership agreement between the apprentice and employer. Indeed, comments made by half of the refrigeration/air-conditioning/electrical apprentices in the current study clearly highlighted that technicians (their supervisors) expected apprentices to work with limited supervision, support and instructions. It appeared that the main objective for these technicians was to achieve the work schedule required. As a result 
there was insufficient time to work with and train the apprentices, and if any training did occur, it was inconsistent and not conducive to coincide with any off-job training.

For some automotive apprentices, the data showed that there was often a language barrier in the industry due to some technicians not speaking English as their first language. As a result students had difficulties understanding job requirement instructions and work methods. As indicated previously, this problem of inadequate support and a flawed training plan flows through to apprentices not being able to achieve on-job assessment.

\subsubsection{Assessment: Validity, relevancy and timing of on-job assessment}

Previous New Zealand research on workplace assessment has highlighted concerns over the lack of rigour and validity of assessment practices and the ability of assessors in the workplace. There have also been concerns pertaining to the assessment evidence, moderation practices and evidence gained by assessors (Electrotechnology $\&$ Telecommunications Industry Training Organisation [ETITO], 2006; Pells, 2006; Vaughan, 2012). This research has highlighted that in the two engineering domains studied there are still significant inadequacies identified for workplace assessment in the New Zealand workplace. Initiatives have recently been introduced, specifically in the New Zealand construction industry, to enhance the way that training and assessment occurs within the workplace. For example, an assessment guide (Vaughan \& Cameron, 2010a) had been produced from a research project involving an analysis of New Zealand and international literature. The guide was produced primarily to assist ITO assessment staff and also to assist employers and on-job assessors to determine how to develop effective assessment systems and structures. The main objective of the guide was to "support the alignment of learning and assessment practices with assessment structures and systems" (Vaughan \& Cameron, 2010a, p. 1). The guide would be a very useful tool for both the engineering trade domains that this study has focused on to assist with effective assessment systems and practice.

The data from this research study has clearly shown that important issues affecting the ability of apprentices to achieve their on-job work assessment credits are not being addressed. For instance, one major concern was in relationship to the scope of work that was available at the workplace. Apprentices in smaller to medium sized 
workshops in the automotive field reported that the requirements of their qualification did not match the work that was available in the workplace, and as a result it was extremely difficult to practice competencies in some subjects. As a result, apprentices were disadvantaged as they were unable to gain a pass to achieve competency in their assessment. Not only were the apprentices in the automotive trade having difficulties, but it was also affecting those in the refrigeration/air-conditioning/electrical trade and they too were unable to complete the on-job learning requirements. Again, there was reference to the scope and availability of work that was conducive to achieving their required learning outcomes.

One limitation that is acknowledged in this study is that no interviews were conducted with Industry Training Managers from the ITOs to gain their perspective on training plans and assessments at the workplace. In the New Zealand context, on-job assessment is linked to a number of contributors for assessments at the workplace (see Figure 2.3). However, it is not always an easy undertaking for acceptable assessments to occur. As seen in Figure 2.3, a number of trainers and assessors are associated through on-job and off-job training and assessment roles but they may not necessarily carry out both roles.

This was reiterated by Vaughan and Cameron (2009) in the New Zealand context, who states that workplace trainers and assessors may not necessarily be the same people. In the workplace the people who are responsible for training apprentices can be employers, managers, technicians or external trainers. Those who carry out the apprentice training may also be responsible for their assessment; however, for a number of workplaces this is not the case and different individuals may be required to carry out the actual assessment tasks (Vaughan \& Cameron, 2009). The people who are authorised to conduct on-job assessment at the workplace must be registered assessors and/or lecturers or trainers with on-job assessor qualifications. These same people can also moderate assessment tasks; however, lecturers and trainers are responsible for internal moderation and the Industry Training Organisation (ITO) is responsible for conducting external moderation processes over the Institutes of Technology (ITPs) and Private Training Enterprises (PTEs). 


\subsubsection{Lack of support from key agencies}

The ITO is the key agency responsible for the training and assessment activities undertaken in the workplace. When an apprentice signs a training agreement, the ITO has the role of monitoring the apprentice through their training plan on- and off-job and is also responsible for the moderation of the assessment. The off-job training is contracted out to the ITP where the students carry out learning and assessment through block courses and evening classes or through distance learning. As part of the contract the Industry Training Managers employed by the ITO are responsible for ensuring that the apprentice completes the training plan at levels 2-4 to achieve their national qualification (see Figure 2.1).

Figure 2.1 shows the mode of training for apprentices. Figure 5.1 indicates how problems might arise, for instance, a possible delay in the apprenticeship agreement being signed (see box 2). Apprentices may have an insufficient number of suitable jobs available in the workshop preventing learning and assessment from occurring (box 3). Apprentices may be prevented from attending off-job courses and therefore no training is available for specific parts of the curriculum (box 4). There may be difficulty in attending night classes due to location of the institute or perhaps lack of support for distance learning training (box 5). Finally, apprentices might not complete their apprenticeship as a result of inadequate training and assessment activities (box $6)$.

The data from this study indicated that for some apprentices once the agreement has been signed there is very little contact from the Industry Training Managers. As a result apprentices are left to their own devices and try to achieve assessments through alternative means. The ITO has assessors who can carry out assessment on-job, but as they are limited in number, the norm is for an assessor employed by the company and who is located in the workplace to carry out the assessment. Assessors can be technicians, supervisors or even the manager at the workplace, but they must have the relevant unit standard assessment qualification to be able to assess. The training for an assessor consists of one on-job unit assessment standard that qualifies them to assess at the workplace. The apprentices reported that this system was invalid due to irregularities in the assessment process, and at times activities were not assessed 
effectively and no assessments were carried out at all. As the Industry Training Federation of New Zealand (ITF) (2007) stated, experienced workers play a crucial part in the learning and assessment opportunities for apprentices. From the data gathered from the study it is clear that the training and assessment processes require modifying to improve the training and assessment activities carried out at the

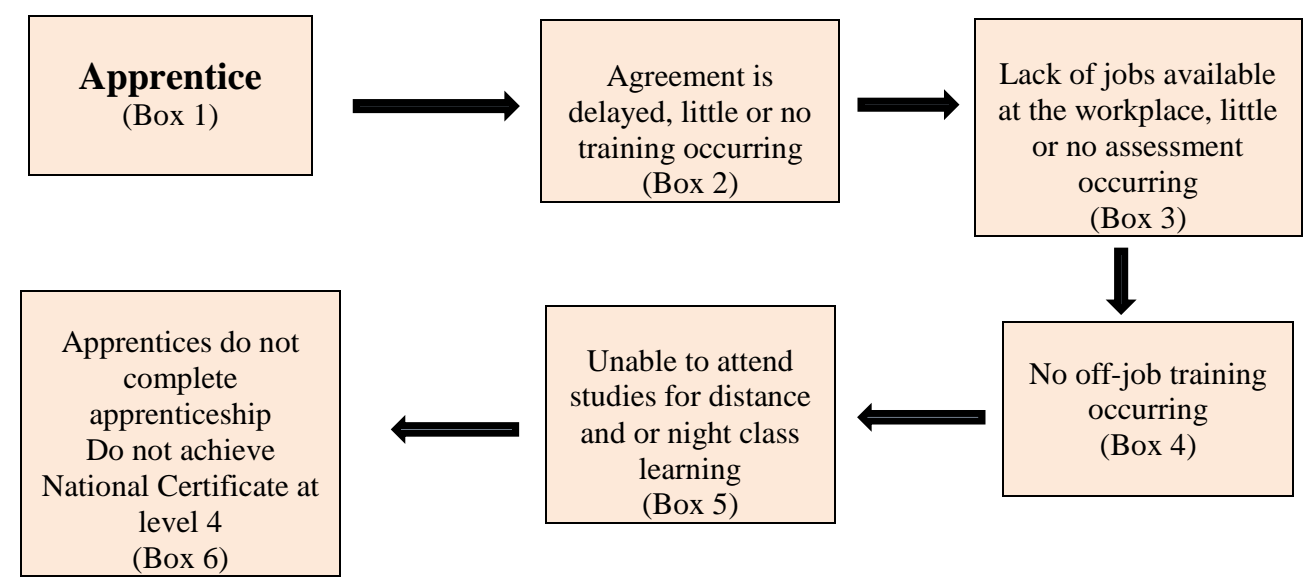

\section{Figure 5.1. Modes of training with challenges to learning and assessment resulting in non-completion of apprenticeship}

\subsubsection{Work readiness}

It is intended that students undertaking a pre-employment program will be ready to take up employment as an apprentice at the completion of the program. The data gathered in this study demonstrated that the majority of the pre-apprentice respondents who contributed to the research had in fact been either employed prior to entry into the program or were actively engaged in work during the program. For instance, in terms of the demographics of the students who were studying on the pre-apprentice programs in refrigeration/air-conditioning/electrical engineering, a significant number were over the age of 21 . The background demographic data gathered from the questionnaire showed that not only are pre-apprentice programs undertaken by school leavers, but also by mature students who are looking to change their career direction into alternative disciplines. For instance, pre-apprentice programs are suitable for school leavers, adult learners and existing workers, and are also possible for apprentices already working. The data indicated that pre-apprentice programs were useful in providing a substantial knowledge and skill base for the students in 
preparation for working in engineering workplaces. This confirmed the earlier research by Wareham (2012), who found that pre-trade programs provided specialist industry skills and knowledge in preparation for employment into engineering trade workshops.

With regards to the refrigeration/air-conditioning/electrical pre-apprentice students, a considerable number of the respondents had previously worked in the electrical field, other trade and non-trade areas. Of the 16 students interviewed through the focus groups (see Section 5.4.5: Hybrid apprentices), 10 students said that their current work was related to the course, three said they were working and three were non-specific. From previous work experience prior to the program, nine students said they had previously worked in some capacity. Only three students stated they had no prior work experience before entry into the program.

The data was similar for the automotive pre-apprentice group: 10 out of 14 students were currently working alongside their training program, and four students were not currently working. Six students said that they previously worked part time, and three had worked full time prior to undertaking their program. The categories of work that the students were engaged in included automotive workshops, construction work and non-trade work positions.

The issue related to "work readiness" (Callum, 2008; Wareham, 2012), is unclear, as the idea of students being only ready for work once they have completed preemployment programs is contested, as shown by this study. Most if not all of the students, both new and mature, had previously or alongside their study program been employed in some form of work. However, the types of work experience gained previously by a significant proportion of the respondents were considerably varied. One could argue that being "work ready" was perhaps more a case of contextualisation to specific work practice within an industry that the learner was preparing for.

As indicated in a previous study by Dumbrell and Smith (2007), the question relating to preparing students to be work ready was more about familiarising students to a particular trade rather than to workplaces in general. For both groups in this study, the main reason for studying the pre-apprentice program was to gain the relevant 
knowledge and skills pertaining to their new career choice, or learning for work in a specific trade. By undertaking work in other workplaces, the learning experience proved beneficial as the generic knowledge gained was crucial to continue on their career path as technicians in a trade occupation.

The students with previous and current work experience were clearly shown to be motivated learners as they had acquired essential and broad workplace skills. Typically, the skills that had been achieved provided the students with the attributes that were essential to continue their learning and work plan towards a specific trade. Through reflection on previous work, and undertaking informal and formal learning, the students were able to identify with personal values and ethics in the workplace.

By acquiring previous work experiences, students were also clearer as to the nature of employer/employee relationships. For example, the data showed that the students who had undertaken previous work practices could relate well to a number of conditions that they had exposure to. They understood how employer/employee relationships worked, they had the ability to carry out work responsibilities in a safe and competent manner, they were able to work alongside others, and they were able to learn the workplace cultures.

By entering into a pre-employment program with acquired prior knowledge, students were able to use that experience to enhance and allow for quicker learning in their course work and current work requirements. Learning specialised skills was essential to be able to diagnose and rectify problems when the students were employed at the workplace in an engineering context. A considerable bonus for pre-apprentices of attending a pre-apprentice program was a greater chance of gaining an apprenticeship on completion than if they had applied directly to an employer for an apprenticeship without studying such a program. Many industry employers were prepared to employ "pre-employment" students as their first option.

Out of the combined apprentices from both sectors engaged in the study, a total of six students out of 24 had previously studied as pre-apprentices. Compared to the apprentices, the data indicated that the pre-apprentices had gained significantly more credits towards their final qualification in a much shorter timeframe. As previously discussed, achieving credits at the workplace was particularly difficult for apprentices 
due to the issues of completing training and assessment requirements on-job. A number of apprentices, when they compared their training plan with the preapprentices thought that it may well have been more beneficial to have attended a preapprentice program prior to commencing an apprenticeship. The notion of work readiness for the apprentices pertained to preparation and acquiring knowledge and skills that would be more applicable for their specific trade. By attending the preapprentice program they would have experienced the trade knowledge, work experience and culture that would have given them an insight as to the type and variety of work that they would be exposed to when taking on an apprenticeship.

When the question of work readiness is considered, particularly for new apprentices or workers who are new to a workplace, Chan (2011b) determined that the workplace environment is an important consideration. According to Chan, a supportive workplace culture is crucial to welcome new apprentices and to help them join the workplace team and build relationships: "Newcomers are provided with opportunities to join the workplace team and to assimilate important work readiness skills, and are afforded prospects to observe the trade as outsiders" (Chan, 2011b, p. 204).

It was important to consider that a significant number of apprentices within this study were employed at workplaces where they may not have felt supported. As indicated by the data, difficulties for apprentices in utilising workplace learning opportunities and achieving knowledge prevented them progressing their learning at a reasonable rate. However, as Chan indicates, workplaces that are on the restrictive end of participation are not necessarily obstructive for apprentices to become effective tradespeople. Likewise, Chan (2011b) explains that expansive participative learning environments provide no guarantee that apprentices will achieve through using workplace learning opportunities.

An Australian research study completed by Karmel (2006) provided evidence that older groups of people were entering into apprenticeships that were already in employment. The types of work that were popular were in intermediate production and transport, and intermediate clerical, sales and service worker occupations. The inference was that substantial numbers of older people were entering into a career through an apprenticeship, and a key reason was to use apprenticeships to obtain training and qualifications to become qualified tradespersons. The main finding from 
the Karmel study indicated there were significant changes occurring within industry where the range of occupations had broadened, and that part-time apprenticeships were quite common. It was also noted that apprenticeships were no longer just for school leavers and that apprenticeships had become important for a range of age groups and also for both genders (Karmel, 2006). In terms of this current study, the findings showed that a significant proportion of the pre-apprentices were mature students who had considerable work experience prior to their program of study, providing evidence that being work ready had taken on a whole new meaning.

\subsubsection{Hybrid apprentices}

This study indicated that an emerging significant occurrence can be observed. A "hybrid" training situation was apparent where apprentices were attending programs of study that were normally intended for pre-apprentice students. It was found that 10 of the students from both the automotive and refrigeration/air-conditioning/electrical groups were already working as apprentices and had been instructed by their employers to attend the pre-apprentice program. This pathway that the research has uncovered is seen in Figure 5.2. This pathway differs from Figures 2.1 and 2.2 due to the hybrid students already in employment.

The new pathway for hybrid learners is unorthodox as under this scenario learners are accepted into the workplace and generally start an apprenticeship while simultaneously commencing a training program as a pre-apprentice. There appeared to be various reasons given for apprentices enrolling in pre-apprentice programs that were shown to be advantageous for the participants of this study. Some of the reasons evident included the objectives of obtaining knowledge and skills to enhance the workplace experience. 


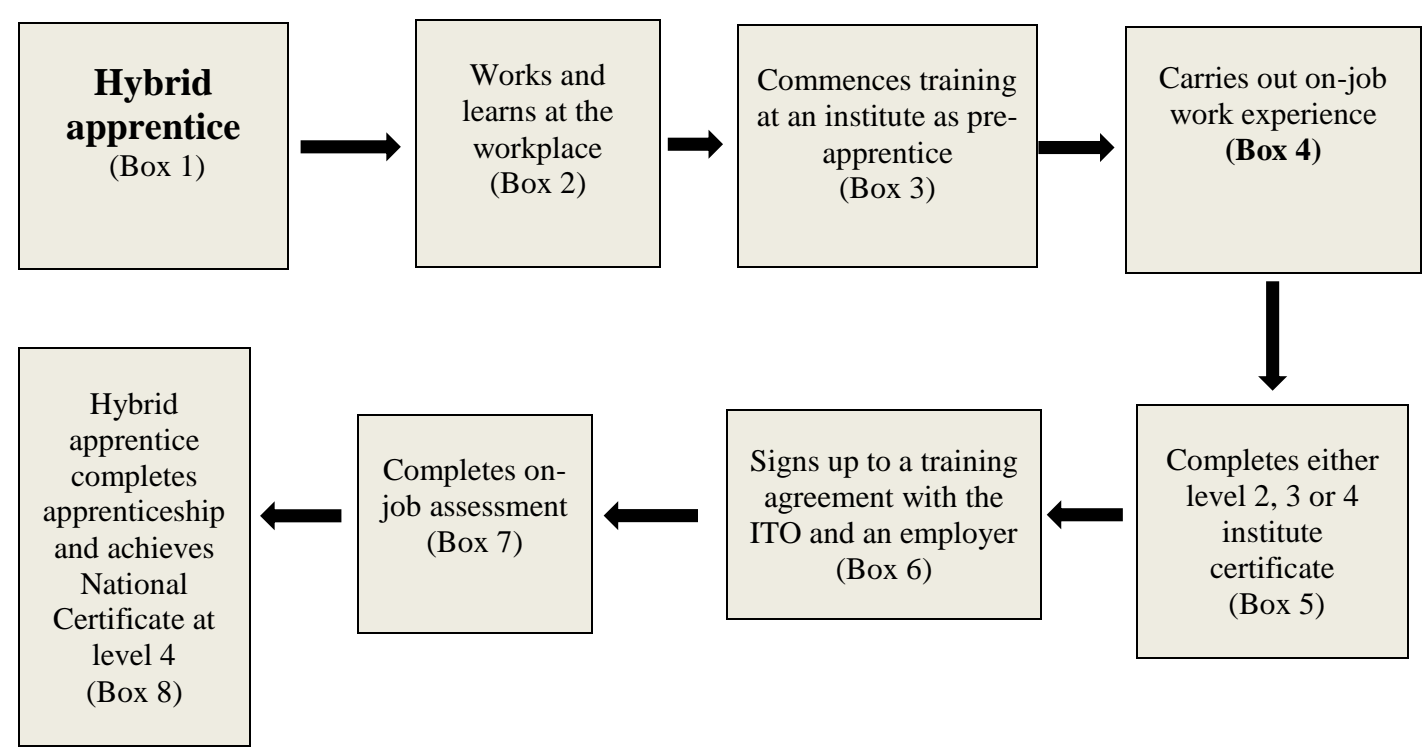

Figure 5.2. Modes of training: hybrid apprentice completing an apprenticeship

The interview data showed that employers were clearly supportive of pre-apprentice programs. The employers involved in the study had either taken on apprentices or had been involved with the students through work experience opportunities. Some had employed apprentices who had attended pre-apprentice training before commencing their apprenticeships, and subsequently some of the employers had employed apprentices who had not attended such courses. From their experience with either preapprentices or apprentices, the employers were in an important position to provide relative data regarding their professional views.

It was significant that a $3+2$ arrangement ( 3 days present on a pre-apprentice program and 2 days at the workplace) seemed to work particularly well for those students who had chosen to study and work in the hybrid mode of learning. A number of advantages that were evident for apprentices to continue this form of training and work arrangement were alluded to by the respondents. For instance, completing a preapprentice program over one year permitted an apprentice to achieve 120 credits towards their national qualification. This number of credits was substantially more than they could possibly achieve by studying on a part-time basis, particularly through distance learning and by attending a maximum of two weeks off-job at a block course.

Through attending an ITP and working as an apprentice, substantial knowledge and skills were achieved in conjunction with on-job practice. Through the hybrid 
arrangement it may well be argued that apprentices were gaining considerable training off-job and were also in a prime position to achieve on-job credits towards their full national certificate. As a result, an apprentice training and concurrently working in this manner had the potential to achieve their national qualification in a far quicker timeframe than would be possible by studying and working through a "New Zealand traditional apprenticeship" arrangement.

As indicated in the literature, pre-employment training courses in a New Zealand context are well supported in the current VET system, and the Tertiary Education Commission (2013) has shown that pre-apprenticeship training has increased in numbers of students choosing pre-apprentice options. The findings from the collected data in this study show that combining both modes of training as pre-apprentices and apprentices has certainly not been identified previously as an alternative method of training apprentices.

A model of training identified from this study indicated that a hybrid learning methodology was instrumental in improving apprenticeship training. The model of apprenticeships that may be compared to the "hybrid" option was the traditional German model of day release. However, the dual training system used in Germany would be termed a normal apprenticeship model while the New Zealand system currently uses short block courses and night class or distance learning models. A hybrid model has evolved, suggesting that the New Zealand system requires some modification to deliver a more effective form of apprenticeship system. 


\section{Chapter 6: Conclusion}

\subsection{Introduction}

In the final chapter I return to the original research question to consider:

What is the relative effectiveness of features of pre-apprenticeship and apprenticeship modes of delivery in engineering trades?

The chapter concludes with a discussion of the significance of the key research findings and considerations for future training, policy and further research. The main research question is addressed through the sub-questions with the following key points.

\subsection{Summary of Key Points in Relation to the Research Sub- questions}

The summary of key information from the findings indicates possible improvements to the quality of learning for pre-apprentices and apprentices in engineering trades. These are identified below relating to the research and sub-questions.

\subsubsection{Research sub-question 1: What are the benefits and challenges of different modes of training for engineering trade occupations in New Zealand?}

\subsubsection{Benefits for pre-apprentices and apprentices}

Work experience was deemed to be a valuable component of the program and a significant benefit for the students. Suggestions were given by students for future programs. They suggested that a placement coordinator should provide and arrange mandatory work placements for all students, and that the institutes should provide support in career skill development. Employers were more engaging and supported students attending the workplaces, and the lecturers were able to make important contacts when industry experience also became available to them. 
Students in the pre-apprentice programs stated that they benefited from attending the training courses as they gained a fuller understanding of the trade they would transition into. They indicated that they received full training towards their learning requirements to meet the needs of the workplace, and a majority of graduates expected that they would gain employment in a specific trade on completion of their programs.

Pre-apprentices also found there were substantial benefits associated with the program through undertaking practical learning activities. In particular, responses relating to the practical based projects were very constructive when students were required to work on projects as part of their practical learning. Using tools and equipment that had not been used previously was essential. This led the students into a "work readiness" mode, particularly as they experienced simulated work processes that were critical to succeed once at the workplace.

Apprentices received significant benefits from off-job training when engaged in integrated practical and knowledge activities. On their return to the workplace after their training courses, apprentices were able to put their training into practice and they showed definite improvements in real work practices. It was beneficial for some apprentices to have support from technicians at the workplace who had advanced knowledge which then helped them to complete specific jobs.

Benefits identified by apprentices who had transitioned from the pre-apprentice programs included being more motivated to learn, and being better prepared for the workplace compared to those who had not done pre-apprentice programs. Apprentices in the study identified that there was good practical based learning occurring in a number of workplaces. This supported the need for apprentices to gain practical learning experiences working with engineering tasks and the safe operation of hand tools and equipment. Another benefit for apprentices clearly included the fact that working and learning at the workplace meant being paid as opposed to learning full time and not receiving payment.

\subsubsection{Challenges for pre-apprentices and apprentices}

Work experience was a required part of the pre-apprentice training program; however, this component required students to find and arrange their own workplaces. As a result not all students were successful in finding workplaces, which made work experience 
inconsistent and a challenge. For some students, this proved difficult due to cultural differences and inexperience with promoting themselves to industry. There were other challenges for a number of pre-apprentices in terms of work experience including: working unsupervised in a work environment, needing to understand work ethics, presentation concerning appropriate work attire, ensuring awareness of the culture and work attitudes, and attending the workplace on time.

There were challenges in terms of timeframes available for some practical projects and a degree of frustration due to the length of time allowed for completion of projects at the ITP. There were difficulties for apprentices in both disciplines that included completion of on-job training and assessment requirements at the workplace. Employers were not always able to support sufficient training and there were concerns that the workplace was not conducive to a good learning environment.

\subsubsection{Research sub-question 2: How do different parties (employers, students, lecturers) view the different modes of training?}

Students obtained substantial skills through undertaking pre-apprenticeships. A significant benefit for pre-apprentices was the ability to gain a subsequent position as an apprentice at the workplace. Employers were more likely to employ preapprentices as they had recognised attributes to start an apprenticeship at year 2. These views were held by all participants in the study and they were confident that the preapprenticeship mode of training provided the prerequisite knowledge and practical skills in preparation for undertaking an apprenticeship in the workplace.

Lecturers were of the opinion that further improvements pertaining to on-job work experience for pre-apprentices were needed. These improvements would ensure that suitable arrangements could be made for workplace attendance in future preapprentice programs. Lecturers indicated that it was essential for pre-apprentices to be trained in using updated technologies situated in the workplace. These views were supported by employers when delivering training at the workplace. They also agreed that work plans must be instigated to ensure that training is arranged with technical staff in a position to train. A number of employers believed that the training occurring 
at the workplace was of a good standard and that apprentices were learning through doing work and were achieving worthwhile skills.

Lecturers indicated that completing the formative training in pre-apprentice programs was essential prior to commencing training at the workplace. Such training equipped pre-apprentices with sufficient knowledge and skills to apply what they had learnt to successful completion of tasks at the workplace. This viewpoint was also expressed by the majority of employers, with the exception of one, who was of the opinion that it was more beneficial for apprentices to go into the field prior to any training, to first undergo initial practical work and become established in a work setting.

Views from several employers supported the idea of additional training support being provided for the students. They believed it would be beneficial if industry and training institutes were to encourage improved working partnerships as a group of professional practitioners. Finally, workplaces needed to ensure that adequate training plans were available for apprentices to complete their training to national certificate level.

\subsubsection{Research sub-question 3: What learning and assessment practices contribute to high quality in the two modes of training?}

\subsubsection{Learning}

Respondents indicated that practical activities conducted at the Institute for both preapprentices and apprentices were very successful for both disciplines (automotive and refrigeration/air-conditioning/electrical). Through practical and project based assignments pertaining to both modes of training off-job, students were able to identify closely with the work practices carried out at the workplace. All three parties (students, lecturers and employers) acknowledged that project based learning was an effective method of training and that it provided an integrated method of formative and summative assessment for both apprentices and pre-apprentices, particularly in the refrigeration/air-conditioning /electrical trades. The lecturers acknowledged that the project work enabled the reinforcement of earlier prior knowledge and a clearer understanding of the skills needed in the workplace. 


\subsubsection{Assessment}

Current good practices identified in the findings included the way that assessment was organised and how it formatively checked how much the pre-apprentices understood of the topics studied. Some employers were unable to administer certain assessments at the workplace and they acknowledged a number of good practices to resolve this issue. For example, arrangements were made with alternative employers at other workplaces who had the ability to carry out specific on-job assessments to support the learning and assessment of apprentices. Good work practices were acknowledged to be occurring in some of the workplaces; in these instances apprentices were receiving superior support and mentoring from experienced technicians, which enabled successful completion of on-job assessment standards towards their qualifications. In doing so, apprentices also gained the ability to work with limited supervision to complete tasks in a commercial environment.

When engaged in project work, the students were able to complete assessments on an ongoing basis, which provided quality evidence of attainment for their total work from start to finish. Through continuous assessment practices, students were able to complete summative assessment effectively to meet the required standards. It was indicated that assessments would also be more beneficial to students with accurate timing of theory to the practical activities.

\subsubsection{Research sub-question 4: What improvements could be made to quality?}

The study findings indicated that pre-apprentice programs should be compulsory for all new apprentices who apply to become tradespeople. Benefits of these programs were cited as: essential knowledge and skills in preparation for industry, gaining onjob industry work experience or employment on-job, standardisation of preapprentices' training plans, and increased motivation and commitment. Respondents also recommended topics that should be included in the training programs, including: communication skills, work ethics, team work, customer service skills and selflearning. Another suggestion was providing assistance in career planning, for instance, how to source a job in industry. Lecturers and employers felt it was particularly important to improve the levels of students' people skills, as there were issues with a 
number of students within the program who lacked discipline, for instance, lateness to class and work experience.

Employers indicated that all students attending full-time pre-apprentice programs needed to attend work experience. There was also a need to find suitable workplaces for students to gain work experience. Employers were of the opinion that work experience should be a compulsory part of the program and organised by ITPs. In addition, an improved mechanism for selecting applicants for the workplace was recommended as a key requirement that needed to be instigated by the ITPs. Preapprentices indicated that they needed more time in the workplace for on-job training as it was currently insufficient.

Another recommendation was to combine theory with practical subjects through an integrated method of delivery. There was a demand by the students for increased practical training including projects, with the suggestion that theory needed to match the practical subjects instead of being taught in isolation. The lecturers determined that students would be more suitably equipped to be assessed on knowledge once the practical tasks were completed. There was also a need for more clarity and redevelopment of theory questions to ensure that for future students, theory assessment would be thoroughly understood. Investigating alternative holistic models of assessment, and introducing them where the theory and the practical assessment tasks were fully integrated, was also recommended.

The necessity for apprentices to take control of their own learning and on-job assessment was seen as an extension of the apprentices' regular work. Through this approach, work based learning informs learning where several tasks can be achieved concurrently, and apprentices are also able to judge their own process of assessment.

For improved off-job training to occur, the time allocated for apprentices to study needed restructuring to allow for adequate learning; it was indicated that the current timeframe given to complete training was too short. Improvements are also required for distance learning and night class training methods, as current systems do not provide adequate learning support for the apprentices.

Insufficient on-job training and assessment occurring in some workplaces also requires addressing to improve the chances of achieving best practice. Suggestions to 
improve quality training included additional industry support from ITOs for apprentices, and to improve ITO engagement with the apprentices to evaluate training opportunities in order to improve training plans.

\subsection{Considerations for Policy}

The hybrid learning model provided significant benefits for apprentices. They gained definite advantages through learning face-to-face with the lecturers at an ITP as well as undertaking ongoing learning and working at the workplace. In comparison to the apprenticeship training system, the training courses delivered through the preapprentice program were seen to be better structured and provided a superior integrated knowledge and practical base.

There is a need for policy makers to re-think the apprenticeship system. There must be recognition of the problems that are inherent in current modes of learning in apprenticeships to better meet training needs. The New Zealand Government's current policy provides a funding model where ITPs receive funding for pre-apprenticeship training only. In comparison, apprentices access their training through ITO funding once an agreement is signed and funding is allocated to the apprentice for traditional off-job training and distance learning. The current process encourages an either/or system where students studying full time can access part-time work while apprentices can only access part-time off-job training through the ITOs. The New Zealand Government should consider changing the funding arrangement for apprentices to access improved training opportunities. For instance, it would be more beneficial for apprentices to access the same funding levels as pre-apprentices so they can study for longer periods through off-job training.

The data showed that apprentices were finding that the current method of training was not effective. Both employers and apprentices were exploring alternative methods of learning to engage students in learning practices that would enhance the learning experience. The hybrid model was seen to be one approach to achieving enhanced learning opportunities.

Presently, for students and employers to overcome overlapping provisions, apprentices are employed on a full-time basis while pre-apprentices join the training 
program primarily on a yearly basis. For those students who decide to enter directly into the workplace from school, the current apprenticeship structure only provides for part-time learning to be undertaken through ineffective modes of learning. There is also a considerable timeframe required to complete a national qualification. As a consequence the literature shows that a number of apprentices become statistics due to attrition (Vaughan et al. 2012). Therefore, the New Zealand Government needs to address the current system and provide a suitable mechanism to provide for the hybrid model where definite advantages are apparent for both new apprentices and employers. Suggestions for re-considering the current apprenticeship system and moving to a more traditional dual system would achieve more effective outcomes for the apprentices.

In terms of producing proficient graduates for working in an engineering trade, it is evident that learners can access training from various entry points. In this study learners have originated from various occupations: ranging from school leavers with very little previous work experience, to adult learners who are already in employment and experienced. When accessing training through any of the alternative pathways, the data has indicated that learners can achieve results and be proficient at specific trades. This shows the importance of both off-job and on-job training opportunities in providing a wealth of knowledge and trade skills.

\subsection{Considerations for Future Research}

This research has raised some further interesting questions about the programs that are currently in place for both apprentices and pre-apprentices in New Zealand. There is the potential for further research to explore issues around work readiness and hybrid learning, and the types of training programs that are currently being offered. The data gathered during this study has also raised questions concerning the effectiveness of training completed through apprenticeships and particularly the lack of learning and on-job assessments occurring at the workplace. This section presents four issues arising from this study that need future research for pre-apprenticeship and apprenticeship systems in New Zealand. 


\subsubsection{Consideration 1: Completion of apprenticeships in an efficient timeframe}

The study has highlighted that there are still major issues related to apprentices achieving and completing their apprenticeships in the two engineering disciplines studied. The findings of this study have shown that there are significant factors that are contributing to this scenario. Therefore, further research needs to be done in this area to inform agencies such as the ITOs and government bodies about the problems facing the apprenticeship model as it currently stands.

\subsubsection{Consideration 2: On-job assessment achievement at the workplace}

The findings challenge ITOs about favouring increased learning and assessments at the workplace without adequate training plans in place and the availability of suitably qualified trainers and assessors to facilitate such training plans. A further study looking into on-job training and assessment would provide more information in this area.

\subsubsection{Consideration 3: Off-job training and assessment through pre-apprentice programs in preparation for the workplace}

The study confirmed the importance of offering pre-apprentice programs to provide new and adult learners with a significant program of learning knowledge and practical skills for the engineering trades. It also confirmed that pre-apprenticeship training is an important mode of learning recognised by employers as a useful form of training that readies students for employment. Further research into pre-apprenticeship training in New Zealand is definitely needed to inform debate on this mode of training.

\subsubsection{Consideration 4: Mature learners and what they bring to their training as apprentices and pre-apprentices}

A significant finding of the study showed that older learners, workers who had prior on-job work experiences, and some learners who continued their work part time whilst studying, came into the learning program with a considerable knowledge of work ethics. More research needs to be done in this area to better inform potential 
employers when they make decisions pertaining to work experience and potential new employment opportunities for graduates of the training programs.

\subsection{Conclusion}

This research has examined - through case studies with pre-apprentices and apprentices, and interviews with lecturers and employers-differences in skills, knowledge and assessment whilst learning on- and off-job. The findings have been examined against a range of literature; however, literature surrounding preapprenticeship and apprenticeship learning in New Zealand was found to be limited, and further research needs to be conducted to address the lack of research in this area. It is hoped that this study has made a contribution to filling the research gap.

A major contribution of the research to the contemporary literature on New Zealand's apprenticeship and the international VET arena was the discovery of a new breed of apprentices. Through this new phenomenon a significant contribution to current knowledge was extended through the discovery of hybrid learners. Hybrid learners are recognised in the workplace and begin an apprenticeship while simultaneously attending training programs as pre-apprentices. Through the hybrid strategy apprentices were able to achieve considerable training off-job and on-job credits towards their full national certificate, and through the hybrid mode of learning an entire new connotation of apprenticeship training was initiated.

The study findings identified that graduates from the pre-apprentice programs were actively sought after by employers for recruitment, and employed straight into apprenticeships. As a result of thorough practical project based coursework pertaining to both modes of training off-job, students were able to identify closely with the work practices carried out at the workplace. Graduates were able to reach a position of work readiness through the pre-apprentice programs by experiencing simulated work processes and by actively engaging at the workplace on work experience.

The study findings have also identified a number of significant concerns, including difficulties for apprentices in achieving on-job learning and assessment requirements at the workplace. In terms of the teaching and off-job training for pre-apprentices, 
important differences between the two disciplines were found concerning the various approaches to learning occurring in pre-apprenticeship training.

Implications for improved programs of study have been identified, including the need for the New Zealand Government to consider the needs of learners undertaking trade training. The data shows that the current method of training needs improvement. Four considerations for future research to improve the training systems and to further examine other findings of the study have been suggested. The importance of providing quality pre-apprenticeship and apprenticeship training in New Zealand is critical to ensure that businesses can be confident they are employing quality tradespeople and to ensure the best outcomes for pre-apprentices and apprentices. 


\section{References}

Aarkrog, V. (2005). In the workplace and the significance of school-based education: A study of learning in a Danish vocational education and training program. International Journal of Lifelong Education, 24(2), 137-147.

Australian National Training Authority (ANTA). (1997). The report of the ANTA Board on the implementation of New Apprenticeships (including User Choice). Brisbane, Australia: Author.

Bewick, T. (2014). How do you create apprenticeships out of thin air? London, UK: International Skills Standards Organisation. Retrieved from http://www.urban.org/sites/default/files/final-tom-bewick-ppt-09-06-14.pdf

Billett, S. (2001, November). Participation and continuity at work: A critique of current workplace learning discourses. Paper presented at the Joint Network/SKOPE/TLRP International workshop, Context, power and perspective: Confronting the Challenges to Improving Attainment in Learning at Work, Sunley Management Centre, University College of Northampton, UK.

Billett, S. (2009). Realising the educational worth of integrating work experiences in higher education. Studies in Higher Education, 34(7), 827-843.

Bogdan, R. C., \& Biklen, S. K. (1998). Qualitative research in education: An introduction to theory and methods (3rd ed.). Needham Heights, MA: Allyn \& Bacon.

Booth, R. \& Parkinson, S. (1996) Work-based learning: a new role for teachers and trainers? Training Agenda: A Journal of Vocational Education and Training, 4, pp. 3-5.

Bowers-Brown, T., \& Berry, D. (2005). Building pathways: Apprenticeships as a route to higher education. Education \& Training, 47(4/5), 270-282.

Bragg, D. D. (2000). Tech prep: Winning ideas, challenging practices. Techniques: Connecting Education and Careers, 75(4), 14-17.

Brown, B. L. (2003). CTE and work-based learning. Columbus, OH: ERIC Clearinghouse on Adult Career and Vocational Education (ERIC Document Reproduction Service No. ED 482334).

Brown, M. (2015). A history of apprenticeship and trade training in Victoria, Australia. In E. Smith, P. Gonon, \& A. Foley (Eds.), Architectures for apprenticeships: Achieving economic and social goals (pp. 33-38). Melbourne, Australia: Australian Scholarly Publishing.

Callan, V. (2008). Accelerated apprenticeships: Apprentice, employer and teaching staff perception. Adelaide, Australia: National Centre for Vocational Education Research.

Chan, S. (2011a). Belonging to a workplace, becoming and being a baker: The role and processes of apprenticeship (Unpublished doctoral dissertation). Griffith University, Australia.

Chan, S, (2011b). Learning practical workplace-based judgement through using cognitive apprenticeship and occupational identity formation models. Foreign Language Teaching and Research Press, Beijing. 
Chan, S. (2012). Perspectives of new trades tutors: Boundary crossing between vocational identities. Asia Pacific Journal of Teacher Education, 40(4), 409-421.

Chan, S. (2013a). Learning a trade: Becoming a trades person through apprenticeship. Wellington, NZ: Ako Aotearoa-National Centre for Tertiary Teaching Excellence. Retrieved from https://akoaotearoa.ac.nz/ako-hub/akoaotearoa-southern-hub/resources/pages/learning-trade-becoming-trades-personthrough-apprenticeship

Chan, S. (2013b). Learning through apprenticeship: Belonging to a workplace, becoming and being. Vocations and Learning, 3(6), 367-383.

Choy, S., Bowman, K., Billett, S., Wignall, L., \& Haukka, S. (2008). Effective models of employment based training. Adelaide, Australia: National Centre for Vocational Education Research.

Choy, S, Haukka, S, Billet, S, Bowman, K \& Wignall, L. (2007). Emerging models of employment based training: untangling the drivers and identifying key features of effective models. Proceedings of the 10th Annual Conference of the Australian VET Research Association (AVETRA). Retrieved from www.avetra.org.au

Competenz. (2016). Information. Retrieved from http://www.competenz.org.nz/industries/engineering/refrigeration-and-airconditioning

Connor, H. (2005). Work based learning: A consultation, London, UK: Council for Industry and Higher Education. Retrieved from http://www.cihe-uk.com/docs/

Cornford, I. (1996). The defining attributes of "skill" and "skilled performance": Some implications for teaching, learning and program development. Australian and New Zealand Journal of Vocational Education Research, 4(2), 1-25.

Costin, G., \& Nichols, L. (2007). A limited enquiry into workplace delivery and assessment: A symposia in two parts: Researching good practice in workplace delivery of qualifications.TAFE NSW Riverina Institute Primary Industries Centre. Friday 26th October 2007.

Crawford, R. (2016). New Zealand Productivity Commission Research Note 2016/1: History of tertiary education reforms in New Zealand. Wellington, NZ: New Zealand Productivity Commission. Retrieved from http://www.productivity.govt.nz/sites/default/files/nzpc-rn-2016-1-history-oftertiary-education-reforms.pdf

Creswell, J. W., \& Creswell, J. W. (2007). Qualitative inquiry \& research design: Choosing among five approaches. Thousand Oaks, CA: Sage.

Crotty, M. (1998). Introduction: The research process. In The Foundations of Social Research (pp. 1-17). Sydney, Australia: Allen \& Unwin; Sage.

Cullen, J., Hadjivassiliou, K., Hamilton, E., Kelleher, J., Sommerlad, E., \& Stern, E. (2002). Review of current pedagogic research and practice in the fields of postcompulsory education and lifelong learning (Final report submitted to the Economic and Social Research Council). London, UK: The Tavistock Institute.

Deissinger, T., Smith, E., \& Pickersgill, R. (2006). Models of full-time and part-time vocational training for school-leavers: A comparison between Germany and Australia. International Journal of Training Research, 4(1), 30-50. 
Denscombe, M. (2010). The good research guide: For small-scale social research projects. Maidenhead, UK: McGraw-Hill Education.

Department of Education and Training Australia, (2016). Vocational education and training reform. Retrieved from https://www.aisc.net.au/search/site/Vocational\%20Education\%20and\%20Training $\% 20$ Reform.

Dougherty, I. (1999). Bricklayers and mortarboards: A history of New Zealand polytechnics and institutes of technology. Palmerston North, NZ: Dunmore Press.

Dumbrell, T. (2003). Pathways to apprenticeship. Adelaide, Australia: National Centre for Vocational Education Research.

Dumbrell, T., \& Smith, E. (2007). Pre-apprenticeships in three key trades. Adelaide, Australia: National Centre for Vocational Education Research.

Electrotechnology \& Telecommunications Industry Training Organisation. (ETITO). (2006). Industrial measurement and control research findings. Auckland, NZ.

Retrieved from https://akoaotearoa.ac.nz/research-register/list/industrialmeasurement-and-control-research-findings

Favero, J. (2003). "Quality" training: Challenges for teachers of workplace training for trainees and apprentices' in The sixth Australian VET Research Association Conference: The changing face of VET. Nowra, Australia: Australian Vocational Education and Training Research Association.

Fossey, E., Harvey, C., McDermott, F., \& Davidson, L. (2002). Understanding and evaluating qualitative research*. Australian \& New Zealand Journal Of Psychiatry, 36(6), 717-732. doi:10.1046/j.1440-1614.2002.01100.x

Fuller, A., \& Unwin, L. (1998). Reconceptualising apprenticeship: Exploring the relationship between work and learning. Journal of Vocational Education \& Training, 50(2), 153-173.

Fuller, A., \& Unwin, L. (2002). Developing pedagogies for the contemporary workplace. In K. Evans, P. Hodkinson, \& L. Unwin (Eds.), Working to learning: Transforming learning in the workplace (pp. 95-111). London, UK: Kogan Page.

Fuller, A., \& Unwin, L. (2010). The NAS toolkit: Expansive apprenticeships: A guide for employers, training providers and colleges of further education. London, UK: National Apprenticeship Service.

Fuller, A., \& Unwin, L. (2011). Towards expansive apprenticeships. A commentary by the Teaching and Learning Research Programme. London, UK: Economic and Social Research Council. Retrieved from http://learning.gov.wales/docs/learningwales/publications/140721-towardsexpansive-apprenticeships-en.pdf

Green, N., Hipkins., C, Williams P., \& Murdoch, C. (2003). A brief history of government funding for industry training 1989-2002. Wellington, NZ: The Industry Training Federation.

Harbourne, D. (2014). New Zealand industry training and apprenticeships report: May 2014. Retrieved from http://www.edge.co.uk/media/133444/new_zealand_industry_training_and_apprent iceships_report_may_2014.pdf 
Harris, R., \& Simons, M. (2005). Exploring the notion of retention in apprenticeships. Education + Training, 47(4/5), 350-65.

Harris, R., Simons, M., \& Bone, J. (2006). Mix or match? New apprentices' learning styles and trainers' preferences for training in workplaces. Adelaide, Australia: National Centre for Vocational Education Research.

Hoy-Mack, P. (2004). Workplace assessment in New Zealand: Stated intentions and realisations. International Journal of Training Research, 3(1), 79-95.

Industry Training Federation of New Zealand. (2007). Learner perceptions of industry training, Wellington, NZ: Author. Retrieved from http://hdl.voced.edu.au/10707/22156

Industry Training Federation of New Zealand. (2014). Delivering value: the contribution of ITOs to NZ vocational education and training. Wellington, NZ: Author. Retrieved from http://www.itf.org.nz/files/3514/2593/0968/DeliveringValue-2014-v2-print-ready1.pdf

Karmel, T. (2006). Older workers in apprenticeships and traineeships. Adelaide, Australia: National Centre for Vocational Education Research.

King, M. (1985). Being Pākehā: An encounter with New Zealand and Māori renaissance. Auckland, NZ: Hodder and Stoughton.

Kitzinger, J. (1994).The methodology of focus groups: The importance of interaction between research participants. Sociology of Health \& Illness, 16(1), 103-121.

Knight, A., \& Nestor, M. (Eds.). (2001). A glossary of Australian vocational education and training terms [superseded version]. Retrieved from http://www.voced.edu.au/content/ngv\%3A8391

Krueger, R. (1994). Focus groups: A practical guide for applied research (2nd ed.). Thousand Oaks, CA: Sage.

LaRocque, N. (2007). Skill development and skill and shortages in New Zealand. Education Forum. Retrieved from https://nzinitiative.org.nz/insights/reports/skilldevelopment-and-skill-shortages-in-new-zealand/

Lave, J., \& Wenger, E. (1991). Situated learning: Legitimate peripheral participation. Cambridge, UK: Cambridge University Press.

Lucas, B., \& Spencer, E. (2015). Remaking apprenticeships: Powerful learning for work and life. London, UK: City and Guilds. Retrieved from http://www.cityandguilds.com/search?n=0\&q=remaking+apprentices\&s=relevance

Maurice-Takerei, L. (2015). Constructing an identity: The work and world of polytechnic trade tutors in New Zealand (A thesis submitted in partial fulfilment of the requirements for the degree of Doctor of Education). University of Auckland, NZ. Retrieved from https://researchspace.auckland.ac.nz/handle/2292/25652?show=full

Merriam, S. B. (1998). Case study research in education: A qualitative approach. San Francisco, CA: Jossey-Bass.

Ministry of Education. (2015). History of Industry Training. Retrieved from https://www.education.govt.nz/assets/Documents/Ministry/consultations/Reviewof-industry-training/HistoryOfIndustryTrainingFINAL.pdf 
Ministry of Education. (2016). Profile \& trends 2015: New Zealand's annual tertiary education enrolments (Part 1 of 6). Tertiary Sector Performance Analysis, Ministry of Education. Retrieved from http://www.educationcounts.govt.nz/_data/assets/pdf_file/0010/172495/Profileand-Trends-2015-NZs-Annual-Tertiary-Education-Enrolments-Part-1-of-6.pdf

Misko, J. (2006). Vocational education and training in Australia, the United Kingdom and Germany. Adelaide, Australia: National Centre for Vocational Education Research.

Mitchell, J., Chappell, C., Bateman, A., \& Roy, S. (2006). Quality is the key: Critical issues in teaching, learning and assessment in vocational education and training. Adelaide, Australia: National Centre for Vocational Education Research.

Mitchell, J., Henry, J., \& Young, S. (2001). Workbased learning in the contemporary Australian VET sector: A reappraisal, in 10th National Vocational Education and Training Research Conference. Adelaide, Australia: National Centre for Vocational Education Research.

Motor Industry Training Organisation. (2016). Resources. Retrieved from https://resources.mito.org.nz/

Murray, N. (2001). A history of apprenticeship in New Zealand (Thesis submitted in partial fulfilment of the requirements for the Degree of Master of Social Science). Lincoln University, UK. Retrieved from https://researcharchive.lincoln.ac.nz/handle/10182/1599

Neuman, W. L. (2003). Social research methods: Qualitative and quantitative approaches (5th ed). Boston, MA: Allyn and Bacon.

New Zealand Government. (2005-2016). Te Ara: The Encyclopedia is the complete guide to our peoples environment, history, culture and society. Retrieved from http://www.teara.gov.nz/en/copyright

New Zealand Industry Training Amendment Act. (2002). Industry Training Amendment Bill. Government Bill. Retrieved from http://www.nzlii.org/nz/legis/hist_bill/itab20021803potterb1802813/

New Zealand Ministry of Education. (1992). Industry Training and Apprenticeships Act 1992 Part 1 (New Zealand). Wellington, NZ: Author. Retrieved from http://www.legislation.govt.nz/act/public/1992/0055/latest/DLM266246.html

New Zealand Ministry of Education. (2012). Industry training review: Results of the employer interviews and survey (New Zealand Ministry of Education review of industry training). Wellington, NZ: Author. Retrieved from https://education.govt.nz/assets/Documents/Ministry/consultations/Review-ofindustry-training/ResultsOfEmployerInterviewsSurvey.pdf

New Zealand Ministry of Education. (2015). Annual report. Wellington, NZ: Author. Retrieved from https://education.govt.nz/assets/Documents/Ministry/Publications/AnnualReports/MOE-Annual-Report-2015.pdf

New Zealand Ministry of Education. (2016). New Zealand education system overview. Wellington, NZ: Author. Retrieved from http://minedu.cwp.govt.nz/assets/Uploads/NZ-Education-System-Overviewpublication-web-format.pdf 
New Zealand Qualifications Authority (NZQA). (2010). Targeted review qualifications. Retrieved from http://www.nzqa.govt.nz/studying-in-newzealand/nzqf/targeted-review-of-qualifications/

New Zealand Qualification Framework (NZQF). (1989) New Zealand Framework. Wellington, NZ: Retrieved from http://www.nzqa.govt.nz/assets/Studying-inNZ/New-Zealand-Qualification-Framework/requirements-nzqf.pdf

New Zealand Qualification Framework (NZQF). (2016). Directory of Assessment Standards. Wellington, NZ: Author. Retrieved from http://www.nzqa.govt.nz/qualifications-standards/standards/

Patton, M. Q. (2002). Qualitative research and evaluation methods (3rd ed.). Thousand Oaks, CA: Sage.

Pells, S. (2006). Skills and training in the building and construction industry. Wellington, NZ: New Zealand Institute of Economic Research. Retrieved from https://akoaotearoa.ac.nz/community/ako-aotearoa-suggestedresources/resources/pages/skills-and-training-building-and-construc

Pollock, K. (2012). “Tertiary education-Polytechnics before 1990”, Te Ara: The Encyclopedia of New Zealand. Retrieved from http://www.TeAra.govt.nz/en/tertiary-education/page-2

Ray, J. (2001). Apprenticeship in Australia: A concise history. In N. Smart (Ed.), Australian apprenticeships: Research readings (pp. 15-41). Adelaide, Australia: National Centre for Vocational Education Research, Adelaide.

ServiceIQ Industry Training Organisation. (2017). What is an ITO? Retrieved from http://www.serviceiq.org.nz

Silverman, D. (2006). Interpreting qualitative data. (3rd ed.). London, UK: Sage.

Skill New Zealand. (2001). Modern apprenticeships news. Wellington, NZ: Author.

Smith, E., Comyn, P., Brennan Kemmis, R., \& Smith, A. (2009). High quality traineeships: Identifying what works. Adelaide, Australia: National Centre for Vocational Education Research.

Smith, E., \& Harris, R. (2000). Work placements in vocational education and training courses: Evidence from the cross-sectoral literature. Adelaide: Australia: National Centre for Vocational Education Research.

Smith, L. (2000). Issues impacting on the quality of assessment in vocational education and training in Queensland. Brisbane, Australia: Department of Employment Training and Industrial Relations.

Smith, R., \& Betts, M. (2000). Learning as partners: Realising the potential of workbased learning. Journal of Vocational Education and Training, 52(4), 589-604.

Stake, R. E. (2000). Case studies. In N. K. Denzin, \& Y. S. Lincoln (Eds.), Handbook of qualitative research (2nd ed., pp. 134-164). Thousand Oaks, CA: Sage.

Statistics New Zealand. (2013). Population clock. Retrieved from http://stats.govt.nz/tools_and_services/population_clock.aspx

Statistics New Zealand. (2017). Population clock. Retrieved from http://stats.govt.nz/tools_and_services/population_clock.aspx 
Stenstrom, M-L., \& Laine, K. (2007). Quality assurance and practice-oriented assessment in European vocational education and training. Paper presented at the Vocational Education and Training Network Conference, Ghent, Belgium.

Taylor, S. (2001). Getting employers involved: Improving work-based learning through employer links: Report and good practice guidelines. London, UK: Learning and Skills Development Agency.

Teddlie, C., \& Tashakkori, A. (2009). Foundations of mixed methods research: Integrating quantitative and qualitative approaches in the social and behavioural sciences. Thousand Oaks, CA: Sage.

Tertiary Education Commission. (2013). 2013 performance: Tertiary enrolments. Retrieved from http://pr2013.publications.tec.govt.nz/2013+Performance/Tertiary+enrolments

Tertiary Education Commission. (2014). Directory of ITOs. Retrieved from http://www.tec.govt.nz/teo/working-with-teos/itos/directory/

Tertiary Education Commission. ( 2015). Governance of ITOs. Retrieved from http://www.tec.govt.nz/teo/working-with-teos/itos/governance/

Tertiary Education Commission. (2016). The code of good practice for New Zealand apprenticeships. Retrieved from: http://www.tec.govt.nz/assets/Publications-andothers/The-code-of-good-practice-for-new-zealand-apprenticeships.pdf

Timma, H. (2007, April). Learning, training and assessing on-the-job: What do workers think? Paper presented at Evolution, revolution or status quo? VET in new contexts. 10th Annual Conference of the Australian Vocational Education and Training Research Association (AVETRA), Victoria University, Melbourne, Australia.

Vaughan, K. (2008). Workplace learning: A literature review. Wellington, NZ: New Zealand Council for Educational Research.

Vaughan, K. (2012). The integration of work and learning in New Zealand. Wellington, NZ: New Zealand Council for Educational Research.

Vaughan, K., \& Cameron, M. (2009). Assessment of learning in the workplace: A background paper. Wellington, NZ: Industry Training Federation of New Zealand.

Vaughan, K., \& Cameron, M. (2010). ITO workplace assessment structures and systems: survey and focus group findings: Report prepared for the Industry Training Federation Research Network. Wellington, NZ: National Centre for Tertiary Teaching Excellence. Retrieved from http://akoaotearoa.ac.nz/download/ng/file/group-1656/n3937-ito-workplaceassessment-structures-and-systems---survey-and-focus-group-findings.pdf

Vaughan, K., Gardiner, B., \& Eyre, J. (2012). A transformational system for on-job assessment in the building and construction industries. Wellington, NZ: Ako Aotearoa (National Centre for Tertiary Teaching Excellence). Retrieved from https://akoaotearoa.ac.nz/bci-assessment

Vaughan, K., O, Neil, P., \& Cameron, M. (2011). Successful workplace learning: How learning happens at work. Wellington, NZ: Industry Training Federation of New Zealand. 
Wareham, A. (2012). Evaluating the effectiveness of plumbing and gas-fitting pretrade programs in New Zealand. The Value and Voice of VET Research for individuals, industry, community and the nation. Paper presented at the 15th Australian Vocational Education and Training Research Association Conference, Melbourne, Australia. Retrieved from http://avetra.org.au/wpcontent/uploads/2012/05/Anthoney-Wareham-Paper-No.-29-Final-Doc.-MAY2012.pdf

Winch, C., \& Clarke, L. (2003). "Front-loaded" vocational education versus lifelong learning: A critique of current UK government policy. Oxford Review of Education, 29(2), 239-252.

Wong, L. P. (2008). Focus group discussion: A tool for health and medical research. Singapore Medical Education Journal, 49(3), 256-261.

Yin, R. K. (1984). Case study research: Design and methods. Newbury Park, CA: Sage.

Yin, R. K. (1994). Case study research: Design and methods (2nd ed.). Thousand Oaks, CA: Sage. 


\section{Appendix A: Ethics Approval}

\section{Approval}

University of Ballarat

Human Research Ethics Committee

\begin{tabular}{|l|l|}
\hline Principal Researcher: & Erica Smith \\
\hline Student/Other Researcher/s: & James Cannan \\
\hline School/Section: & Education \& Arts \\
\hline Project Number: & A11-080 \\
\hline Project Title: & $\begin{array}{l}\text { Learning through practice: A study of work-based } \\
\text { learning as part of VET programs in New Zealand }\end{array}$ \\
\hline For the period: & $23 / 8 / 2011$ to $31 / 3 / 2013$ \\
\hline
\end{tabular}

NB: $\quad$ Please submit evidence of approval from Manukau Institute of Technology when received.

Please quote the Project No. in all correspondence regarding this application.

\section{REPORTS TO HREC:}

An annual report for this project must be submitted to the Ethics Officer on:

\section{August 2012}

http://guerin.ballarat.edu.au/ard/ubresearch/hdrs/ethics/humanethics/docs/annual re port.doc

A final report for this project must be submitted to the Ethics Officer on:

30 April 2013

http://guerin.ballarat.edu.au/ard/ubresearch/hdrs/ethics/humanethics/docs/final repor $\underline{\text { t.doc }}$

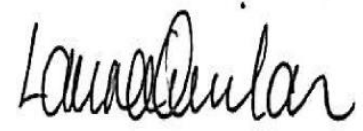

\section{Ethics Officer}

23 August 2011 


\section{CONDITIONS OF APPROVAL}

1. The project must be conducted in accordance with the approved application, including any conditions and amendments that have been approved. You must comply with all of the conditions imposed by the HREC, and any subsequent conditions that the HREC may require.

2. You must report immediately anything which might affect ethical acceptance of your project, including:

- Adverse effects on participants;

- Significant unforeseen events;

- Other matters that might affect continued ethical acceptability of the project.

3. Where approval has been given subject to the submission of copies of documents such as letters of support or approvals from third parties, these must be provided to the Ethics Office before the research may commence at each relevant location.

4. Proposed changes or amendments to the research must be applied for, using a 'Request for Amendments' form, and approved by the HREC before these may be implemented.

5. If an extension is required beyond the approved end date of the project, a 'Request for Extension' should be submitted, allowing sufficient time for its consideration by the committee. Extensions cannot be granted retrospectively.

6. If changes are to be made to the project's personnel, a 'Changes to Personnel' form should be submitted for approval.

7. An 'Annual Report' must be provided by the due date specified each year for the project to have continuing approval.

8. A 'Final Report' must be provided at the conclusion of the project.

9. If, for any reason, the project does not proceed or is discontinued, you must advise the committee in writing, using a 'Final Report' form.

10. You must advise the HREC immediately, in writing, if any complaint is made about the conduct of the project. 
11. You must notify the Ethics Office of any changes in contact details including address, phone number and email address.

12. The HREC may conduct random audits and / or require additional reports concerning the research project.

Failure to comply with the National Statement on Ethical Conduct in Human Research (2007) and with the conditions of approval will result in suspension or withdrawal of approval. 
From: Willem Fourie [mailto:willem.fourie@manukau.ac.nz]

Sent: Wednesday, 7 September 2011 4:10 p.m.

To: James Cannan

Cc: Helen Anderson; Brenda Theart a

Subject: Re: [Fwd: FW: Profesional Doctorate]

Hi James

I have reviewed your ethics application for your professional doctoral research with the University of Ballarat. I am satisfied that there are no ethical risks in relation to MIT staff or students. You have provided a consent form for focus groups however, I did not see a consent form for the individual interviews with 8 lecturers. Please provide a consent form that specifically covers the individual interviews with lecturers. Please include in the participant information sheet that the decision to participate will in no way affect the students grades and in the case of staff their continued employment. I would also like to have written confirmation from you that there is no unequal relationship between you as Head of a School and the 8 lecturers you wish to interview.

To speed up the process, you are welcome to address the above points in the meanwhile. Brenda Theart will provide you with a letter outlining the above conditions. Thus, in your response please submit the documents along with a cover letter of what you have done Once we have this I will recommend approval so that you can progress and we will table it at Academic Board

Please contact me if this is not clear

Kind regards

Willem Fourie .

\section{Willem Fourie [willem.fourie@manukau.ac.nz]}

\section{Attachments:}

RE: [Fwd: FW: Profesional Doc...

Inbox

Friday, 30 September 2011 9:38 a.m.

Hi Brenda

I would like to confirm that James Cannan has met the requirements for ethics approval. Please keep a record of the attached documents and place his project on the report for next academic board.

Thanks

Willem 


\section{MEMORANDUM}

MANUKAU

INSTITUTE OF

TECHNOLOGY

Te Whare Tokiurc

o Manukau

TO: Willem Fourie

Ethics Committee

FROM: James Cannan

DATE: $12-9-2011$

SUBJECT: Learning through Practice: A study of work-based learning as part of VET programs in New Zealand

Dear Willem,

I would like to advise that I have completed the requirements as requested in order to complete the approval process required by the Ethics committee. I have attached a consent form that specifically covers the individual interviews with lecturers, and under the plain language information statement I have added the statement "decisions to participate will in no way affect the students grades, and in the case of staff their continued employment" in paragraph two under the explanation of the project.

I would also like to advise that there will be no unequal relationships that will occur between me as Head of School and the 8 lecturers that I wish to interview.

Regards

James

James Cannan

Head of School

Mechanical Engineering and Trades

Manukau Institute of Technology

Private Bag 94006

Manukau 2241

9688076

0275688076 
12 September 2011

MANUKAU

INSTITUTE OF

TECHNOLOGY

Te Whare Tokiuro

o Manukau

James Cannan

Faculty of Engineering and Trades

Manukau Institute of Technology

Head of School - Mechanical Engineering \& Trades

P.O. Box 663 Ballarat VIC 3353

Dear James Cannan

Your application for ethical approval for:

E11/EXP/11_Learning through Practice: A study of work-based learning as part of VET programs in New Zealand (MEC/11/EXP/036) E Smith \& J Cannan

The MIT Ethics Committee has reviewed your ethics application for your professional doctoral research with the University of Ballarat and would like to recommend approval subject to:

- A consent form for the individual interviews with 8 lecturers be provided.

- The participant information sheet must include a statement that the decision to participate will not affect the students' grades and in the case of staff their continued employment.

- Written confirmation that there is no unequal relationship between you as Head of a School and the 8 lecturers you wish to interview.

Thank you for your cooperation and I wish you all the best with your studies Yours sincerely

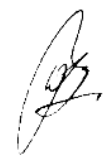

Dr Willem Fourie

Chair- Ethics Subcommittee

Newbury Street, Otara | Private Bag 94006, South Auckland Mail Centre, Manukau 2241, Auckland, New Zealand TELEPHONE 099688000 | FACSIMILE 099688701 | WEBSITE www.manukau.ac.nz 


\section{Attachments:}

RE: [Fwd: FW: Profesional Doc...

Inbox

Friday, 30 September 2011 9:38 a.m.

Hi Brenda

I would like to confirm that James Cannan has met the requirements for ethics approval. Please keep a record of the attached documents and place his project on the report for next academic board.

Thanks

Willem

\section{AB10/10 ETHICS SUB-COMMITTEE REPORT TO 14 OCTOBER 2011 MEETING OF THE ACADEMIC BOARD}

Purpose

To provide the Academic Board the Ethics Sub-Committee 20 September 2011 meeting report.

\section{Commentary}

Applications discussed for Academic Board consideration include:

E11/EXP/10:

E11/EXP/11: $\quad$ Learning through Practice: A study of work-based learning as part of VET programmes in New Zealand

(MEC/11/EXP/036) E Smith \& J Cannan

\section{E11/EXP/12:}

E08/FOB/10:

\section{Recommendation}

- That the Academic Board approves the research projects E11/EXP/10, E11/EXP/11, $\mathrm{E} 11 / \mathrm{EXP} / 12$, and E08/FOB/10.

- That the Academic Board receive the Ethics Sub-Committee report to the 14 October 2011 meeting of the Academic Board.

Responsible for Report Recommended by

Brenda Theart

Sub-Committee Secretary
Willem Fourie

Sub-Committee Chair 


\section{Manukau Institute of Technology \\ Report of 20 September \\ 2011 Ethics Committee \\ to the 14 October 2011 \\ Meeting of Academic Board}

\section{EXPEDITED APPLICATIONS}

\begin{tabular}{|l|l|}
\hline E11/EXP/10 & \\
\hline E11/EXP/11 & $\begin{array}{l}\text { Learning through Practice: A study of work-based learning as part } \\
\text { of VET }\end{array}$ \\
\hline E11/EXP/12 & \\
\hline
\end{tabular}

The committee recommends that Academic Board approves this research project.

\section{INTERNAL APPLICATIONS}

E08/FOB/10

The committee recommends that Academic Board approves this research project.

\section{GENERAL BUSINESS}

\section{DISCUSSION}

None

Dr Willem Fourie (Chair)

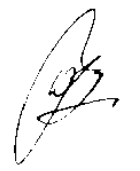

5 October 2011 


\section{Appendix B: Plain Language Information Statement}

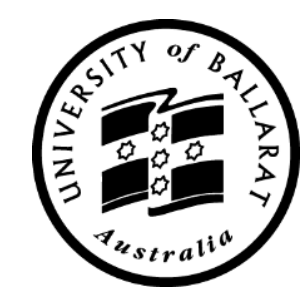

UNIVERSITY OF BALLARAT

\section{PLAIN LANGUAGE INFORMATION STATEMENT}

PROJECT TITLE: Learning through Practice: A study of work-based learning as part of VET programs in New Zealand.

RESEARCHERS:

Principal Researcher: Professor Erica Smith, University of Ballarat.

Names of other Senior and Associated Researchers: James Cannan, Manukau Institute of Technology.

\section{EXPLANATION OF PROJECT:}

In this research we seek to determine how alternative practice based models of learning support the initial preparation and actual practice that is gained at the workplace when delivering practice focused learning in Vocational Education and Training (VET) courses in New Zealand, and to identify potential issues pertaining to delivery and assessment as a result of the integration of course work and workplace learning. The research will involve a ca se study approach on 'Learning through Practice'. The primary focus of the study will be to investigate the benefits gained for students, lecturers and industry when using practice-based learning models delivering programs of study at certificate level in vocational education and training (VET) at a New Zealand tertiary institution

We invite you to participate in this important project. You are under no obligation to take part and can withdraw at any time before data is collated without giving any reasons. You can choose not to answer particular questions in your questionnaire, focus group or interview. Participants can request a copy of the transcript or notes if they like, and may remove anything that they decide they do not want to stand. Your interview or focus group will last for between 30 and 60 minutes.

The interviews and focus group interviews will provide unique and new insights about practice based learning styles. The sorts of questions that will be asked during the research will pertain to the delivery of practice-based learning and assessment relative to learning at the workplace and away from the workplace. Questions asked will include the following topics: methods and structures for learning, learning mechanisms, delivery of theory methods, interrelationship between practical and theory. The analysis and synthesis of findings will be documented in a report. All data, findings and discussion will protect anonymity and confidentiality. The final report will be made available to all participants.

If anything upsets you during the research you may wish to contact Lifeline (http://www.lifeline.co.nz/ telephone counselling service.0800543354).

If you have any concerns, or would like further information, please contact the principal researcher as listed below. Thank you for your assistance, which is greatly appreciated.

If you have any questions, or you would like further information regarding the project entitled 'Learning through Practice: A study of work-based learning as part of VET programs in New Zealand. Please contact the Researcher James Cannan on 095687305 or email james.cannan@manukau.ac.nz

Should you (i.e. the participant) have any concerns about the ethical conduct of this research project, please contact the University of Ballarat Ethics Officer, Research \& Graduates Studies Office, University of Ballarat, PO Box 663, Mt Helen VIC 3353. Telephone: (03) 5327 9765, Email: ub.ethics@ballarat.edu.au

CRICOS Provider Number 00103D 


\title{
Appendix C: Consent Form
}

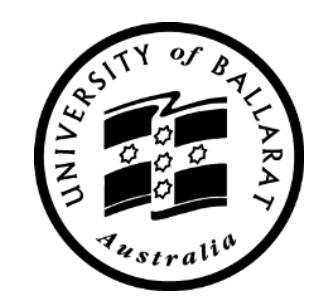

\section{UNIVERSITY OF BALLARAT}

\section{CONSENT FORM}

PROJECT TITLE: Learning through Practice: A study of work-based learning as part of VET programs in New Zealand

\section{RESEARCHERS:}

Principal Researcher: Professor Erica Smith, University of Ballarat.

Names of other Senior and Associated Researchers: James Cannan, Manukau Institute of Technology.

The University of Ballarat's in Human Research Committee has approved this research study. The Plain Language Information Statement (provided to you) gives full information about the project.

1. I understand that I am being asked to participate in a focus group or an interview.

2. I understand that I don't have to agree to the focus group or interview being taped. (If anyone in the focus group doesn't want it to be taped, we won't tape the group.)

3. I understand that I am free to withdraw my participation in the research at any time (this includes the right to have my comments removed from the focus group or interview record afterwards)

4. I understand that as the numbers in the focus group are small it could be possible for somebody to work out who made certain comments.

5. The purpose of the research has been explained to me.

6. I understand that any information or personal details gathered in the course of this research about me are confidential and that neither my name nor any other identifying information will be used or published. However it is possible that information could be obtained by somebody under the Freedom of Information legislation.

Signed

Date

\begin{abstract}
Should you (i.e. the participant) have any concerns about the ethical conduct of this research project, please contact the University of Ballarat Ethics Officer, Research \& Graduates Studies Office, University of Ballarat, PO Box 663, Mt Helen VIC 3353. Telephone: (03) 5327 9765, Email: ub.ethics@ballarat.edu.au
\end{abstract}




\section{Appendix D: Consent Form for Lecturers}

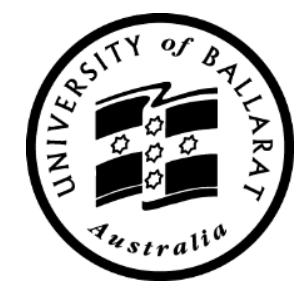

\section{UNIVERSITY OF BALLARAT}

\section{CONSENT FORM for Lecturers}

PROJECT TITLE: Learning through Practice: A study of work-based learning as part of VET programs in New Zealand

\section{RESEARCHERS:}

Principal Researcher: Professor Erica Smith, University of Ballarat. Names of other Senior and Associated Researchers: James Cannan, Manukau Institute of Technology.

The University of Ballarat's in Human Research Committee has approved this research study. The Plain Language Information Statement (provided to you) gives full information about the project.

1. I understand that I am being asked to participate in an interview.

2. I understand that I don't have to agree to the interview being taped. (If you do not wish to be recorded, we won't record the interview.)

3. I understand that I am free to withdraw my participation in the research at any time (this includes the right to have my comments removed from the interview record afterwards)

4. I understand that as the number of staff being interviewed is small, it could be possible for somebody to work out who made certain comments.

5. The purpose of the research has been explained to me.

6. I understand that any information or personal details gathered in the course of this research about me are confidential and that neither my name nor any other identifying information will be used or published. However it is possible that information could be obtained by somebody under the Freedom of Information legislation.

Signed.

Date.

Should you (i.e. the participant) have any concerns about the ethical conduct of this research project, please contact the University of Ballarat Ethics Officer, Research \& Graduates Studies Office, University of Ballarat, PO Box 663, Mt Helen VIC 3353. Telephone: (03) 5327 9765, Email: ub.ethics@ballarat.edu.au 


\section{Appendix E: Questionnaire}

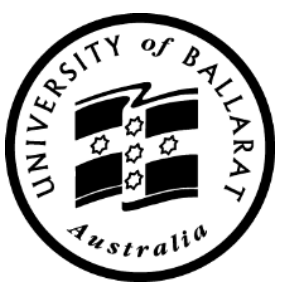

UNIVERSITY OF BALLARAT

PROJECT TITLE: Learning through Practice: A study of work-based learning as part of VET programs in New Zealand.

\section{Questionnaire questions}

1. Is your age between (A) $16-20$, (B) 21-25 or (C) 26 or older?

2. Are you a male or female student?

3. What ethnic background do you associate with?

4. What was your final year of study at School?

5. Please list any qualifications that you have achieved at School or other Tertiary studies.

6. Please state if you had any jobs before starting the course or currently working full or part time.

7. If currently working does the job relate to the current study?

8. How long have you been in an apprenticeship? (apprentices only)

9. Have you studied previously as a pre-apprentice? (apprentices only)

10. What level of training are you currently at?

11. What have you learned during your apprenticeship/pre-apprenticeship?

12. Where did you do the most learning (on-job, or off-job training)?

13. What is the expected timeframe it will you take to complete the qualification at level 4 ?

14. What is your plan for further study, and how does the apprenticeship/pre-apprenticeship fit in with this? 


\section{Appendix F: Interview Questions-Apprenticeship/Pre- apprenticeship Training}

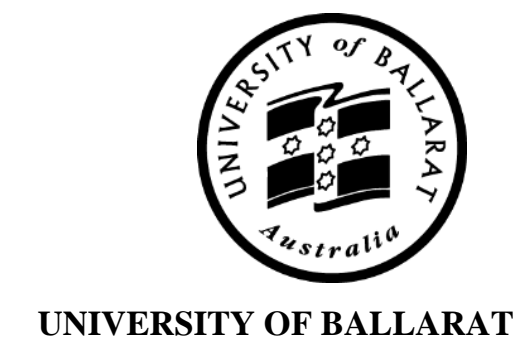

PROJECT TITLE: Learning through Practice: A study of work-based learning as part of VET programs in New Zealand.

\section{Interview questions}

\section{Apprentices/Pre-apprenticeship training}

1. What have been the most satisfying things about your apprenticeship/pre-apprenticeship training program?

2. What have been the most difficult or frustrating things about your apprenticeship/preapprenticeship training?

3. What skills do you need to be a good tradesperson? (relate to discipline)

4. Tell me about how your training in the workplace is carried out, and what you think about it?

5. Tell me about how you are assessed, and whether you think it is appropriate?

6. What do you expect will be the benefits of attending the program/course?

7. How can your program/course be improved?

8. What do you think that your strengths are in practical skills for current work requirements?

9. Are there any skills that the program has helped you develop for your future career?

10 .What additional knowledge do you need to advance your career?

11 What further thoughts do you need to consider towards positive attitudes to work/study? 


\section{Apprentices}

12. How does the off-job training work? Does it relate to what you do in your job - is it relevant? What are the good and bad things about off-job training?

13. Have you been satisfied with the training and support provided by your trainer at the Institute and by your boss during your apprenticeship at the workplace?

14. What are the key things that the trainer/boss needs to get right for quality apprenticeship training?

15. Do you think that being an apprentice is worthwhile? If yes, why? /if no, why not?

16. Are there any suggestions about how an apprenticeship might be improved - in your company, in the industry, more generally?

17. Are you able to complete all the on-job assessment requirements at the workplace? If not why not?

18. Do you get treated any differently to other workers because you are an apprentice?

19. Have you been satisfied with the training and support provided by your ITO Training Managers?

\section{Pre-apprentices}

20. Do you currently have a Part time Job? If yes, is it in the same field, or in a different field from what you are studying?

21. Is there any on-job training? If yes, how does that work? Are you given time at the workplace to study or learn from other staff? If no, how are you expected to learn about the job?

22. Have you been satisfied with the training and support provided by your trainer/boss during your pre-apprenticeship?

23. Do you think that being a pre-apprentice is worthwhile? If yes, why? /if no, why not?

24. What is the most important overall benefit you have gained from this full time program?

25. Are there any suggestions about how a pre-apprenticeship might be improved?

26. Are you able to complete all the assessment requirements? If not why not?

27. Do you think that this program will help you make the transition to the workplace? 


\section{Appendix G: Interview Questions-Employer/Workplace Supervisor}

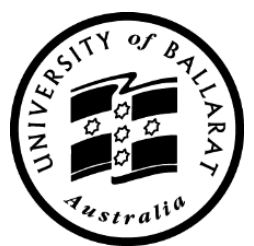

\section{UNIVERSITY OF BALLARAT}

PROJECT TITLE: Learning through Practice: A study of work-based learning as part of VET programs in New Zealand.

\section{Interview questions}

\section{Employer/work place supervisor}

1. What is your role on the pre-apprenticeship/apprenticeship course/program? Can you let me know how it is delivered?

2. What have been the most satisfying things for you as an employer involved in preapprenticeship/apprenticeship training courses? (i.e. class and practical delivery, work delivery, curriculum)

3. What have been the most difficult or frustrating things about the preapprenticeship/apprenticeship training program? (key points as q.2)

4. How are the students assessed at the workplace? Are you happy with how the students are assessed, and if not how do you think the assessment could be improved?

5. What do you expect will be the benefits for the students from attending the course/ program/?

6. What is the theory/practical ratio of the course/program? In your view is this appropriate or does it need adjusting?

7. Is there anything that you think could be improved with the course/program to benefit the students? (key points as q.2)

8. For students to meet the graduate profile are there any skills that the course/program has not addressed?

9. Is there any on-job training provided at the workplace? If yes, how does that work?

10.Do you feel that the students on the course/program are gaining enough training on the job whilst studying?

11. Do you think that pre-apprentice/apprentice training at MIT is worthwhile? If yes, why? If not, why not? (Relates to research q 3)

12.Do you think that the pre/apprenticeship program will help the students make the transition to the workplace?

13. What are your thoughts on a level 4 pre-apprenticeship program being developed at MIT? 


\section{Appendix H: Interview Questions—Staff (Apprenticeships Level}

3)

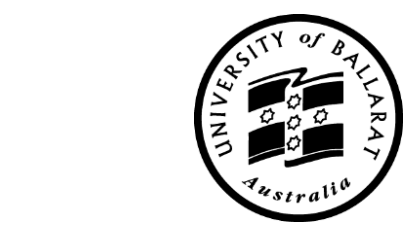

UNIVERSITY OF BALLARAT

PROJECT TITLE: Learning through Practice: A study of work-based learning as part of VET programs in New Zealand.

\section{Interview questions}

\section{Staff/apprenticeships level 3}

1. What is your role on the apprenticeship course/program? Can you let me know how it is delivered?

2. What have been the most satisfying things for you as a lecturer when delivering the level 3 apprenticeship training course? (i.e. class and practical delivery, work delivery, curriculum)

3. What have been the most difficult or frustrating things about the apprenticeship training course? (key points as q.2)

4. How are the students assessed? Are you happy with how the students are assessed, and if not how do you think the assessment could be improved?

5. What do you expect will be the benefits for the students from attending the course?

6. What is the theory/practical ratio of the course? In your view is this appropriate or does it need adjusting?

7. Is there anything that you think could be improved with the off job training course to benefit the students? (i.e. class and practical delivery, work delivery, curriculum)

8. For students to meet the meet current industry requirements are there any skills that the course has not addressed?

9. Is there any on-job training provided at the workplace? If yes, how does that work? Do you feel that the students on the course are gaining enough training on the job whilst studying?

10. Do you think that off job apprentice training is worthwhile? If yes, why? /if no, why not? (relates to research q 3)

11. Are there any suggestions about how apprenticeship training might be improved?

12. Do you think that the courses delivered by MIT will help the students achieve their qualification? ( these courses are contracted by the ITO to MIT and it is possible for students to achieve their qualification as a trainee and not as an apprentice through the ITO) 


\section{Appendix I: Interview Questions-Staff (Pre-apprenticeships)}

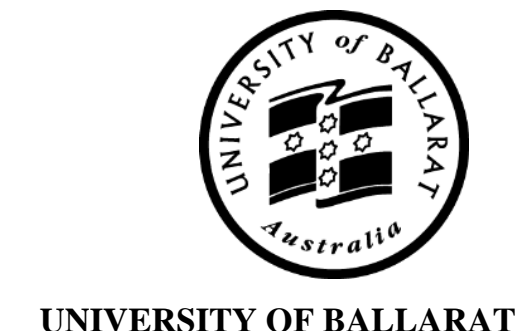

PROJECT TITLE: Learning through Practice: A study of work-based learning as part of VET programs in New Zealand.

Interview questions

\section{Staff/pre-apprenticeships}

1. What is your role on the pre-apprenticeship program? Can you let me know how it is delivered

2. What have been the most satisfying things for you as a lecturer when delivering the preapprenticeship training program? (i.e. class and practical delivery, work delivery, curriculum)

3. What have been the most difficult or frustrating things about the pre-apprenticeship training program? (key points as q.2)

4. How are the students assessed? Are you happy with how the students are assessed, and if not how do you think the assessment could be improved?

5. What do you expect will be the benefits for the students from attending the program/?

6. What is the theory/practical ratio of the program? In your view is this appropriate or does it need adjusting?

7. Is there anything that you think could be improved with the program/course to benefit the students? (key points as q.2)

8. For students to meet the graduate profile are there any skills that the course/program has not addressed?

9. Is there any on-job training provided at the workplace? If yes, how does that work? Do you feel that the students on the program are gaining enough training on the job whilst studying?

10. Do you think that pre-apprentice training is worthwhile? If yes, why? /if no, why not? (relates to research q 3)

11. Are there any suggestions about how a pre-apprenticeship might be improved?

12. Do you think that this program will help the students make the transition to the workplace?

13. What are your thoughts on a level 4 pre-apprenticeship program being developed at MIT? 


\section{Appendix J: Advanced Study Units}

I commenced study on the Doctor of Education (EdD) program in June 2008 and the first advanced study unit covered TM948 Vocational Education \& Training. This study unit required the completion of three assignments; the first assignment was an essay on the main features of New Zealand's economy, society and labour market that impact on VET and higher education provision. This paper was completed on time on 20 July 2008.The second assignment was an essay titled: Describe the VET sector in New Zealand and compare and contrast it with at least one other country's VET sector. This paper was completed on time on 20 September 2008. The third assignment was an essay titled: Describe why, and the ways in which, VET courses incorporate workplace experiences. What delivery and assessment issues arise as a result of the different models of incorporation? This paper was completed on time on 30 November 2008.

The second advanced study unit I completed was TM941 Ways of Researching (Advanced). The first part of this was work based on two distance learning modules and the first assignment was to complete all the study tasks for the Title Module 1 Research in VET. The first module consisted of two topics that covered the evaluation and the utilisation of research and the learning outcomes met were to: demonstrate ability to describe and discuss evaluation theory, and the second was to: demonstrate an understanding of the roles of evaluation and research in VET. This was completed on time on 19 June 2009.

The second module consisted of ERP440 Module 2: Research in VET and the module contained six topics that covered the research process including: Thinking about and managing research, Ethics and research, The research proposal, Researching and presenting the literature, Deciding on research methods (quantitative and qualitative), Analysing and presenting research data, Writing up and presenting the results, and Acting on the results. All learning activities were completed by 24 July 2009. The final requirement of the second advanced study was a written essay discussing the different ways in which the research project could be researched and the pros and cons of each. A justification for the methods preferred was described and the essay was completed on time on 21 August 2009. 
The third advanced study unit was based on Unit EDMED7038 Analysis and Inquiry: Reading and Framing the Research. Two main objectives of this unit were to firstly provide a framework for students to investigate a topic of their choice at an advanced level and the second was to understand the importance of the literature review in academic work. The first assignment required an overview of a literature review and a presentation to colleagues covering proposed research questions, proposed research methods, names of four to eight bodies of literature relating to the research questions, and how the literature related to the research questions and a number of references focusing on the relevance to the research questions. This work was completed on time on 8 March 2010. The second assignment in this unit was to submit a full literature review for the proposed research study of 5,000 words, with between 70 and 100 items of literature. This work was duly completed and handed in on 28 May 2010. 